\title{
School Climate, Early Adolescent Development, and Identity: Associations with Adjustment Outcomes
}

\author{
Megan Lorraine Smith
}

Follow this and additional works at: https://researchrepository.wvu.edu/etd

\section{Recommended Citation}

Smith, Megan Lorraine, "School Climate, Early Adolescent Development, and Identity: Associations with Adjustment Outcomes" (2015). Graduate Theses, Dissertations, and Problem Reports. 6670.

https://researchrepository.wvu.edu/etd/6670

This Dissertation is protected by copyright and/or related rights. It has been brought to you by the The Research Repository @ WVU with permission from the rights-holder(s). You are free to use this Dissertation in any way that is permitted by the copyright and related rights legislation that applies to your use. For other uses you must obtain permission from the rights-holder(s) directly, unless additional rights are indicated by a Creative Commons license in the record and/ or on the work itself. This Dissertation has been accepted for inclusion in WVU Graduate Theses, Dissertations, and Problem Reports collection by an authorized administrator of The Research Repository @ WVU.

For more information, please contact researchrepository@mail.wvu.edu. 
School Climate, Early Adolescent Development, and Identity: Associations with Adjustment Outcomes

Megan Lorraine Smith

Dissertation submitted

to the College of Education and Human Services

at West Virginia University

in partial fulfillment of the requirements for the degree of

Doctor of Philosophy in

Human Development and Family Studies;

Interdisciplinary Education

Carol Markstrom, Ph.D., Chair

Alfgeir Kristjansson, Ph.D.

Amy Root, Ph.D.

Jessica Troilo, Ph.D.

Reagan Curtis, Ph.D.

Department of Learning Sciences and Human Development

Morgantown, West Virginia University

2015

Key words: Early adolescent development, school climate, Self Determination Theory, risk behavior

Copyright 2015 Megan Smith 


\section{Abstract \\ School Climate, Early Adolescent Development, and Identity: Associations with Adjustment Outcomes \\ Megan Smith}

Early adolescence is a time of risk and exploration for young people. In a period of development marked by increasing independence, young people are still learning the skills necessary for success in their adult lives. Positive development is impacted not only by individual characteristics, but also by the environments and social supports present. Adolescents spend a significant amount of time in schools, thus schools are an important context to study in regards to positive adolescent outcomes. Self Determination Theory (SDT, Deci \& Ryan, 2000) posits that the degree to which an individual's basic psychological needs for autonomy, competence, and relatedness are satisfied impacts an individual's positive developmental outcomes. More recent work on SDT (LaGuardia \& Ryan, 2002) posits that this process works through identity development. The present study sought to investigate this theory within the middle school context. Students enrolled in three West Virginia middle schools $(n=1,130)$ participated in this survey research study. Data were analyzed primarily used Hierarchical Multiple Regression and Structural Equation Modeling (SEM) to test SDT and to more deeply understand the associations between key study variables (school climate, adolescent development, identity formation, and adjustment outcomes). Findings support the notion that both general adolescent developmental support as well as school climate contribute significantly to positive identity development which, in turn, supports healthy adjustment outcomes including less substance abuse and sexual risk, and higher academic achievement. Thus, schools should work to support individuals' basic psychological needs as well as identity development. 


\section{Acknowledgments}

I would like to begin by thanking my chair, Dr. Carol Markstrom, I am grateful to her for taking me on as student and working patiently with me over the past three years. Her ability to pursue her passions and to excel in such endeavors is truly inspirational. Next, I'd like to thank Drs. Amy Root and Jessica Troilo, my dissertation would not be what it is today without their guidance and immense effort in challenging my work to be better. I would also like to think Dr. Alfgeir Kristjansson for including me in the ICE Collaborative and for being a solid mentor who was always willing to share the realities of the academic world with me. Additionally, gratitude is due to my mentor, supervisor, teacher, and committee member, Dr. Reagan Curtis. I will forever be grateful for his offer to be part of the Program Evaluation and Research Center team. It is through this position, and his careful guidance, that I gained the research and professional skills necessary to be a thriving member of the academic community. Finally, I would like to thank my family and friends who have always been incredibly supportive and positive throughout my journey. Most of all, I'd like to thank my daughter, Lydia Rose, who shared the first years of her life with mommy's dissertation, and her incredible father who I am fortunate to call my husband; he is wise, kind, and generous and I will forever be grateful for his unconditional support. 
Table of Contents

List of Tables ..................................................................................................... vi

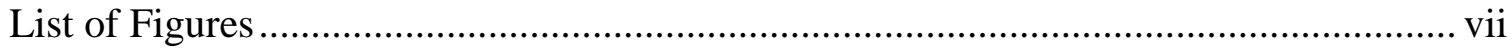

Chapter 1: Introduction to the Study .......................................................................... 1

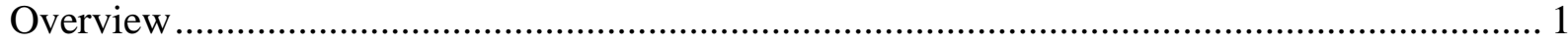

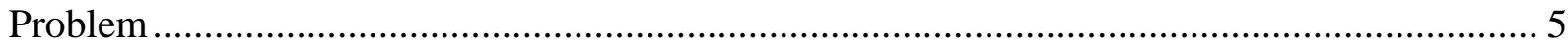

Purpose

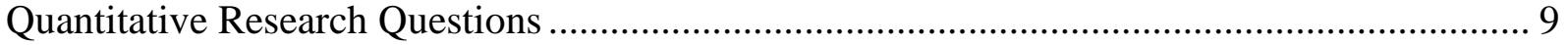

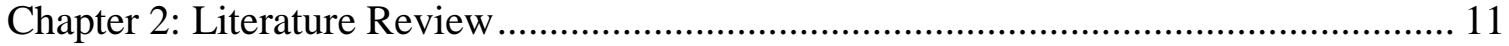

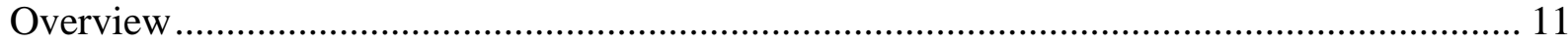

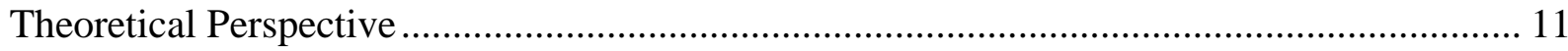

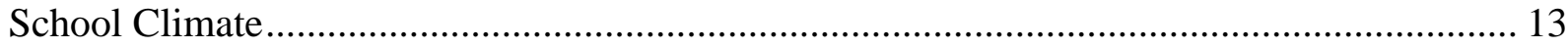

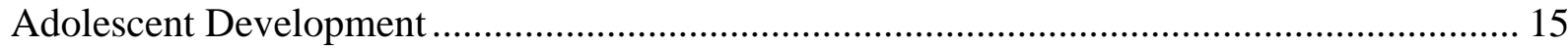

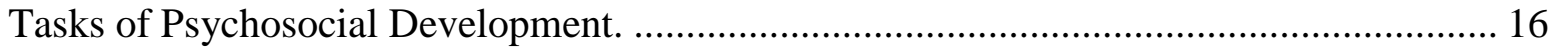

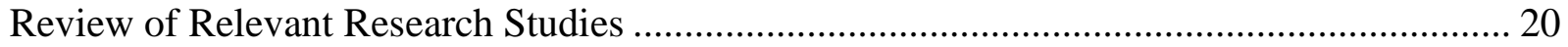

School climate and basic psychological needs satisfaction. ......................................... 20

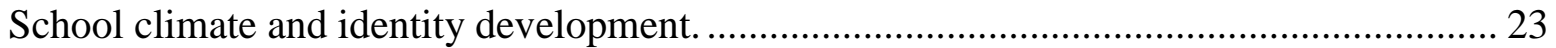

Adolescent development and identity development. ............................................... 26

Adjustment Outcome Variables ................................................................................... 28

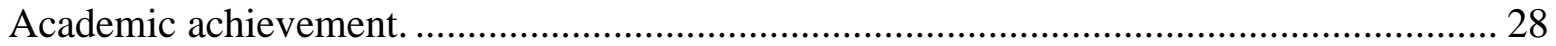

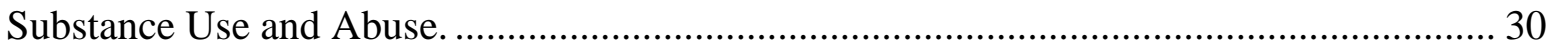

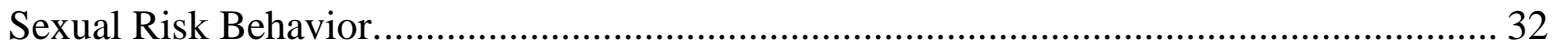

Quantitative Research Questions with Associated Hypotheses .......................................... 34

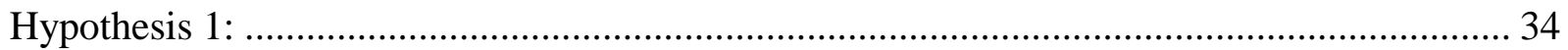

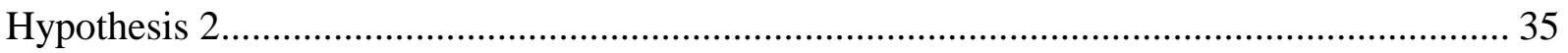

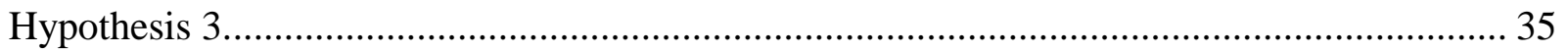

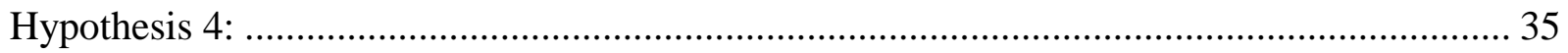

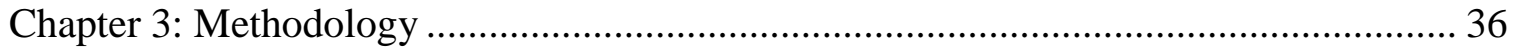

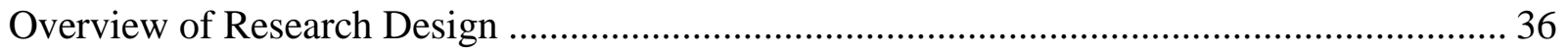

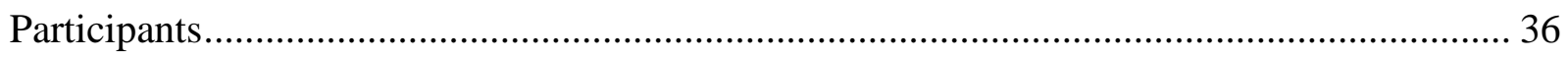

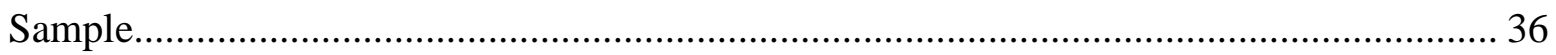

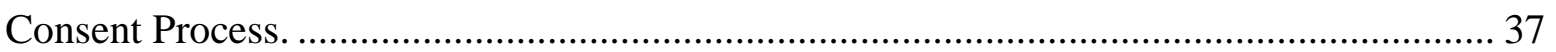

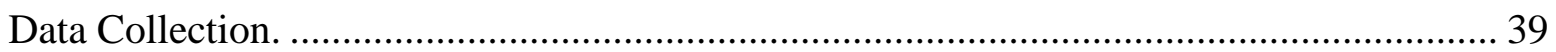




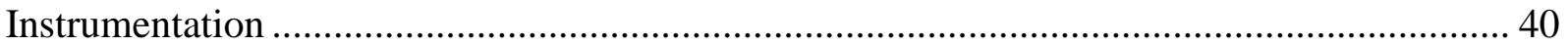

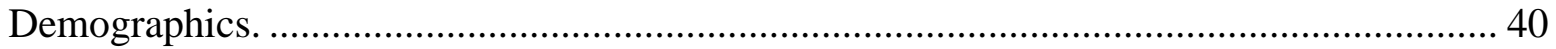

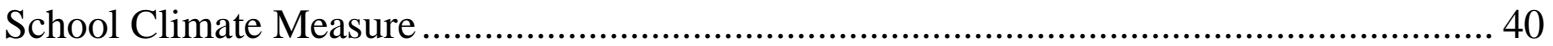

Basic Psychological Needs Satisfaction Measure.................................................................. 41

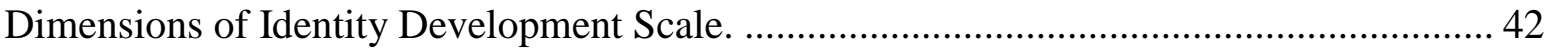

Rates and Incidence of Health Behaviors associated with Adjustment Outcomes............... 43

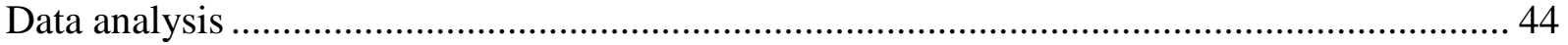

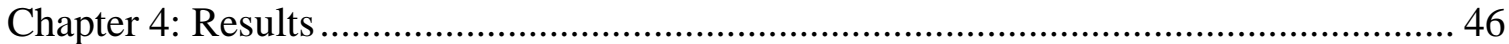

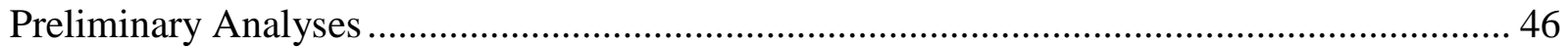

Bivariate Correlations between Study Variables (See Appendix D, Table D2)................... 46

Research Question \#1: What is the pattern of association between School Climate and

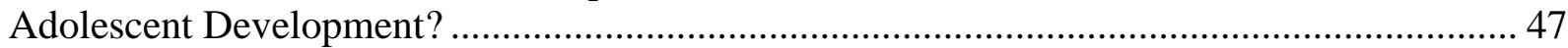

Research Question \#2: How are school climate and adolescent development associated with identity development?

Research Question \#3: What are the relations between the latent constructs in the hypothesized model and how do they affect adjustment outcomes? ........................................................... 48

Research Question \#4: Are the effects of School Climate and Adolescent Development on adjustment outcomes mediated by Identity Development?

Chapter 5: Discussion 54

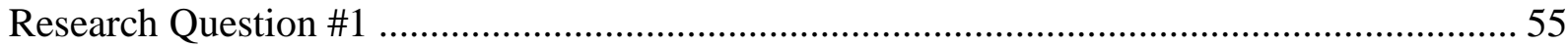

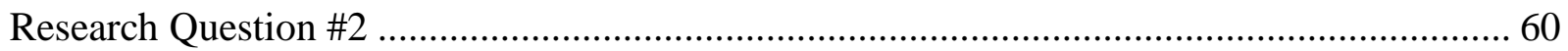

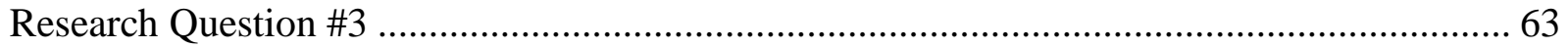

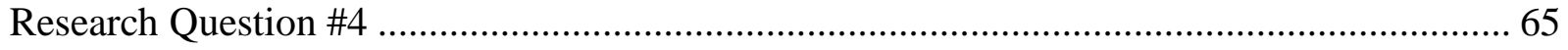

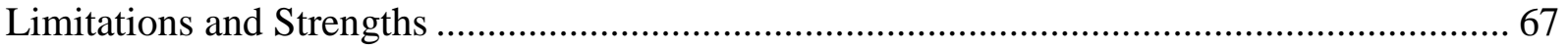

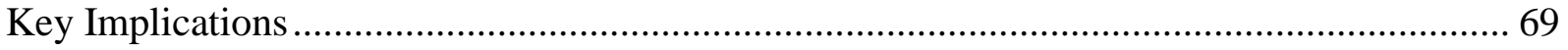

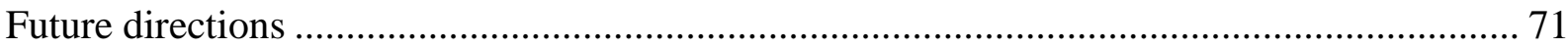

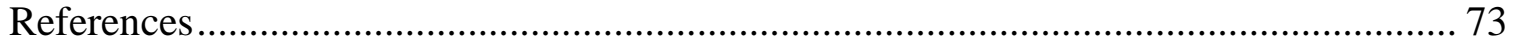

Appendix A: Figures to support the present study........................................................ 98

Appendix B: Assent and consent letters and IRB Approval......................................... 100

Appendix C: Measures used in the current study …………........................................ 103

Appendix D: Additional Tables and Figures ............................................................ 136

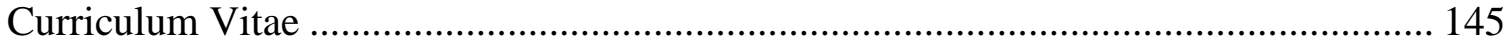




\section{List of Tables}

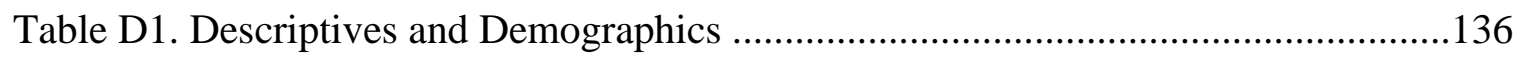

Table D2. Bivariate Correlations of Study Variables ................................................137

Table D3. Regression model; school climate factors on adolescent development ..........139

Table D4. Regression model; school climate and adolescent development on identity ..140

Table D5. Confirmatory factor analysis of latent variables in model .............................141 


\section{List of Figures}

Figure A1. Bronfenbrenner's Ecological Development Model .................................... 98

Figure A2. Diagram of the mediation model ..................................................... 99

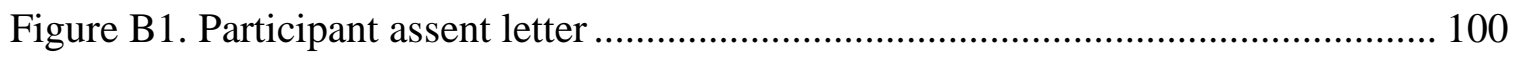

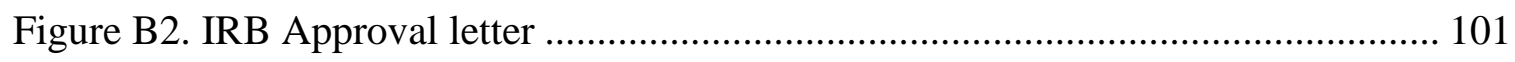

Figure B3. Parental passive consent letter ........................................................ 102

Figure C1. The School Climate Measure ................................................................ 103

Figure C2. Basic Psychological Needs Satisfaction ................................................ 105

Figure C3. The Dimensions of Identity Development .......................................... 106

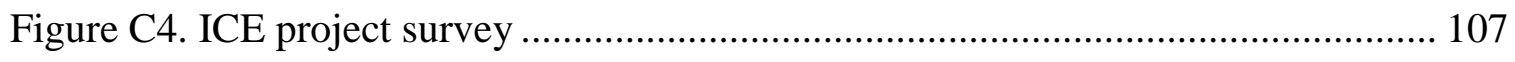

Figure D6. Structural model on academic achievement ........................................ 142

Figure D7. Structural model on substance use................................................... 143

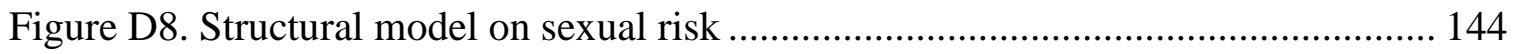


"Early experiences rarely make or break us. Instead there are opportunities throughout life to undo much of the damage done by early traumas, teach new skills, and redirect young lives along more fruitful pathways," (Shaffer, 2009, p.493).

\section{Chapter 1: Introduction to the Study}

\section{Overview}

In contemporary American society most adolescents face challenges to their healthy growth and development. Such challenges range from normative experiences like navigating changing peer or parent relationships, to more extreme, high risk challenges like experiencing violence, sexual abuse, or other threats to their emotional or physical health. All of this comes at a particularly vulnerable period in their development. Adolescent's brains are still developing problem-solving and coping abilities during this period marked by heightened responsibilities, increased independence, and increased expectations (Steinberg, 2008). For some, this time period is also marked by diminished self-confidence and esteem (Harter, 1999). Although the majority of adolescents successfully make it through this time of risk and exploration and grow into well-adjusted adults (Arnett, 1999; Larson, 2000), all adolescents benefit from safe and supportive environments designed to meet their developmental needs. Uri Bronfenbrenner (1979, 1989) asserted that individuals do not develop separate from their contextual settings. In his ecological systems model (Figure A1), Bronfenbrenner outlines the different aspects of an environment that have a multitude of bidirectional interactions with an individual. According to adolescent researchers like McMahan (2009), adolescents develop within four main contexts: families, peers, culture, and schools. 
In the best of scenarios, the ideal purpose of schools is to create a positive and engaging environment that works as a foundation and catalyst for the healthy development of all students. Much like the ideas of great educational philosophers such as Socrates, Dewey, and Freire, schools should not be factories where irrelevant and standardized information is input into students' brains (Dewey, 1916, 1933, 1938; Friere, 1986; Plato \& Jowett, 1941). More modern researchers such as Roeser, Eccles, and Sameroff (2000) and Steinberg (1996) suggest that formal education in America should focus on healthy development of the whole adolescent, rather than just cognitive skills. In other words, schools should create opportunities for all students to develop to their fullest ability. Schools have great potential for providing opportunities to students for exploration, warm interpersonal connections, and intellectual stimulation in order to foster their growth into their best possible selves. Currently, the typical American student spends 6 hours a day, 182 days a year for 14 years in school; the equivalent of 15,288 hours. Given the amount of time spent, and the stated purpose of American education, defined as creating the "foundation of a strong future and a strong society" (Duncan, 2009, p. 3), there is no question, that when done right, school environments can contribute to and support the healthy development of students. The current study contributes to existing literature by studying adolescent development and associated adjustment outcomes in combination with the potential impact of school contextual factors.

Conceptualizing what makes a good school and how that relates to healthy adolescent development is a daunting task. Self Determination Theory (SDT) states that environments that meet the basic psychological needs of individuals contribute to their intrinsic motivation to make positive life choices (Deci \& Ryan, 1985). Individuals are stated to be naturally oriented towards growth and development and that this orientation is inspired and sustained by the fulfillment of 
psychological needs for autonomy, competence, and relatedness (Deci \& Ryan, 1985). SDT asserts that whereas individuals are generally intrinsically motivated to participate in novel and satisfying activities that promote positive healthy development, not all behaviors and activities are intrinsically motivated (Ryan \& Deci, 2000). Therefore, SDT suggests that some unenjoyable, but developmentally conducive, behaviors (such as attending school or work each day) need to be socialized in such a way that individuals eventually internalize these previously extrinsically motivated behaviors (Ryan, Deci, \& Grolnick, 1995).

SDT outlines three basic psychological needs that should be met in order for effective internalization and psychological development (Deci \& Ryan, 2000). These basic psychological needs include: (a) autonomy, or the sense that one has choice and personal control over ones outcomes, (b) competence, the sense of one's efficacy in accomplishing what one desires, and (c) relatedness, the presence of warm and caring relationships/interactions with others (Deci \& Ryan, 1985). This theory relates to the current study because schools, in order to support healthy development, should provide for these basic psychological needs. Based upon these ideas, it seems possible that positive school environments that foster autonomy, competence, and relatedness will provide greater opportunity for healthy development.

One possible oversight of early SDT theory was the lack of inclusion of identity formation because it is widely recognized as a component of optimal adolescent development (Luyckx, Vansteenkiste, Goossens, \& Duriez, 2009). Erik Erikson (1968) conceptualized identity formation as a key task of development over the lifespan. Identity is the extent to which an individual knows who he or she is in the world. It is constructed through an individual's exploration of his or her environment (Erikson, 1959, 1968). Through this exploration, an individual makes decisions about the activities, people, and choices that "fit" his or her sense of 
self. At the adolescent stage, identity development becomes a particularly salient task because individuals' brains develop to allow them to consider different, hypothetical ways of being. Furthermore, social influences and expectations change and allow adolescents a "new array of choices and decisions" (Steinberg, 2008, p. 269). Achieved identity is our relatively static sense of self, based on a thorough exploration of the different possibilities for one's self (Marcia, 1966). Research has shown strong relations between healthy identity formation and positive developmental outcomes (Eichas, Mecca, Montgomery, \& Kurtines, 2014; Larson, 2000). These outcomes include positive self-concept, self-esteem, and psychological well-being, (Kroger, 2008) and agency (Côté, 2000). Thus, identity may have the ability to cement the effects of one's basic psychological needs satisfaction in autonomy, competency, and relatedness. The more an individual's needs are met by his or her environments, the more he or she may build a positive identity and choose behaviors that align with such an identity.

One significant predictor of positive development over the lifespan is academic attainment or success (Bausch, 2010; Jessor \& Jessor, 1977). In fact, the notion of the positive impact of academic success on individual outcomes is perhaps so pervasive that it is widely regarded as fact (Bausch, 2010). Academic achievement has been linked to a multitude of positive adjustment outcomes for individuals including increased physical health (Carlson et al., 2008; CDC, 2010; Srabstein \& Piazza, 2008; Spriggs \& Halpern, 2008), mental health (Asarnow et al., 2005), social emotional competence (Masten et al., 2005; Roeser, Eccles, \& Sameroff, 2000), economic well-being (Bausch, 2010) decreased risk factors such as high school drop-out (Eggert, Thompson, Herting, Nicholas, \& Dicker, 1994) and early sexual activity or pregnancy (CDC, 2014b). Thus, it is incredibly important to understand how environments and psychological needs satisfaction can encourage behaviors that lead to academic attainment and 
success in order to promote the healthy growth and development of individuals to their fullest potential.

Based on the theory and research presented above, positive school climate, in conjunction with the satisfaction of basic psychological needs, can contribute to positive identity formation, which in turn can influence an individual's positive adjustment.

\section{Problem}

In contemporary American society, adolescents face many challenges. Families are not always willing or able to provide a strong foundation for meeting the basic developmental needs of young people. Thus it is important for schools to have the tools to provide support for this process. Even when adolescents do have positive family support at home, educational systems should be developmentally responsive to the basic psychological needs of the young people they serve. Unfortunately, not all school environments are developmentally advantageous for students. Continued accounts of school drop-out rates, teen parenting, substance abuse, bullying, suicide, and other school violence provide evidence that schools could be doing a better job supporting adolescents' development.

At particular risk, are the relatively under studied early adolescent population. Young people between the ages of 11-15 are often grouped in with studies that focus on elementaryaged students or high school-aged adolescents. Yet, developmental researchers know that early adolescence is a unique time of development (Steinberg, 2008). Early adolescence, like the integral developmental time period of birth to three years old, is the only other time marked by a period of heightened synaptic pruning and rapid brain change. In fact, by mid-adolescence brain systems involved in all basic cognitive functions have already reached adult-level maturity (Steinberg, 2014), suggesting that early adolescence may be a very important time to focus our 
efforts on supporting young individuals' healthy development. Early adolescents are more rapidly gaining the necessary skills, cognitively, physically, emotionally and socially, to become autonomous and fully developed persons. Young adolescents' middle school outcomes often predict negative high school and later life outcomes such as academic performance, drop-out rates and risk behaviors (Henry, Knight, \& Thornberry, 2012). If ignored, middle school students' needs can lead to long-lasting poor choices that affect both the student and the society in which they live.

Further complicating this issue is that many American students transition from elementary school to middle school at this stage, creating an even more tumultuous time for many adolescents (Eccles et al., 1993; Parker, 2009). Additionally, peers become more present in the lives of young adolescents and they begin to re-define themselves by the young people they come into contact with (Deater-Deckard, 2001; Osterman, 2000). The growing significance of peers is important to recognize because peers can augment or disadvantage the emotional and physical well-being of a child. They may act as protective factors or encourage risk behavior. It is therefore arguable that supporting young people at a middle school may lead to a pervasive developmentally positive school climate. Young adolescents have a dynamic sense of self as they seek to build their identity. As they begin "trying on" different elements of what will make them individual they can sometimes baffle adults. Early adolescents show a fierce sense of independence, but simultaneously seek meaningful adult relationships; they are beginning to be more cognitively capable, but often have trouble articulating their less organized thoughts; and they can be motivated by true goodness at the same time they are capable of unusual cruelty and judgment against others (San Antonio, 2006). Because of this seemingly contradictory behavior, 
young adolescents are dismissed as "awkward" or in "a phase" with no concern to the long term effects of the issues they face.

Finally, this age group is important to support because recent research on brain development has shown that the prefrontal cortex, which is involved with planning, impulse control, reasoning and executing actions, is not fully developed during early adolescence (Powell, 2006). Secretion of adrenal sex hormones increases which leads to adolescents seeking intense experience, through interpersonal connections or risk taking behaviors (Wallis \& Park, 2004). Current research looked at the effects of negative life events on early adolescents (as compared to older adolescents and young adults) and found that events effected them more intensely (Mann, Kristjansson, Sigfusdottir, \& Smith, 2013).. For this young adolescent population events were also less differentiated; the "worst thing that ever happened" to these students was the worst thing that ever happened; so, things like doing poorly on a quiz were felt similarly to losing a loved-one (Mann et al., 2013). In summation, early adolescents are seeking hormone-driven emotional experiences at a time when their emotions are heightened, yet their brains are not fully capable of exercising judgment, impulse control, or coping mechanisms to help them through such challenges.

It seems, then, that research paints a clear picture of the "battles" middle school-aged children are facing on multiple fronts. Middle schools are in an excellent position to help support these students. Well prepared middle school teachers, armed with the tools to support this challenging developmental period, can be highly effective in creating developmentally positive environments for young adolescents. If positive school environments have the potential to support the fulfillment of basic developmental needs (autonomy, competency, and relatedness,), 
which in turn leads to positive identity that foster behaviors that lead to positive adjustment, then pursuing this research area becomes a unquestionably justifiable pursuit.

\section{Purpose}

School climate, often referred to as "culture" or "environment," has been described and redefined for over a century (Zullig, Koopman, Patton, \& Ubbes, 2010). Whereas many studies point to positive outcomes as associated with positively defined school climate, very few of them look at school environments as developmental contexts in relationship to basic psychological needs fulfillment and their potential to protect students from potentially detrimental risk behaviors. Because schools have a unique opportunity to help adolescents develop into healthy competent individuals, it seems pertinent to explore the relationships between a person's school environment, the extent to which their psychological needs are being met, and the behaviors that support academic success.

Extent literature provides a strong case for the fact that development is influenced by culture, historical context, parents, peers, and other community influences such as schools (Bronfenbrenner, 1994). Further, development often follows general trajectories and evolves in response to changing environmental factors (Shaffer, 2009; Steinberg, 2008). According to Steinberg (2008), there are four key processes integral to healthy adolescent development. These processes are identity, autonomy, competency/achievement, and interpersonal relationships. These four processes create the challenges and fortifications that result in an individual making it "through" adolescence into healthy adulthood. School environments should provide avenues for students to develop autonomy, competency, relationships, and identity. The purpose of this study is to examine the associations between school climate, basic psychological needs fulfillment, identity formation, and healthy adjustment outcomes. This study will contribute to 
the professional literature by describing this relationship and discussing the implications of schools as a developmental environment. This study also contributes to the literature by focusing on a relatively understudied population, early adolescents. (particularly at the school level see National Center for Educational Statistics, 2015).

\section{Quantitative Research Questions}

1) What is the pattern of association between school climate and adolescent development?

2) How are school climate and adolescent development associated with Identity Development?

3) What are the relations between the latent constructs in the hypothesized model and how do they affect adjustment outcomes?

4) Are the effects of school climate and adolescent development on adjustment outcomes mediated by identity development?

\section{Summary}

Children and adolescents spend a tremendous amount of time in schools. School environments have a rich potential to positively impact students' developmental outcomes by meeting their basic psychological needs. In meeting an individual's need for autonomy, competency, relatedness, and in supporting a student's positive identity formation, schools may impact a student's developmental trajectory. The current study makes the supposition that students who are part of positive school environments, who have their basic psychological needs satisfied, are more likely to form a positive sense of identity which will lead them to choose positive behaviors and will make them less likely to be at risk for academic failure, substance abuse, or sexual risk behavior. Thus, investigating the relationships between these constructs is an essential step for research in the fields of education and adolescent development. In spite of 
the possibilities for using schools as sites for intervention, very little research has investigated how schools may actually contribute to fostering positive development for the students they serve (Stornes, Bru, \& Idsoe, 2008). The current study endeavors to fill this gap by further clarifying the nature of the relationships between school environment, basic psychological needs fulfillment, identity development, and positive behavior choices that support healthy adjustment outcomes. This study also contributes to existing research by focusing on a relatively understudied population, early adolescents. Finally, the current study contributes to existing research because it was designed to include both existing developmental and educational research. By working across both disciplines, the current study contributes to furthering the shared pursuit of supporting the needs of young people so they may reach their full potential. 


\section{Chapter 2: Literature Review}

\section{Overview}

The primary goal of this study is to further understand the complex relations between school climate, adolescent development, identity development, and adjustment outcomes relevant to teens. The literature review begins by presenting the theoretical perspective and conceptual framework employed in this study. Next, each major construct in the study are defined. The literature review then outlines existing empirical work on school climate associations with adolescent development. Then, it outlines how school climate and adolescent development have been associated with identity development. Finally, research linking the independent variables and mediator variable to the outcome variables (adjustment, as measured by: academic achievement, substance use, and sexual risk factors) are reviewed. The last section of this chapter is a summary of the literature review in which hypotheses related to the purpose of this study are generated and presented.

\section{Theoretical Perspective}

Adolescent physical, cognitive, and emotional development occurs within social contexts, including families, friends, culture/media, and schools (McMahan, 2009; Bronfenbrenner, 1989). Therefore, understanding the nature of development necessitates understanding the social contexts in which it occurs. Self-Determination Theory (Deci, 1975; Deci \& Ryan, 1985; Ryan \& Deci, 2000) is a useful theory when endeavoring to understand the ways in which school climate might potentially interact with adolescent and identity development.

Self-Determination Theory (SDT) was originally conceptualized and researched by Deci and Ryan (1985), but over the years the theory has been refined and tested by a wealth of researchers. SDT theory suggests that individuals are naturally oriented towards growth and 
development and that this is inspired and sustained by the fulfillment of psychological needs for autonomy, competence, and relatedness (Deci \& Ryan, 1985). SDT asserts that whereas individuals are generally intrinsically motivated to participate in novel and satisfying activities that promote positive healthy development, not all behaviors and activities are intrinsically motivated (Ryan \& Deci, 2000). Therefore, SDT suggests that some less enjoyable, but developmentally conducive behaviors (such as attending school or work each day), need to be socialized in such a way that individuals eventually internalize these previously extrinsically motivated behaviors (Ryan, Deci, Grolnick, \& La Guardia, 2006). SDT outlines three basic psychological needs that should be met in order for effective internalization and psychological development (Deci \& Ryan, 2000). These basic psychological needs include: (a) autonomy; or the sense that one has choice and personal control over one's outcomes, (b) competence; the sense of one's efficacy in accomplishing what one desires, and (c) relatedness; the presence of warm and caring relationships/interactions with others (Deci \& Ryan, 1985).

Over the years, as Self Determination Theory was refined, several associations that directly relate to the conceptual model in the current study were outlined within the scope of the theory: 1) Individuals are active agents in their development, 2) Contexts provide the necessary support (or not) for the basic psychological and developmental needs of individuals, 3) The satisfaction of the need for autonomy, competency, and relatedness results from the support provided for these constructs, and 4) A person's sense of self (or identity) is either created based on intrinsic, "integrated" (positive, healthy identity development) or extrinsic, "introjected" (negative, maladaptive identity development) ways based on the extent to which his or her needs are satisfied (La Guardia \& Ryan, 2002). The current study proposes a conceptual framework that builds on this theory by introducing ego identity theory (Erikson, 1968; Marcia, 1966). Ego 
Identity theory makes the case that positive developmental (or adjustment) outcomes are often the result of an "achieved" identity status, characterized by high exploration of and high commitment to one's sense of self.

The theories above contribute to the conceptual model proposed in the current study. Based on the theoretical framework this study asserts that schools, in order to support healthy development, have the ability to provide for the basic psychological needs; autonomy, competence, and relatedness in young people. The current study further posits that when school climate is positive and adolescents' developmental needs are met, positive identity development is more likely to occur, thus promoting more positive choices and discouraging risk behavior leading to healthy adjustment. The following section defines each of the key variables included in the study.

\section{School Climate}

The school contextual environment, often referred to as school climate, has the potential to support adolescent development. According to the National Council on School Climate (NCSC, 2013), school climate is comprised of four factors: (a) safety (including physical climate and rules and norms), (b) institutional environment (including whether or not students feel they matter and are engaged in the community), (c) relationship (including with teachers and peers), and (d) teaching \& learning (including rigorous and inclusive instruction). According to Hoy (2014), "climate is to an organization what personality is to an individual." Hoy and Miskel (2014) further define school climate as "relatively enduring [...and] is experienced by participants, affects their behavior, and is based on their collective perceptions of behavior in schools.” In other words, school climate impacts all participants (teachers, administrators, students, etc.) and is based on the collection of perceptions about the school's various aspects. 
Since the late 1990's, school climate has been studied in relationship to a myriad of outcomes including attachment, connectedness and engagement (Libbey, 2004), internalizing and externalizing behaviors (Coker \& Borders, 2001; Gottfredson, Gottfredson, Payne, \& Gottfredson, 2005), and achievement (Hoy \& Hannum, 1997). Researchers have found evidence that youth thrive in positive school climates and tend to experience more positive outcomes, including academic success (Ma \& Klinger, 2000; MacNeil, Prater, \& Busch, 2009; Stewart, 2008). The National School Climate Council (NSCC, 2013) states "positive school climate fosters youth development and learning necessary for a productive, contributive, and satisfying life in a democratic society. This climate includes norms, values, and expectations that support people feeling socially, emotionally and physically safe. People are engaged and respected" (p.4). In other words, school climate encompasses the many dimensions of the school context including values and norms, relationships, physical structures and safety, teaching, and learning, and this collective sense of the climate has an enduring impact on the life satisfaction and citizenship of its participants.

The school climate, or context, "exerts a tremendous impact on the nature and outcome of the [developmental] process" (Steinberg, 2008, p. 284). Context refers to the social systems that guide both individual and collective behavior, including within schools (Choi, 2003). In fact, youths who bond to prosocial institutions are less likely to have negative developmental outcomes, including negative peer influence (Hawkins \& Weis, 1985). Goodenow (1992) firmly asserts that education and development exist so deeply ingrained within social contexts, that they are impossible to understand without considering both together. Thus, it is necessary to study adolescent development within the school climate context. 


\section{Adolescent Development}

Adolescence is part biological occurrence (considering physical, hormonal changes) and part social construction, as researchers have shown that the roles associated with and definitions of adolescence change according to the culture and history (Arnett, 2000). The concept of adolescence has changed throughout history as the expectations of youth as a workforce have changed, and adolescents are expected to remain in school at least through high school (and often college), so has the final boundary of adolescence (Arnett, 2013). Santrock (2011) defines adolescence as the developmental period between childhood and adulthood. Adolescent development consists of fundamental changes biologically (physical), cognitively (thought, intelligence, language) and socially (relationships, emotions, and personality). Due, in part, to the changes that puberty and teen exploration bring, it was a common assumption that this period in development was one of "storm and stress" (Hall, 1904). However, Arnett (1999), and other researchers have shown that, for the most part, individuals seem to have relatively smooth transitions from childhood to adulthood.

Adolescent development researchers such as Kohlberg (1966, 1981) and Gilligan (1982) have shown that adolescents are cognitively different from who they were as children because they have an increasing capacity for empathy and perspective-taking. Thus, this more prosocial disposition makes interpersonal relationships a more sought after, and yet, complex process as they begin to look at people and elements of the environment from multiple perspectives (Eisenberg, Morris, McDaniel, \& Spinrad, 2009). This particular study will focus on the four tasks of adolescent psychosocial development, which consists of four important and intertwined tasks, including autonomy, competence, interpersonal relationships, and identity (Steinberg, 2008). Existing theory and measurement exist separately for autonomy, competence, and 
relatedness (i.e. Self Determination Theory, for an example see: Deci \& Ryan, 2000) and identity (i.e. formation, for an example see Marcia, 1966; Luyckx, Goosens, Soenens, \& Beyers, 2006; Luyckx, et al., 2007).

Tasks of Psychosocial Development. Although there is not a full consensus on all the factors that encompass adolescent development, prominent developmental researchers include the following tasks, as outlined in Steinberg's (2008) Adolescence, as important to the psychosocial development during adolescence. The next sections will summarize research on these developmental tasks: autonomy, competency, relatedness and identity formation.

Autonomy. Autonomy, like identity formation, is a "psychosocial concern that surfaces and resurfaces during the entire life cycle" (Steinberg, 2008, p. 303). However, as young people reach adolescence, the physical, cognitive and social changes that accompany this stage are perfect for developing autonomy. Autonomy is a person's sense of their ability to make independent decisions that responsibly meet their needs. There are three types of autonomy; emotional, behavioral, and value autonomy. Noom, Dekovic, and Meeus (2001) describe those who have achieved a sense of autonomy as "people who gather good people around them and can rely on themselves rather than being fully supported by others, people who can weigh pros and cons despite outside pressures and people who have a strong sense of what they believe in" (as quoted in Steinberg, 2008, p. 304). Autonomy is separate from, yet often confused with, independence (Ryan \& Lynch, 1989). Autonomy is the ability to take action based on one's own thinking. The opposite of autonomy is heteronomy, not dependence (Ryan \& Solky,1996). In other words, autonomy does not mean one does not rely on others, rather it means one has the freedom to rely on others or self to make important decisions and take actions depending on their own choices. By making an effort to understand and support an adolescent's perspective and 
trying not to exert too much control over an adolescent's actions or feelings, a professional can support an adolescent's basic need for autonomy.

Competency. Similar to the importance of developing one's sense of autonomy, individuals need to feel a sense of achievement or ability, otherwise known as competency. Deci and Ryan $(1985,2000)$ describe this as a person's sense of efficacy or ability to effectively complete a particular task. Usually, achievement is gauged in the educational or occupational realms, but it can also concern the ways in which we relate to another. For instance, an individual can feel competent (or not) in their social interactions. Although competence and achievement are significant throughout the lifespan, it is important to explore in adolescence because it is at this stage that young people begin to prepare for future participation in occupational roles and the greater society (Masten et al., 1995). Additionally, it is at this stage that young people begin to cognitively understand that the successes they experience now may have an impact on their future success. For example, adolescents become more and more aware that academic achievement in school is related to their future college and carrer options, and ultimately their success. Development of competency tends to be cumulative; those who feel competent or able to achieve early on, tend to continue feeling able to achieve (Deci, 1975). Thus supporting an adolescent's sense of competency is important for their continued sense of competency throughout his or her lifetime.

Relatedness. Relatedness concerns an individual's interpersonal relationships and social competency. It is an important factor as research has shown that adolescents who establish healthy intimate relationships have greater life satisfaction and more positive psychological outcomes (Hightower, 1990). Intimate relationships, particularly with peers, become a key area of focus in a developing adolescent. In early adolescence pre-teens seek same-sex relationships 
and as they grow more mature, they seek opposite-sex relationships (Connolly, Furman, \& Knoarski, 2000; Doyle, Brendgen, Markiewicz, \& Kamkar, 2003; Sullivan, 1953). The more individuals feel they matter and have a sense of connection to other people in their lives; the more their psychological need for relatedness is fulfilled. Thus relatedness is the extent to which an individual feels they have warm, prosocial relationships with other people. A student who is alienated from her peer group and then goes home to neglectful parents may feel a tremendous lack of relatedness in her life. Early attachment style with a primary caregiver often predicts attachment style in adolescence (Ainsworth, 1979; Bowlby, 1969). Researchers have further shown that those who have secure adolescent attachments to peers and adults are generally more socially competent, more successful in school, and more adjusted than their insecurely attached peers (Allen \& Land, 1999).

Identity. Identity is a key task in psychosocial development. Identity is the extent to which an individual knows who he or she is in the world, it is a balance between his "internally defined selves and those selves that are defined, confirmed or denied by others" (Nakkula \& Toshalis, 2006, p.16). Much of the psychological research on identity originates with Erikson's (1963) delineation of eight psychosocial stages related to the major challenges a person encounters at particular points in the life span. Erikson (1963) asserted that identity formation was the main challenge of adolescence. Exploration is the key to identity development (Erikson, 1968; Grotevant, 1987), thus an individual's interactions with their social world, and the experiences one encounters, contribute to their developing sense of self (Erikson, 1968). Forming an identity becomes an interaction between individualized and environmental factors (Côté \& Schwartz, 2002). Through exploration, an individual makes decisions about the activities, people and choices that "fit" his or her sense of self. Research shows that individuals 
who encounter "crisis" or challenge through greater exposure to different experiences and contexts, will more likely attain identity achievement than those who do not (Bosma, 2001; Erikson, 1959; Kroger, Martinussen, \& Marcia, 2010). Marcia (1966) built on Erikson's theory by delineating four statuses of ego identity formation according to the extent to which an individual's exploration is integrated into a committed and unique sense of self. Marcia's statuses provide a framework for categorizing identity as: (a) achievement (high exploration; high commitment), (b) moratorium (high exploration, low commitment), (c) foreclosure (low exploration; high commitment), and (d) diffusion (low exploration; low commitment). Thus, the more commitment one feels to his or her explorations, the more one is identified as "achieved" (Marcia, 1966).

Context impacts identity development as it can limit or support the exploration process for an individual. Elements of context such as low SES or poor educational opportunity, have been shown to, in some cases, restrict a person's ability to grow a healthy, fully realized identity (Yoder, 2000). The recognition that the context of identity exploration is crucial has inspired many researchers to investigate the process of identity formation within particular contexts (Bosma, 2001). One's exploration cannot take place free of context (Erikson, 1968).

At the adolescent stage, identity development becomes a particularly salient task because individuals' brains develop to allow them to consider different, hypothetical ways of being (Dahl, 2001). Additionally, social influences and expectations change and allow them a "new array of choices and decisions" (Steinberg, 2008, p. 269). Healthy identity development has been linked to positive self-concept, self-esteem, and psychological well-being, (Schwartz, et al., 2011). Healthy identity achievement has also been linked to a person's sense of agency (Côté, 2000). Agency is an individual's sense of responsibility for self, control over their decisions, and ability to overcome 
challenges (Côté, 2000; Schwartz, Côté \& Arnett, 2005). Thus, agency, as a byproduct of healthy identity achievement, seems essential to one's positive and competent participation in society. Conversely, an underdeveloped identity results in individuals not prepared for the future (FerrerWreder, Palchuk, Poyrazli, Small \& Domitrovich, 2008). Some individuals may explore in ways that lead to risk factors such as substance abuse or poor academic outcomes (Luyckx, et al., 2006). As young people navigate the process of developing their identities, some struggle more than others (Waterman, 1999). Adolescents' sense of identity has implications for how they interact with people and environments, such as school, work, and community. It also impacts the behavior choices they make.

After consideration of the literature related to each of the key constructs in this study, a review of the relevant studies that empirically linked the different constructs were reviewed.

\section{Review of Relevant Research Studies}

Consistent with the conceptual model (see Figure A2), empirical research that links the key study variables is explored below. The school climate is first investigated in regards to research that also looked at Self-Determination Theory, or basic psychological needs satisfaction, which includes the developmental constructs of autonomy, competency, and relatedness. Next, studies designed to reveal associations between school climate, adolescent development, and identity development are highlighted. Finally, studies that linked school climate, adolescent development, and identity development to adjustment outcomes (academic achievement, substance use, and sexual risk factors in the present study) were summarized.

School climate and basic psychological needs satisfaction. The school climate consists of the physical, social, and psychological factors within a particular school setting that highlight what is valued. Self Determination theory is built on the notion that elements of the social 
environment are critical to the support of the basic psychological needs (autonomy, competency, and relatedness) satisfaction that lead to an individual's well-being and healthy development (Amorose, 2007; Deci \& Ryan, 2000). Although there is an emerging theoretical literature on how school climates can support adolescent psychosocial development, a relatively smaller number of empirical studies examine the relationship between school climate and and each of the individual's basic psychological needs satisfaction.

A growing body of research out of the Oklahoma Center for Education Policy investigates the way in which school climate supports self-determined motivation. Reseachers posit that school climates that foster trust support the development of autonomy, competence, and relatedness (Adams \& Forsyth, 2009). One of their studies shows that collective trust allows for students to expect a pattern of responsibilities from students and staff alike. Conversely, autonomy suppression occurs when environments lack trust (Adams \& Forsyth, 2009). Additionally, studies have found that students experienced greater autonomy, competence and relatedness (sometimes measured in the literature as just the outcome of internal motivation based on SDT) in environments that provided greater student-teacher, administrator relationships (Assor, Kaplan, \& Roth, 2002; Reeve, Ryan, Deci, \& Jang, 2008; Ryan, Stiller, \& Lynch, 1994), that made learning engaging and connected to adolescents through inquiry based learning and the allowance for independent thought (Jang, Reeve, \& Deci, 2010; Reeve \& Jang, 2006), and those that set high expectations with the appropriate scaffolds for student success (Niemiec \& Ryan, 2009; Reeve \& Jang, 2006).

One element of the educational context that has received more attention in extant literature is that of autonomy-supportive environments (Quested \& Duda, 2010). Autonomy support is created when a teacher involves the students in decision making, listens to, and 
respects the students' thoughts and opinions and provides opportunity for exploration through reduced pressure (Black \& Deci, 2000). One study measured 289 college students' autonomous self-regulation and autonomous motivation, as well as academic performance in a chemistry course (Black \& Deci, 2000). The authors found that all three variables were predicted by the perception of the course instructors' autonomy support. Similarly, a study of 264 individuals ages 8-20 were surveyed on their perception of autonomy support in the classroom. Multiple regression analyses indicated that autonomy supportive environments were associated with the individual's degree of autonomy, as measured by teacher report (Patrick, Skinner, \& Connell, 1993). Additional research done at the college level across different physical activities (including sports, dance, and physical education classes) found that autonomy supportive environments were predictive of satisfaction for the needs autonomy and relatedness (Adie, Duda \& Ntoumanis, 2008; Carr \& Wyon, 2003; Quested \& Duda, 2009; Reinboth \& Duda, 2006; Standage, Duda, \& Ntoumanis, 2003).

Although it was somewhat difficult to find studies examining the three basic psychological needs and early adolescents, an important study was done in the high school setting. This study endeavored to model how school and parenting environments impacted adolescent's sense of autonomy and competence (Vallerand, Fortier, \& Guay, 1997). This study used structural equation modeling to examine the associations across variables in a sample of 4, 537 students. Findings in this study revealed significant links between school administration, teachers, parents and their autonomy support for students within the school climate. School climates that exhibited higher autonomy support were associated with students' perceptions of greater competence and autonomy in the school setting (Vallerand, Fortier, \& Guay. 1997). 
Drawbacks to this study are the lack of inclusion of the three elements to self-determination theory, as well as having the outcome variable indicated by just two items.

Despite the relative lack of empirical research on the ways in which a school environment can support the satisfaction of basic psychological needs, there exists a plethora of research linking the support of autonomy, competency, and relatedness to positive adjustment outcomes, such as academic achievement (Tian, Chen, \& Huebner, 2014). Therefore, there could be tremendous value to understanding how a school can support such needs satisfaction. In addition to investigating the school environment and to what extent it supports the basic psychological needs: autonomy, competency, and relatedness, empirical research on identity formation in the school context was explored.

School climate and identity development. Based on the work of Erikson (1968), Lannegrand-Williems and Bosma (2006), and Waterman (1999), Sinai, Kaplan, and Flint stated that,

the school has long been considered an important context for the development of identity... [and] a social environment in which adolescents are exposed to new role models, experience new activities, encounter novel ideas, and engage in social interactions with adults and peers - all with potential contribution to their identity exploration. To a large extent, the type of people and activities in the school context frames and shapes the experiences that serve as material for adolescents' identity exploration and formation. (2012, p. 196)

In other words, when it comes to identity formation, schools matter. Several recent studies have further highlighted this position. For instance, it has been clearly demonstrated that students explore their identities within the school context (Flum \& Kaplan, 2012), that schools can 
intentionally enhance their learning environment to elicit increased identity exploration among its students (Sinai, et.al., 2012), and that schools which provide learning contexts with numerous identity promoting features help their students achieve desired psychosocial and academic outcomes (Rich \& Schachter, 2012). Flum and Kaplan (2006, 2003) outlined a conceptual framework for how the school climate could support identity formation; they suggested that schools needed to create exploration triggers, a sense of safety and exploratory scaffolds for students. Sinai and colleagues (2012) built on this research empirically, by qualitatively studying how this framework could impact the identity development of $669^{\text {th }}$ graders in Israel. What they found was that by creating triggers in a safe and scaffolded environment, students explored their identities.

Additionally, studies suggest that schools can intentionally improve student opportunities for identity exploration by increasing exposure to role models, providing students with meaningful academic experiences, and providing a range of opportunities for students to explore possible selves (Rich \& Schachter, 2012; Simona, 2009). Simona (2009) studied the role of context in identity development in 105 adolescents (ages 14-18). Participants were taken purposively from two sub-samples, one "at-risk" school and one more mainstream school. Next, the Possible Selves Questionnaire and the Self Perception profile were administered. Data were analyzed and showed different patterns of associations between the two groups, indicating that school contexts for "at-risk" students provided less opportunities for meaningful identity exploration (instead students focused on more superficial identity such as physical appearance) and did not focus as much on future possible selves as the "mainstream" school context.

A key study done by Rich and Schacter (2012) highlighted the various elements of the school social context that contributed to identity development with 2,787 high school students in 
Israel. Results showed that schools perceived as more identity promoting positively contributed to both students" "confidence in identity development" (sample item: "I feel that I am developing in a way that will enable me to be the person that I really want to be") and student exploration (sample item: I frequently devote thought to the question, "what do I want to do with my life"' (Rich \& Schacter, 2012, p.223). The independent variables that were considered identity promoting in this study included teacher caring, teacher as a role model, school cultivates whole student, affirming student exploration and agency, meaningful studies (studies that students saw the value of and felt connected to), and positive social climate. This study used structural equation modeling which indicated trends of affirming student exploration and agency and teacher as a role model as contributing the most to the prediction of high identity development and student exploration. (Rich \& Schachter, 2012)

Similarly, recent empirical work suggests that school climates rich in opportunities for identity exploration and development directly benefit students in many ways. For example, students who attend schools with higher rates of opportunities to explore their identity (examples included: guided self-reflection, relationship building with multiple role models, relevant literature that connects to the students, and access to varied electives and activities) also report higher levels of psychological health and wellbeing. These studies also showed that these types of schools are more likely to be characterized by students as motivating and engaging (Brophy, 2008; Faircloth, 2012; Sinai, et al., 2012). Importantly, students who attend schools that provide these opportunities to explore their identities enjoy improved academic outcomes as well as the benefits of healthy psychosocial growth (Skerett, 2012). This particular study finding came from a case study design that followed a student's progress through negative reading identity. Positive teacher experiences that encouraged the student to challenge existing identity construction, led to 
the student's internalization of a more positive identity which resulted in more positive academic outcomes. Climates in which teachers hold high expectations and withhold student prejudice, especially for adolescents who have been labeled low-level or poor-performing, contribute to a change from negative to positive self-identification for students (Skerett, 2012). Thus existing research indicates that through teacher interaction, role modeling, relevant curriculum, and guiding students through a variety of experiences, school climate can impact identity development in positive ways.

Although current theory and evidence suggest a strong relationship between school context and identity formation, several authors suggest the need for more empirical research in this promising area (Flum \& Kaplan, 2009; Schachter \& Rich, 2011; Sinai, Kaplan, \& Flint, 2012). In particular, Flum and Kaplan (2012) assert that in spite of many "indications of the relevancy of school experiences to the process of identity formation" (p.241), much more research needs to done in order to fully understand the relationship between the school context and identity development.

Adolescent development and identity development. Identity development is the key task of adolescent development (Erikson, 1968). Thus, developing one's identity is a piece of overall development through adolescence. Because identity development is dependent on exploration, the more competent, autonomous, and supported by others (relatedness) an individual feels the more likely they are to discover their true identity (Côté, 2000). This notion is supported by the research by Luyckx, et al. (2009) which investigated the associations between identity development and satisfaction of basic psychological needs (autonomy, competency, and relatedness). Their study combined structural equation modeling and cluster analyses in order to elucidate the potential relations between the two constructs within a high school and college age 
population. Results indicated meaningful paths between basic psychological needs and identity dimensions, although the bidirectional model fit the data best. When identity status clusters were investigated a sense of satisfied autonomy, competence, and relatedness was found to be significantly most related to the achieved identity status. This study supports the notion that dimensions of adolescent development are significantly associated with identity formation. Luyckx, et al. (p. 278, 2009) further point out that both Self-Determination Theory and Psychosocial Identity theorists agree on the essential ideas that humans are "proactive organisms" in their environments and are constantly endeavoring to build a cohesive sense of self by linking one's inner self to one's external world (for examples of this see: Ryan \& Deci, 2003; Luyckx, et al., 2009).

Building on this research and of particular importance to the current study's early adolescent sample, a longitudinal study was conducted to investigate how identity interacted with individuals' developmental trajectories overtime. Researchers used Latent Curve Growth Analysis to investigate identity development as it related to overall development between the ages of 12 and 30. Using Marcia's (1966) identity statuses, results showed that middle to late adolescents had higher frequencies in achieved identity rather than diffused identity. These results were reverse for early adolescents, with younger individuals less frequently being in the achieved identity status, this supports the notion that as individuals develop, their identity status follows a similar trajectory. Findings in this particular study further supported the notion that greater identity development was related to greater psychosocial development and associated outcomes overall. Specifically, for middle to late adolescents, the more time spent in moratorium or diffusion predicted greater levels of depression and delinquency (Meeus, van de Schoot, Keijsers, \& Branje, 2011). As discussed in the identity section, positive identity development is 
frequently found to be significantly associated with positive psychosocial adjustment (Arnett, 2000; Berman, Weems, \& Stickle, 2006; Steinberg, 2008). Because there is a vast literature linking identity development and adolescent development, only the most recent and explicitly related articles were included in this section.

\section{Adjustment Outcome Variables}

Risk behavior occurs based on a preponderance of individual and contextual factors, including the environments an individual interacts with and the individual's personal development. For instance, Battistich and Horn (1997) found that schools with a greater sense of community were much less likely to have students participating in risk behaviors associated with substance abuse and truancy. As noted in the adolescent development section, positive development is also associated with less risk behavior and more psychological well-being, often referred to as adjustment. Hence, studying the school climate, in conjunction with adolescent development, and how the interplay between individual and context impact adjustment outcomes seems a pertinent area of research.

Academic achievement. Academic success has been widely studied in American society. For decades, a focus on achievement as a mechanism for government funding of education has kept it a salient issue for policy makers, educational researchers, and practitioners. Importantly, academic attainment and achievement are linked to many essential outcomes for an individual's positive adjustment throughout life. In fact, academic success as an indicator for positive adjustment and well-being is generally accepted as fact (Bausch, 2010). Academic achievement has shown associations with many positive adjustment outcomes including increased physical health (Carlson et al., 2008; CDC, 2010; Srabstein \& Piazza, 2008; Spriggs \& Halpern, 2008), mental health (Asarnow et al., 2005, Hanson, Austin \& Lee-Bayha, 2004), social emotional 
competence (Masten et al., 2005; Roeser, Eccles, \& Sameroff, 2000), economic well-being (Bausch, 2010; National Research Council, 1999) and decreased risk factors such as high school drop-out (Eggert, Thompson, Herting Nicholas, \& Dicker, 1994) and early sexual activity or pregnancy (CDC, 2014). Thus, it is important to understand factors related to academic achievement because it can be an indicator for many positive outcomes.

Numerous studies have linked adolescent academic success to a positive school climate. Higher grade point averages have been associated with school environments with higher levels of school connectedness (Anderman, 2003; Niehaus, Rudasill, \& Rakes, 2012), more school involvement (Bryan et al., 2011), and positive teacher-student relationships (Wang, Eccles \& Kenny, 2013). Additionally, students who report higher levels of teacher support also report higher levels of academic effort, educational enjoyment, and academic self-efficacy (Sakiz, Pape, \& Hoy, 2012); while students who describe their school environment as positive, report both higher GPAs and higher levels of wellbeing (Ntalianis, 2010; Pietarinen, Soini, \& Pyhalto, 2014). In a study conducted with 170 adolescent students using three case study schools, structural equation modeling revealed that emotionally engaged teacher-student relationships, perceived school well-being, pedagogical skills, and cognitive engagement impacted school achievement as measured through grade point average (Pietarinen, et. al., 2014). School climates that have supportive faculty, organized systems, and a focus on academic mastery are also less likely to have students who drop out of school (Lee \& Burkham, 2000). School characteristics, and their impact on academic achievement, were indicated in a study using a sample of 3,840 high school students. Hierarchical linear modeling was used to analyze data and showed three important factors in schools that negatively predicted high school dropout. These factors included, school size (schools with less than 1500 students), academic focus in coursework, and 
most importantly, positive teacher-student relationships. Interestingly, the impact of teacherstudent relationships was dependent on organizational and structural characteristics of high schools (such as public versus private and low enrollment numbers) indicating the interplay between school contextual factors and individual student outcomes.

Substance Use and Abuse. Although substance use and abuse affects adults, it is a particularly salient issue in the lives of adolescents, regardless of socioeconomic status or racial background (Williams, 2011). In fact, substance use is still the number one cause of youth morbidity (Substance Abuse and Mental Health Services Administration, SAMHSA, 2010). Disturbingly, recent neurobiological research has shown that adolescent brains are much more susceptible to addiction as compared to their adult counterparts (Hiller-Sturmhofel, \& Swartzwelder, 2004). Furthermore, Hingson, Heeren, and Winter (2006) showed that individuals who begin drinking before the age of 14 were five times more likely to suffer from a substance abuse or dependence disorder at some point in their adult life. Repeated alcohol use can also negatively and permanently impact cognitive development including learning and memory (Tapert \& Brown, 1999). Substance abuse often occurs in conjunction with other internalizing (depression) or externalizing (aggression) risk behaviors. Thus, substance use and abuse in adolescence can inhibit academic achievement and positive adjustment.

Many links have been established between adolescent substance use and abuse and characteristics related to the school climate. For instance, young people who report higher levels of dissatisfaction with school (Takakura, Wake, \& Kobayashi, 2007), negative experiences at school (Ford, 2009; Trenz et al., 2012), non-participation in school activities (Ford, 2009), or disengagement with academics and school in general (Ford, 2009; Henry, Knight, \& Thornberry, 2012), are more likely to drink alcohol, drive drunk, or use other illicit substances. Data from 
the Rochester Youth Development Study was used to analyze 911 adolescents in regards to their school disengagement and substance use (Ford, 2009). Probit regressions revealed strong associations between high levels of school disengagement and substance abuse.

Conversely, students who report higher levels of the positive dimensions of school climate, such as school connectedness (Chapman, Buckley, Reveruzzi, \& Sheehan, 2014; McNeely, Nonnaker, \& Blum, 2002), greater involvement in school activities (Gianotta \& Ozdemir, 2013) and positive experiences with school - including being in a school climate characterized by academic success, (Clark et al., 2014) are less likely to use alcohol, marijuana, and other drugs. Perhaps the most encouraging finding demonstrates that school climate-focused interventions, particularly those related to school connectedness, can contribute to reducing rates of current substance use among the student population (Drolet, Arcand, Ducharme, \& LeBlanc, 2013). This particular qualitative study focused on an evidence-based intervention program shown to be successful in the delay of substance use for adolescents. Twenty-six adolescents and 8 teachers were included in the analysis. Students and teachers participated in semistructured interviews and qualitative analysis revealed patterns that supported that the school climate-based intervention program was potentially successful due to the fact that it taught teachers how to promote self-confidence, capacity for self-assertion, positive interpersonal relationships, and group solidarity to students. In other words, the success of this program was rooted in the school climate level changes for adolescents participating in the study. Furthermore, Henry and Slater (2007) asserted, "Our findings, along with the findings of related studies, provide support for the hypothesis that improvement of school climate may result in less substance use among students" (p. 67). Thus providing support for the promising aspects of research related to substance use, school climate, and adolescent development. 
Sexual Risk Behavior. Sexual risk behaviors include early sexual debut, participating in unprotected sex or sex with many partners and can lead to early teen parenting or sexually transmitted infection and disease (CDC, 2002). Although sexual risk exists in adulthood as well, “adolescents may lack the experience or mature judgment to assess risks and make good decisions under pressure," (McMahan, 2009, p. 421). Alarmingly, over one third of sexually active girls become pregnant at some point in their teenage years (CDC, 2014b). Girls who become pregnant are likely to drop out of school and have difficulty finding work (Leadbetter \& Way, 2001). The National Youth Risk Behavior Survey (2009) shows a negative association between sexual risk behaviors and school grades, providing some indication that academic success is linked with sexual risk behavior.

Further, several links have been established connecting adolescent sexual risk behavior and characteristics related to the school climate. For example, young people reporting higher rates of the positive dimensions of school climate such as school connectedness (Saewyc, Taylor, Homma, \& Olgivie, 2008; McNeely, Nonnaker, \& Blum, 2002) and liking school (Parkes et al., 2014) participate in lower rates of protected sexual intercourse and later sexual debut. Parkes and colleagues (2014) studied the association between school problems and early sexual behavior. This study used a subsample $\left(n=4,739\right.$, mean age $=15 \frac{1}{2}$ years old $)$ from the Avon Longitudinal study of Parents and Children. Data from several time points were collected including school like/dislike and sexual activity. School dislike predicted early sexual behavior (preceding age 13), particularly when school dislike was consistent across observations, even when gender, age, SES, family problems, and father absence were controlled in the analysis. Likewise, schools characterized as having institutional features that promote sense of school safety, positive relationships between students and staff, and higher levels of student 
academic engagement and participation in school activities report lower levels of risky sexual behavior (Jamal et al., 2013). However, young people reporting higher rates of the negative dimensions of school climate such as disliking school (Parkes et al., 2014), need to "escape" from school by participating in risk behavior (Jamal et al., 2013), or a attending a school with a hopeless "nothing to lose" culture (Harris, Duncan, \& Boisjoly, 2002) are associated with early sexual debut and higher rates of unprotected and protected sexual activity.

Furthermore, the non-academic norms of the school climate can influence developmental, health, and academic outcomes. For instance, school-level norms regarding the social acceptability of teen pregnancy are strongly associated with higher rates of teen pregnancy, while schools with clear norms against teen pregnancy and a greater consensus around that norm demonstrate lower rates of teen pregnancy (Mollborn, Domingue, \& Boardman, 2014). This particular study compared school norms regarding teen pregnancy across 75 US high schools using the school-based National Longitudinal Study of Adolescent Health. School environments with both stronger than average norms against teen pregnancy and greater consensus around the norms were predictive of lower pregnancy rates (Mollborn, et. al., 2014). This is important, because positive school climates associated with academic engagement are more likely to have clear norms against teen pregnancy.

Relatedly, school environments that perpetuate less positive norms around sexual behavior (such as ignoring and/or accepting sexual harassment) have a negative impact on students. A recent study demonstrated that hostile school environments (characterized by higher rates of sexual harassment) contribute to decreased overall emotional health and increased levels of risk factors associated with more participation in a variety of health risk behaviors (Gadin \& Hammarstrom, 2005). This finding was particularly alarming because across samples, young 
women experienced sexual harassment at a much greater rate than young men, even in schools that were not characterized as hostile, thus providing some support for the idea that school climates can negatively impact risk behavior, and in this case, can differentially impact females and males. Adding to the above research, Oliveira-Campos, Giatti, Malta, and Barreto (2013) suggest that because the school environment influences adolescent decisions to participate in sexual risk behavior, it is important to develop a holistic and comprehensive understanding of the school climate and the pathways by which it asserts its influence on these outcomes (OliveiraCampos et al., 2013).

\section{Summary}

This chapter highlights the relevant literature and shows the importance of the school climate, basic psychological development needs satisfaction, and adjustment outcomes as indicators of academic and behavioral success. The literature is presented in order to build a strong case for the importance of studying the conceptual model that shows the interaction between school climate and individual development, and the behaviors associated with this proposed relationship. Many interconnected concepts are seen across the constructs in this study. Thus rather than looking at them each as independent pathways, it makes sense to look at them in concert with one another in a simultaneous fashion. This study endeavors to explore the associations between adolescent development, school climate, and risk behaviors predictive of positive adjustment. The literature review led to the following research questions:

\section{Quantitative Research Questions with Associated Hypotheses}

1) What is the pattern of association between school climate and adolescent development?

Hypothesis 1: Positive school climate is positively related to higher basic psychological needs satisfaction. 
2) How are school climate and adolescent development associated with Identity Development?

Hypothesis 2: Positive school climate and adolescent development are positively related to identity formation.

3) What are the relations between the latent constructs in the hypothesized model and how do they affect adjustment outcomes?

Hypothesis 3. Positive school climate and development are positively related to academic achievement and negatively related to substance use and sexual risk factors.

4) Are the effects of school climate and adolescent development on adjustment outcomes mediated by identity development?

Hypothesis 4: The above associations will be partially mediated by the extent to which students have formed a healthy identity. 


\section{Chapter 3: Methodology}

\section{Overview of Research Design}

A quantitative cross-sectional research design was employed in this dissertation. This research was conducted as part of a larger longitudinal study occurring through the West Virginia School of Public Health's Icelandic Community Engagement Model (ICE) Collaborative Project (PI: Alfgeir Kristjansson). Only data from Year 1 was utilized for analyses in the present study. Data were analyzed using Correlation, Hierarchical Multiple Regression (SPSS V 22) and Structural Equation Modeling (Mplus). For a visual depiction of the variables and constructs see Figure A2, for the proposed conceptual model, see Figure A3.

\section{Key Study Variables}

Key study variables included school climate, adolescent development (as measured by basic psychological needs satisfaction), identity development, and adjustment outcomes (academic achievement, substance use, and sexual risk). Control variables in the study included potentially confounding demographic variables of age and race. Additionally, gender was controlled for because several research studies on education have found gender differences in school related outcomes (Delamont, 2012; Legewie \& DiPrete, 2012). Household structure (whether young people were living in two parent homes or not) and maternal education (as an indicator for SES) were also controlled in order to avoid the potentially confounding influence of such variables. SES has often been linked to educational attainment (South, Baumer, \& Lutz, 2003; Teachman, 1987).

\section{Participants}

Sample. Participants $(n=1,130)$ were enrolled in three West Virginia middle schools (grades $6-8^{\text {th }}$ ). The process for gaining access to schools included meeting with key officials in 
the State Department of Education, meeting with Regional Education Service Agency (RESA) directors and principals, and, finally, meeting with school and district personnel to discuss plans and partnerships. The current study sample comprised of early adolescents between the ages of $11-15(M=12.54), 49 \%$ of the sample identified as male gender and $50 \%$ identified as female (1\% did not report gender). The sample primarily identified as White (80.6\%), followed by Other (9.1\%), American Indian/Native American (6.1\%), Black (2.1\%), with Asian and Pacific Islander both less than $1 \%$. Sixty-one percent of the sample participants lived in two parent homes and 39\% lived in some other household configuration. All three schools were located in a single Appalachian county. Just over $18 \%$ of the county population aged 25 and older have a Bachelor's degree or higher and the median income in this county is $\$ 42,287$. Per capita money income in past 12 months (for the year 2013) was \$24, 042 (U.S. Census Bureau, 2015). Overall, according to the U.S. Census Bureau (2015), 51.3\% of the West Virginia population is rural and $97.3 \%$ of the land is considered in rural areas.

During the data cleaning process, 1 survey was eliminated due to double entry, 20 were eliminated due to answering $15 \%$ of the questions or less, and 2 were deleted due to systematic answering. After these were removed our response rate was calculated to be $82.4 \%$ of the middle school sample included in this study.

Consent Process. The Ice Collaborative research team met with the West Virginia State Department of Education and received approval for this particular research study. From that meeting, the State Department of Education organized a meeting with all RESA directors. Next, RESA directors presented the idea of this study to their public school districts. All public middle and high schools in the state of West Virginia who were interested met with the research team to discuss a mutually beneficial and longitudinal partnership within this study. At this time, five 
schools have selected to be a part of this study for five years, three of them were middle schools. As approval was given by principals and superintendents, this information was shared with the Institutional Review Board (IRB) at West Virginia University (WVU), along with all study goals and parameters. Once a school consented to taking part in the study, they were asked to sign the appropriate IRB waivers, consent forms, and an amendment to the protocol was submitted to IRB.

West Virginia University’s IRB approved this study (Figure B2). IRB granted permission for passive consent which means that the right to remove their child from participation in the study was given to all parents of enrolled students at each of the schools. Consent letters were sent home to all students' parents (Figure B3). If parents chose not to provide consent they could return their paper form to the school or call the administrator or the PI to directly provide nonconsent. Passive parental consent was accompanied by information about the study. According to WVU IRB, informed passive consent was acceptable in this case because there was no more than minimal risk associated with this study. Additionally, WVU IRB has stated that the benefits well outweigh the harm in this study, thus passive consent was acceptable. After three weeks were allowed for the collection of non-consent, the study commenced. School administrators responsible for making sure that no student on the non-consent list participated in the study.

\section{Procedures}

Quantitative instruments were given in the second and third months of school (September and October of 2014). Every effort was made to choose a day when attendance was most likely (when students were not away on field trips or sporting events). In most cases, surveys were administered during third period. Teachers were trained in advance with instructions on how to administer the survey; they were also provided with instructions for the day of the survey. Paper 
and pencil surveys were distributed in third period classrooms and electronic surveys were taken in computer labs. Teachers took attendance for those present. Those students who were absent were added to a "make-up" list and most were able to participate in the survey on one of three make-up days. Every effort was made to obtain at least an $80 \%$ response rate. Teachers explained to students that their answers would not be shared and no teacher, administration, or family member would have access to their responses. Teachers were also instructed to explain that students were not obligated to participate. When students signed on to the computers (or opened their paper survey), an information page appeared that explained the purpose of the survey in general and repeated their consent rights. By clicking the continue button (or continuing with the survey) after reading the assent letter (Figure B1), students provided their assent. Students who took the survey electronically submitted their answers on a secure website hosted by RedCap. Those who took the paper and pencil survey placed their completed responses into a large folder and fastened it shut. Students used only their student identification number (WVEIS ID\#) to identify themselves in order to preserve confidentiality.

Data Collection. The quantitative survey data were collected at the individual level at each of the three schools. The sample consisted of all present, consented students in attendance on the days the research team gave the survey. Students used school computer labs to access the survey via RedCap. The research team then uploaded the data for analysis into SPSS. Paper and pencil versions of the survey were collected by school administrators and collected from the school by the research team. Next, a team of research assistants entered the paper data into SPSS. The quantitative instrument gathered data on the following variables; demographics, school climate, adolescent development (basic psychological needs satisfaction), identity development, and adjustment outcomes (academic achievement, substance use, and sexual risk). 


\section{Instrumentation}

This section will detail each data collection instrument. The present study, in addition to a demographics questionnaire, included multiple quantitative measures: The School Climate Measure, the Basic Psychological Needs Measure, the Dimensions of Identity Development Scale, and selected questions from The Youth Risk Behavior Surveillance Survey to assess substance abuse and sexual risk behaviors. Details on each quantitative instrument are below:

Demographics. Demographics were collected through self-report including gender, age, grade, race, family structure, academic achievement in Math and English, household structure, and maternal education.

School Climate Measure. The School Climate Measure is a self-report measure that asks students to respond to several questions about their experiences at school (Zullig, et al., 2010). This instrument was used to measure students' perception of school environment.

Questions range from those about relationships with teachers to perceived "mattering" in the school community (See Appendix C, Figure C1 for the full measure). Responses are answered on a Likert scale ( $1=$ strongly disagree to $5=$ strongly agree). Of the 42 total items, there are ten subscales:

1) Positive Student-Teacher Relationship (8 items; Cronbach's alpha: .92; sample item: “Teachers understand my problems").

2) Order and Discipline (6 items; Cronbach's alpha: .89; sample item: "The rules of the school are fair").

3) Positive Student Engagement (6 items; Cronbach's alpha: .88; sample item: "Nobody in my school is excluded from being successful").

4) School Physical Environment (4 items; Cronbach's alpha: .93; sample item: "The 
school is neat and clean").

5) Academic Support (4 items; Cronbach's alpha: .85; sample item: "I believe that teachers expect all students to learn").

6) Parental Involvement (3 items; Cronbach's alpha: .79; sample item: "My parents are involved in school activities").

7) School Connectedness (4 items; Cronbach's alpha: .86; sample item: “This school makes students enthusiastic about learning").

8) Perceived Exclusion/Privilege (3 items; Cronbach's alpha: .89; sample item: “At my school, the same person always gets to help the teacher").

9) School Social Environment (2 items; Cronbach's alpha: .87; sample item: "I am happy with the kinds of students who go to my school").

10) Academic Satisfaction (2 items; Cronbach's alpha: .78; sample item: "I am happy about the amount of homework I have").

This instrument has been used with high school and middle school students in the past with success, and has been used consistently throughout Arizona public schools as the primary measure of school climate (Zullig et al., 2013; Zullig, Ajamie, et al., in press; Zullig \& Patton, 2011). The latent construct of school climate was indicated by the mean for each of the 10 subscales.

Basic Psychological Needs Satisfaction Measure. The Basic Psychological Needs Satisfaction Measure is a measure based on Self Determination Theory that looks at the extent to which the needs for autonomy, competency, and relatedness are being met in a particular context (Deci \& Ryan, 2000). Students respond to the items on a 7-point Likert scale (1=not at all true, $7=$ very true). Of the 21 total items on the instrument (see Appendix C, Figure C2 for the full 
measure), there are three subscales:

1) The Autonomy subscale (7 items; Cronbach's alpha: .60; sample item: "I feel pressured in life").

2) The Competency subscale (6 items; Cronbach's alpha: .55; sample item: "I often do not feel very capable").

3) The Relatedness subscale (8 items, Cronbach's alpha: .72; sample item: "I really like the people I interact with").

This instrument was used to measure to what extent students' developmental needs for autonomy, competence and relatedness were satisfied. The Basic Psychological Needs Satisfaction measure has been used across contexts with adolescent populations (Chrikov \& Ryan, 2001; Van Ryzin, Gravely \& Roseth, 2009). Overall Cronbach's Alpha for the measure was .98. The latent construct of adolescent development was indicated by the mean for each of the 3 subscales.

Dimensions of Identity Development Scale. The Dimensions of Identity Development Scale was specifically designed to measure adolescents' sense of identity both the extent to which they are exploring and the extent to which they have committed to a particular identity (Luyckx, Goossens, Soenens, \& Beyers, 2006). This instrument was used to measure the students' positive identity development (see Appendix C, Figure C3 for the full measure). Responses were measured on a 5-point Likert scale ( $1=$ Strongly disagree, $5=$ Strongly agree) Of the 25 items, there are five subscales:

1) Commitment Making (5 items; Cronbach's alpha: .94; sample item: "I have plans for what I am going to do in the future"). 
2) Exploration in Breadth (5 items; Cronbach's alpha: .91; sample item: "I think about different things I might do in the future").

3) Identification with Commitment (5 items; Cronbach's alpha: .91; sample item: "My future plans give me self-confidence").

4) Exploration in Depth (5 items; Cronbach's alpha: .86; sample item: "I talk with other people about my plans for the future").

5) Ruminative Exploration (5 items; Cronbach's alpha: .84; sample item: "I keep looking for the direction I want to take in my life").

Scores from the five subscales are combined to yield six identity status clusters. Those who are high in both exploration subscales, moderate to high in commitment, and low in ruminative exploration have shown associations with positive adjustment across several constructs (Luyckx, et al., 2007). This measure was created with adolescents and emerging adults in mind (Luyckx, et al., 2006). In the current study the first four subscales were used to indicate the latent variable of positive identity development, these four subscales had an overall Cronbach's alpha of .95 .

\section{Rates and Incidence of Health Behaviors associated with Adjustment Outcomes.}

Three areas of adjustment were measured: academic achievement (using self-reported grades for English and Math, and self-reported effort compared to other students), substance use \& abuse, and sexual risk behavior (for the survey in its entirety, see Appendix D). In order to measure the latter two adjustment outcomes, substance use and sexual risk, items were selected from the widely utilized and accepted National Youth Risk Behavior Surveillance survey (YRBS). The YRBS measures six types of risk behavior including unintentional injury and violence, sexual behaviors, alcohol and drug use, tobacco use, unhealthy diet, and inadequate physical activity. It 
is a school-based survey collected at the middle and high school level. The CDC has been collecting and publishing the data from this survey since 1991 (CDC, 2014a). This questionnaire will be used to measure the rate and severity of risk behaviors including alcohol consumption, drug use and risky sex behavior such as unprotected sex and teen pregnancy rates. There are 12 items that measure substance abuse. These items cover cigarettes, tobacco products, alcohol, and drugs. Rates of behaviors are captured with the stem; "During the past 30 days/12 months, how often have you..." and participants respond by choosing one of the following options: (a) Never, (b) 1-2 times, (c) 3-5 times, (d) 6-9 times, (e) 10-19 times, (f) 20-39 times, or (g) 40 times or more. For sexual risk behavior, five items ask about sexual activity including age at first intercourse, number of partners, sexual intercourse under the influence, and two items about contraceptive use.

\section{Data analysis}

Quantitative data was analyzed using SPSS and Mplus. Structural Equation Modeling (SEM) was the primary mode of analysis due to the ability for SEM to represent and test a network of relationships between variables, both measured and latent constructs (Kline, 2010; Rigdon, 1998). Structural Equation Modeling requires specification of a model based on theory and research (Hoyle, 1995), explicitly specifies measurement error, and allows researchers to test models with both observed and latent variables in a single model. Both Path Analysis (regression) and confirmatory factor analysis (CFA), which are both part of SEM, (Kline, 2010) were used. SEM makes it possible to determine parameter estimates by solving multiple equations simultaneously (Kline, 2010). In order to evaluate model fit, multiple fit indices were examined, including Chi Square, Comparative Fit Index (CFI), Standardized Root Mean Squared Residual (SRMR) and the Root Mean Squared Error of Approximation (RMSEA). Hu and 
Bentler's (1999) cut-off criteria for fit indices were used to evaluate model fit. Using SEM also helps with potential issues of multicollinearity. In summation, the current research hypothesizes a complex relationship between school climate, developmental needs satisfaction, and adjustment outcomes. The Structural Equation Modeling technique met the analysis needs of the present research. 


\section{Chapter 4: Results}

\section{Preliminary Analyses}

\section{Bivariate Correlations between Study Variables (See Appendix D, Table D2).}

Bivariate associations were examined in a set of simple correlations. The ten school climate sub scales, three adolescent development subscales, and four identity development subscales were all weak to very strongly and positively correlated with both adolescent and identity development variables. It was hypothesized that higher levels of positive school climate, adolescent development, and identity development, would be associated with higher levels of academic achievement. It was also hypothesized that higher levels of positive school climate, adolescent development, and identity development, would be associated with lower levels of substance use and sexual risk behavior. Correlations across these variables provided initial support for these predictions as well. Finally, it was expected that related subscales associated with the proposed latent constructs would all be significantly and strongly associated. Correlational analyses provided support for these predictions, showing significant, strong to very strong associations between related subscales. All study variables were significantly related to one another. In sum, correlational analyses provided initial support for the hypotheses tested in this research study.

Next, correlations were run between study and control variables (gender, SES, age, household configuration, and race). Of the 63 correlations run between study variables and control variables, 14 were significant $(p<.05)$. All associations were weak (less than .20 , Cohen, 1992). After this preliminary correlational analysis, the research questions were investigated with further analysis. 


\section{Research Question \#1: What is the pattern of association between School Climate and}

\section{Adolescent Development?}

A hierarchical multiple regression model was run in order to examine how adolescent development was associated with school climate. Race, household configuration, gender, and age were controlled for in the model. Assumptions of linearity, independence of errors, homoscedasticity, unusual points and normality of residuals were met. School climate was significantly associated with adolescent development, $F(14,989)=34.15, p<.05$, adj. $R^{2}=.32$. Of the control variables, white race and two-parent households were significantly predictive of adolescent development. Of the ten school climate subscales, six added significantly to the prediction of adolescent development $(p<.05)$. Regression coefficients and standard errors can be found in Table D3. Higher perceived school social environment, followed by student-teacher relationships, perceived inclusion, academic support, student engagement, and parental involvement were significantly associated with higher levels of adolescent development. In sum, control variables accounted for $4 \%$ of the variance in adolescent development. When school climate variables were added in the present model accounted for $32 \%$ of the variance in adolescent development, with particular aspects having more weight than others.

\section{Research Question \#2: How are school climate and adolescent development associated with}

\section{identity development?}

A hierarchical multiple regression model was run in order to examine how school climate and adolescent development were associated with identity development. The assumptions of linearity, independence of errors, homoscedasticity, unusual points and normality of residuals were met. School climate and adolescent development were significantly associated with identity development, $F(17,949)=20.41, p<.05$, adj. $R^{2}=.26$. None of the control variables were 
significantly predictive of identity development in the present model. Three of the ten school climate subscales and two of the three adolescent development subscales added significantly to the prediction of identity development $(p<.05)$. Regression coefficients and standard errors can be found in Table D4. Higher perceived Relatedness satisfaction, followed by parental involvement (SC subscale 6), academic support (SC subscale 5), and Autonomy satisfaction were significantly associated with greater positive identity development. A significant negative association was present between school social environment and positive identity development. In sum, School Climate and adolescent development accounted for $26 \%$ of the variance in positive identity development, with particular aspects having more weight than others. This question was further analyzed as part of the structural models run for Research Question \#3.

\section{Research Question \#3: What are the relations between the latent constructs in the hypothesized model and how do they affect adjustment outcomes?}

Three structural equation models were conducted to simultaneously examine associations between school climate, adolescent development, identity development, and each of the three adjustment outcomes separately. All models were structured identically, with the exception of the dependent variable (adjustment outcomes). Models were evaluated using several fit indices. Hu \& Bentler's (1999) widely employed fit criteria were used to determine good fit. Although the Chi-square value for the overall model fit for each of these models was significant, which could suggest a lack of fit between the hypothesized model and the data, due to the sensitivity of the Chi-square fit statistic to large sample sizes, other fit indices were assessed (Kline, 2011). According to Tabachnick \& Fidell (2012), even though Chi-Square is often used as a fit index, chi-square would be expected to be significant even in the case of good model fit because of the large sample size used in this study. Hancock \& Mueller (2013) assert that in structural equation 
modeling three types of fit should be evaluated: 1) absolute fit; using SRMR $\leq .08,2$ )

parsimonious fit; using RMSEA $\leq .06$, and 3) Incremental fit; $\mathrm{CFI} \geq .95$. All models had adequate to excellent fit according to several model fit standards (Hancock \& Mueller, 2013; Hu \& Bentler, 1999; Kline, 2003). The first step in a structural model is using Confirmatory Factor Analysis (CFA) to assess whether or not the factor structure indicates the latent constructs as hypothesized. CFAs are presented below for each latent variable in detail.

School Climate. For the school climate latent factor, 10 indicators were included in the CFA. Modification indices suggested freeing the covariance between two different sets of error terms. Thus, school climate subscales 10 and 7, and school climate subscales 4 and 1 were allowed to correlate. Model fit statistics were assessed using SRMR and CFI which were suggested by authors Browne and Cudeck (1993) as adequate criteria for model fit when assessing only the measurement portion of the model. SRMR was .03 and CFI was .96. All indicators loaded significantly onto this factor (standardized loadings ranged from .40 to .86, estimated ranged from .47 to $1.00, p<.01)$.

Adolescent Development. For the adolescent development latent factor, 3 indicators were included in the CFA. Model fit statistics were assessed. The model was just identified thus producing a SRMR of .00 and a CFI of 1.00. All indicators loaded significantly onto this factor (standardized loadings ranged from .72 to .95 , estimated ranged from 1.00 to $1.32, p<.01$ ).

Identity Development. For the identity latent factor, 4 indicators were included in the CFA. Modification indices suggested freeing the covariance between Identification with Commitment and Commitment Making, so these indicators were allowed to correlate. Model fit statistics were assessed. SRMR was .01 and CFI was .98. All indicators loaded significantly onto 
this factor (standardized loadings ranged from .70 to .75, estimated ranged from 1.00 to 1.07 , $p<.01)$.

Confirmatory Factor Analyses (CFAs) for each latent construct suggested good fit and supported the validity of the measurement portion of the model (See Table D5). Associations between the latent constructs were consistent with the multiple regression findings from Research Question \#2. Identity development was approximately .39 higher per standard deviation unit of higher adolescent development and approximately .27 higher per standard deviation unit of positive school climate. Specific results for each adjustment outcome are included below.

Academic Achievement. A structural model was conducted to examine associations between school climate, adolescent development, identity development and the observed variable of academic achievement (Figure D6). Model fit was good, RMSEA= .06 (CI .05-.06), CFI= .94, and $\mathrm{SRMR}=.05$. Consistent with study hypotheses, positive school climate and adolescent development were associated with positive identity development, which was, in turn, associated with higher academic achievement. This suggests that school climate, adolescent development, and identity development work in concert to impact the adjustment outcome of academic achievement. Finally, a t-test was conducted to determine whether or not the coefficients for school climate and adolescent development were significantly different from one another. Results indicated that adolescent development was significantly higher than school climate in association with identity formation and academic achievement $(t(2,256)=3.27, p<.01)$.

Substance Use. A structural model was conducted to examine associations between school climate, adolescent development, identity development and the observed variable of substance use (Figure D7). Model fit was good, RMSEA = .06 (CI .05-.06), CFI= .95, and 
$\mathrm{SRMR}=.05$. Consistent with study hypotheses, positive school climate and adolescent development were associated with positive identity development, which was, in turn, associated with lower rates of substance use. This suggests that school climate, adolescent development, and identity development work in concert to impact substance use. Finally, a t-test was conducted to determine whether or not the coefficients for school climate and adolescent development were significantly different from one another. Results indicated that adolescent development was significantly higher than school climate in association with identity formation $(t(2,256)=2.91, p<.01)$.

Sexual Risk. A structural model was conducted to simultaneously examine associations between school climate, adolescent development, identity development and the observed variable of sexual risk (Figure D8). Model fit was good, RMSEA= .06 (CI .05-.06), CFI= .96, and $\mathrm{SRMR}=.04$. Consistent with study hypotheses, positive school climate and adolescent development were associated with positive identity development, which was, in turn, associated with lower rates of sexual risk. This suggests that school climate, adolescent development, and identity development work in concert to impact sexual risk. Finally, a t-test was conducted to determine whether or not the coefficients for school climate and adolescent development were significantly different from one another. Results indicated that adolescent development was significantly higher than school climate in association with identity formation and sexual risk $(t$ $(2,256)=3.09, \mathrm{p}<.01)$

\section{Research Question \#4: Are the effects of School Climate and Adolescent Development on adjustment outcomes mediated by Identity Development?}

Follow up Sobel tests for significant mediation effects were run in order to investigate the hypothesis about identity partially mediating the relations between school climate and adolescent 
development and the included adjustment outcomes; academic achievement, substance use, and sexual risk behavior (Baron \& Kenny, 1986; Sobel, 1986). The Aroian version of the test equation was used, as has been suggested, and widely accepted, by meditational effects researchers (MacKinnon, Warsi, \& Dwyer, 1995; Preacher \& Hayes, 2008). The Aroian test equation is as follows: $z-v a l u e=a * b / S Q R T(b 2 * s a 2+a 2 * s b 2+s a 2 * s b 2)$. Prior to running Sobel tests, the structural models for each outcome variable were evaluated to make sure they met the conditions for mediation. Baron and Kenny (1986) suggested that there be a significant association between the independent variables and the outcome variables, a significant association between the independent variable and the mediating variable, and a significant regression association between both the independent and the mediator variable on the outcome variables. Mediation criteria were met in each model. The Sobel tests whether or not including the mediator variable significantly reduces or eliminates the associations between the independent variable (i.e., school climate and adolescent development) and the dependent variable (i.e., academic achievement, substance use, and sexual risk factors). All structural models for each of the adjustment outcomes showed significant mediation effects. Specific results for each adjustment outcome are included below.

Academic Achievement. Identity as a mediator between both school climate and adolescent development and academic achievement was tested using Sobel tests. Identity acted as a significant mediator for both effects of school climate $(z=-4.85, S E=.01, \mathrm{p}<.01)$, and adolescent development $(z=-5.63, S E=.02, \mathrm{p}<.01)$. Thus, the model indicates that identity development accounts for some of the relationship between the independent variables; school climate and adolescent development, and the dependent variable of academic achievement. 
Substance Use. Identity as a mediator between both school climate and adolescent development and substance use was tested using Sobel tests. Identity acted as a significant mediator for both effects of school climate $(z=-3.86, S E=.02, \mathrm{p}<.01)$, and adolescent development $(z=-4.18, S E=.04, \mathrm{p}<.01)$. Thus, the model indicates that identity development accounts for some of the relationship between the independent variables; school climate and adolescent development, and the dependent variable of substance use.

Sexual Risk. Identity as a mediator between both school climate and adolescent development and sexual risk was tested using Sobel tests. Identity acted as a significant mediator for both effects of school climate $(z=-3.19, S E=.01, \mathrm{p}<.01)$, and adolescent development $(z=-$ $3.39, S E=.01, \mathrm{p}<.01)$. Thus, the model indicates that identity development accounts for some of the relationship between the independent variables; school climate and adolescent development, and the dependent variable of sexual risk. 


\section{Chapter 5: Discussion}

The primary intent of the current study was to model the combined influence of school climate, adolescent development, and identity development on adjustment outcomes. The goal was to more holistically capture the processes associated with indicators of adjustment; specifically academic achievement, substance use, and sexual risk behaviors. The models

presented in this study are based on Self Determination Theory and empirical work independently linking these constructs (Deci \& Ryan, 2000; Luyckx, et al., 2009; Roeser, 2005; Stewart; 2008). Educational research often focuses on elements of school climate and developmental research has looked extensively at adolescent development; the current study sought to wed educational and developmental research into one study model. Further, existing research often looks at just one element of school climate (for example school connectedness; McNeely, Nonnaker, \& Blum, 2002) and often uses adjustment outcomes (for example substance use; Engberg \& Morral, 2006; or externalizing behaviors; Harrell, Mercer, \& DeRosier, 2008) to indicate development. In contrast, this study examines adolescent development according to basic psychological needs satisfaction. Further, the current study looks at 10 empirically valid aspects of school climate and their direct associations with the developmental needs satisfaction of adolescents. Further, it focuses the investigation on early adolescents who are relatively understudied compared to late adolescents, children and infants (Wright et al., 2006). The current study focused on the following four hypotheses each of which were linked to the four guiding research questions:

1) Hypothesis 1: Positive school climate is positively related to higher basic psychological needs satisfaction. 
2) Hypothesis 2: Positive school climate and adolescent development are positively related to identity formation.

3) Hypothesis 3. Positive school climate and development are positively related to academic achievement and negatively related to substance use and sexual risk factors.

4) Hypothesis 4: The above associations will be partially mediated by the extent to which students have formed a healthy identity.

All four hypotheses were supported by the study findings and extended the understanding of the processes involved in adolescent adjustment outcomes. Findings related to each research question are addressed in this discussion including potential future directions. Second, the strengths and limitations of this study are discussed. Finally, implications for future research and practice in this area are highlighted.

\section{Research Question \#1: What is the pattern of association between school climate and adolescent development?}

From an ecological perspective, developmental researchers understand that context and development are linked (Bronfenbrenner \& Morris, 2006; McMahan, 2009; Steinberg, 2008). We also know that there are four main contextual domains that American adolescents grow up in (e.g. families, schools, peers, and culture). The purpose of this study was to further investigate the ways in which the elements of the school context are associated with the adolescent developmental process. This is particularly salient in the early adolescent population, as research shows that early adolescents are at a key moment in their development; physically, cognitively, and socio-emotionally (Steinberg, 2008). For early adolescents, rapid change in their brain development, as well as the growing demands and responsibilities from their environments, 
creates a window for great potential or great risk (Spear, 2000). Thus studying the specific ways in which elements of school climate directly relate to developmental needs satisfaction is important. As hypothesized, more positive school climate ratings were associated with more positive needs satisfaction within adolescent development. This finding is consistent with several studies that found significant relations between school climate and developmental outcomes (Bear, Yang, Pell, \& Gaskins, 2014; Klein, 1997; NSCC, 2013; Resnick et. al., 1997). The strength of this study is the use of a more comprehensive and psychometrically sound measure for school climate that allows for better understanding of the specific aspects of school climate that most associate to development. Of the ten school climate subscales, six added significantly to the prediction of adolescent development. The school social environment, which in this scale is measured by peer interactions, accounted for the most variance in adolescent development. This finding is consistent with existing literature suggesting peers are an important part of development (Deater \& Decker, 1999; Pianta, Hamre, \& Allen, 2012; Steinberg, 2008). Similarly, the next greatest contributor to development was the higher perceived positive student-teacher relationship. This finding is also consistent with other research that suggests the importance of student teacher relationships for adolescent developmental and adjustment outcomes (Eccles \& Roeser, 2011; Roorda, Koomen, Spilt, \& Oort, 2011; Tian, Chen \& Huebner, 2014). The fact that both relationship subscales within school climate associated positively with adolescent development was to be expected since one major component of adolescent development, as measured in this study, is relatedness. Thus opportunities to experience warm, positive relationships should directly satisfy an adolescent's need for relatedness (Deci \& Ryan, 2002). 
The next relatively important school climate subscale was based on the students' perceived exclusion/privilege for predicting adolescent developmental needs satisfaction. This is a relatively new subscale on the school climate measure and has not been heavily researched in existing literature. However, this subscale is designed to indicate whether or not the student perceives the school as favoring some students over others. Although not yet supported directly in the research, it makes sense that the less exclusion, and more inclusion or belongingness a student feels about the school, the more likely they are to feel supported and safe to develop in autonomy, competency and relatedness. Research on belongingness and support within the school environment (Eccles \& Midgley, 1994; Eccles \& Roeser, 2011) seems to indicate this association.

Following the trend of supportive relationships and environments predicting adolescent development, parental involvement was the fourth most important school climate element. The more students indicated that their parents were actively involved with the school, the more likely they were to have higher needs satisfaction in autonomy, competence, and relatedness development. This finding is not surprising, as developmental researchers know how important parents are to healthy adolescent development (Doyle, Brendgen, Markiewicz \& Kamkar, 2003; Hightower, 1990; Luyckx et. al., 2007; Lynch \& Cicchetti, 1997). Specifically, authoritative parents (highly demanding and highly responsive) were significantly successful at protecting their adolescent children from drug use and increasing a sense of competence in their adolescent (Larzele, Morris, \& Harrist, 2013). It is possible this item may be acting as a proxy indicator for parenting relationship overall. However, there is a growing literature suggesting the importance of family-school relationships that suggest parental involvement, and more specifically a positive relationship between the school and an adolescent's parents, can contribute to more positive 
outcomes for the adolescent (Hill \& Tyson, 2009). Further research that controls for the parent relationship, should decipher if parental involvement in the school climate is significantly predictive of adolescent development over and above the parent relationship in general.

Existing research has studied student engagement as part of teacher-student relationships, the current study measures engagement separate from teacher-student relationships. Engagement was the fifth most important predictor of development. It makes sense that when adolescents are fully engaged in the experience of learning, that their autonomy and competence have the opportunity to develop. In fact research has shown associations between autonomy, competence, and school or classroom level engagement (Czikszentmihalyi \& Schneider, 2000; Johnson, Crosnoe, \& Elder, 2001; Marks, 2000). Specifically, researchers found that a student's sense of autonomy and competency increased in school environments that created challenging individual or group learning situations, in which students felt they had the skills to succeed (Shernoff, Csikszentmihalyi, Shneider, \&Shernoff, 2003).

To a much less degree, but still significant, academic support was associated with higher levels of adolescent development. One major aspect of adolescent development, as it was measured in the current study, is competence, or the notion that one has the skills to succeed at a particular task at hand, thus, logically, academic support at the school would contribute to an adolescent's sense of competency (Crosnoe, 2001; Csikzentmihalyi \& Schneider, 2000). Furthermore, research on the implicit messages school environments send students (sometimes referred to in educational research as "hidden curriculum") support the notion that academic support could have an impact on adolescent development. The degree of support shown to an adolescent sends an implicit message from leaders and educational institutions that the students and their educations are valued (Stolp \& Smith, 1995; Titman, 1994). Academic support may 
bolster an early adolescent's satisfaction of the need for competency while also providing a general sense of support to the student. Providing academic support may also support a students' need for autonomy, as they are more and more able to use their academic skills independently.

In conclusion, the significant associations between aspects of school climate and adolescent development were generally expected based on existing literature, but the strength of the current study is looking at the specific elements of school climate and their individual, relative weight in predicting adolescent development. School climate variables explained $32 \%$ of the variance in development which supports the notion that schools are an important context and contribute to adolescent development. Further research in school climate and adolescent development is suggested in two main directions. First, studies investigating the relative contribution of all four major developmental contexts (families, peers, schools, and culture) on adolescent development will more closely capture the ways in which context impacts adolescent development. Hence study designs that measure these contexts in regards to adolescent development will answer important questions about the effect of context. Second, based on the Person-Process-Context-Time Model (Bronfenbrenner, 1994) and other similar theoretical notions, the potential bidirectional relationship between school climate and adolescent development should be further investigated. It could be that the greater sense of developmental needs support a young person experiences, the more prepared or receptive he or she is to the positive elements of the school climate. It may also be that the school climate has the ability to satisfy the early adolescent's developmental needs that are not otherwise being met outside of school. Most likely, it is a combination of both, a bidirectional relationship in which more positive school climates contribute to more positive developmental needs satisfaction and more positive developmental needs satisfaction contributes to more positive perceptions of school 
climates. This type of study would require a longitudinal design that measured perception of school climate and adolescent development at several time points.

\section{Research Question \#2: How are School Climate and Adolescent Development associated with Identity Development?}

Three of the ten School Climate subscales and two of the three adolescent development subscales added significantly to the prediction of identity development. The most significant predictor of positive identity development in the current model was relatedness satisfaction. In other words, the extent to which the adolescent felt a sense of warm and positive relationships with key people in his or her life related to the extent to which a more healthy or positive identity had been formed. This notion is supported by researchers who specifically look at relationships in regards to identity formation (Kroger, Martinussen, \& Marcia, 2010; Lannengrand-Willems \& Bosma, 2006; Luyckx, et. al., 2009). Because SDT theory posits that positive identity formation occurs when developmental needs of autonomy, competence, and relatedness are satisfied (LaGuardia \& Ryan, 2002; 2007), academic support makes logical sense in the sense that it potentially provides students with greater competence which leads them to a greater sense of competent identity. This is particularly reasonable when the specific type of identity development (orientation towards future self) is considered. An integrated, positive identity of what one wants to be in the future is encouraged by academic support. Alarmingly, identity related research in "future possible selves" (Markus \& Nurius, 1986) shows evidence of the negative side of this relationship; when academic support is lacking, positive identity development can suffer. One such example is the finding that students who lacked academic support over time no longer saw attending college as a part of their identity and would withdraw their academic effort (Oyserman, Bybee, \& Terry, 2006). Similarly, parental involvement in the 
school community was another salient feature of positive identity development. Part of identity development relies on the adult role models adolescents come into contact with (Oyserman, Brickman, \& Rhodes, 2007; Hurd, Zimmerman \& Xue, 2009; Kroger, 2008). Consistent with existing research, this finding seems to suggest that the more parents are involved with the adolescent's school, for instance, endorsing or role-modeling pro-academic behavior, the more likely the adolescent is to develop a sense of positive future identity.

Autonomy satisfaction, or the extent to which the young person felt the freedom to make choices based on his or own thoughts, beliefs, and values was also associated with positive identity development in this model. Côté's (2000) work on the relationship between agency (which is a very similar to autonomy in definition) and identity provides support for this finding. Côté (2000) states that because identity development is dependent on exploration, the individual's sense of ability to experiment with different selves and possibilities is key to providing the opportunity for an individual to discover the true identity and self. Items in the current study indicating positive identity development such as, "I am considering a number of different lifestyles that might be good for me," (item number 8) and "My plans for the future match my true values and interests," (item number 16) seem particularly reliant on an individual's autonomy in exploration and decision-making about his or her future.

Finally, a significant negative association was present between school social environment and positive identity development. This particular negative relationship was not expected, however, research to support this finding exists to suggest this is not an unreasonable finding. Eccles et al., (1993) found that social identities, or the ways that students classified themselves in relation to their peers predicted certain risk behaviors, thus providing some support for the notion that perceptions of positive peer relationships do not always directly translate into positive 
identity and developmental choices. Furthermore, research on peer rejection and bullies has made the case that kids who exhibit anti-social aggressive, "bully"-like behaviors, often tend to have social support from peers, particularly like-minded, similarly aggressive peers (Rubin, Bukowski, \& Parker, 2006). So, even though young people are exhibiting more anti-social behaviors that could be linked to maladjustment, they rate peer interactions as generally positive. In a peer rejection study performed at the middle school level, aggressive-rejected students did not differ from average students in behavior or emotional response to such rejection (Parkhurst \& Asher, 1992). Further research investigating the contribution of positive social regard in the school setting on identity should be pursued.

In summary, school climate and adolescent development accounted for $26 \%$ of the variance in positive identity development. Empirical work on identity development suggests, just as with adolescent development, that identity formation happens across contexts and across contextual domains (e.g., sports, physical attractiveness, intimate relationships, and religion; Grotevant, 1984). Although it was expected that more domains of school climate, and all domains of adolescent development would be significantly associated with identity development, it may be the case that the newer measures included in this study (specifically the School Climate Measure and the Dimensions of Identity Development Survey) have not been utilized enough across populations, particularly at the middle school age, to be completely psychometrically indicative of the current study sample. Future research using these measures in a diverse middle school aged population is suggested. 


\section{Research Question \#3: What are the relations between the latent constructs in the hypothesized model and how do they affect adjustment outcomes?}

The goal of this research question was to develop a cohesive and parsimonious conceptual model of the ways in which adolescent development, school environment, and identity formation link to adjustment outcomes. In the present study indicators of adjustment were academic achievement, substance use, and sexual risk factors. This conceptual model was built upon existing theoretical and empirical work. The goal was to integrate what is known across disciplines to more closely model the processes that potentially impact adjustment outcomes for young adolescents. Overall, investigation of the associations across the constructs revealed that school climate and adolescent development were both significantly and positively related to healthy identity development as hypothesized. Extant literature is consistent with these findings as discussed in detail in the sections above (for examples see Grolnick \& Ryan, 1989; Rich \& Schacter, 2012). A drawback of existing research concerning this model is it often examines these paths using regression analyses which operate under the assumption that each association is independent from the other. The strength of the current study is that it links these processes, which are often not modeled together, particularly in early adolescence. Thus, the current study design provides the opportunity to look at the relative contribution of each variable on the adjustment outcomes. Further, Structural Equation Modeling measures and then parses out measurement error which allows us to more closely approximate the latent constructs (Hancock \& Mueller, 2013). Consistent with study hypotheses, positive school climate and adolescent development were associated with positive identity development, which was, in turn, associated with higher academic achievement and lower rates of sexual risk and substance use. In all three models development was associated relatively more than school climate to identity development, 
although parameter estimates were close (see Figures D6, D7, and D8 for details). These findings build upon existing literature because identity development has not been often studied in direct relationship to basic psychological needs satisfaction. At the present, there are no known studies that include both school climate and adolescent development in one model predicting identity. This is an important research direction because the current research study's findings suggest that school climate is a significant piece of an individual's positive developmental trajectory. Findings also suggest that positive school climate shares $32 \%$ of the variance with developmental needs satisfaction, thus linking school climate to more positive adolescent development. Finally, studying adolescent developmental support, with school climate in regards to healthy identity development is not only important because it is understudied, it is important because identity researchers have linked such healthy identity development to positive adjustment outcomes across the lifespan. The current findings seem to indicate that both constructs significantly contribute to identity development. Thus, schools should not be left out of the identity conversation, particularly at the early adolescent stage. Findings suggest that it may be important for middle school professionals to consider ways in which they can promote identity development for early adolescent students.

Not only is this important because we know identity development has a positive impact on adolescents (Steinberg, 2008), but it is also important in the context of this study.

The present study indicated that identity development was significantly associated with substance use (-.41), followed by academic achievement (.33), and sexual risk (-.13). Thus, the present study seems to indicate the value of identity development on positive adjustment outcomes for young people. These findings are particularly inspiring given the fact that identity was significantly associated with positive adjustment outcomes even when SES, race, and 
household configuration were controlled. Such findings provide support for the idea that positive school climates, that satisfy the developmental needs of early adolescents, help the young people they serve develop healthy identity that, in turn, prevents poor adjustment outcomes, regardless of typical factors (such as SES) that professionals tend to see as obstacles. Often educators, and other professionals who work with early adolescents, may become discouraged in the face of what are frequently seen as extremely difficult obstacles for young people to overcome, such as coming from poverty, broken homes, or minority cultures. However, the present study shows how the combination of basic psychological needs support, positive school climate, and healthy identity formation can lead to positive outcomes despite such obstacles.

In summary, analyses suggest that school climate, adolescent development, and identity development work in concert to impact academic achievement, sexual risk, and substance use. Future research should employ a longitudinal design to explore the potential bidirectional nature of these constructs. Additionally, the proposed conceptual models should be investigated in future research in hopes of replicating the findings from this study. These findings, particularly if replicated, could be empowering for people who work with early adolescents and could contribute to policy changes involving mandating more developmentally responsive schools.

\section{Research Question \#4: Are the effects of School Climate and Adolescent Development on}

\section{adjustment outcomes mediated by Identity Development?}

The final research question in this study is based directly on the Self Determination Theory, particularly as it was proposed in the La Guardia and Ryan (2002) book chapter. Whereas it appears there have been no studies that examined the potential mediation of identity development between school climate, adolescent development and adjustment outcomes, the case for such an analysis is made clear in the literature. Self Determination Theory posits several 
relationships that directly relate to the conceptual model in the current study: 1) Individuals are active agents in their development, 2) Contexts provide the necessary support (or not) for the basic psychological and developmental needs of individuals, 3) The satisfaction of the need for autonomy, competency, and relatedness results from the support provided for these constructs, and 4) A person's sense of self (or identity) is either created based on intrinsic, "integrated" (positive, healthy identity development) or extrinsic, "introjected" (negative, maladaptive identity development) ways based on the extent to which his or her needs are satisfied (La Guardia \& Ryan, 2002). The current study builds on this theory by introducing ego identity theory (Erikson, 1968; Marcia, 1980) which makes the case that positive developmental (or adjustment) outcomes are the result of an "achieved" identity status, characterized by high exploration of and high commitment to one's sense of self. It further advances extant literature by using the Dimensions of Identity Development scale (Luyckx et. al., 2007) to measure the developmentally appropriate progress toward such an achieved identity in the adolescent population. Identity significantly and partially mediated the associations between school climate and adolescent development when predicting academic achievement, substance use, and sexual risk. Thus, implications about the importance of identity development can be drawn. The current study seems to provide some evidence that identity may act in a way that solidifies positive development, both in the school context and generally. This solidification may then lead to an adolescent's choices and behaviors that contribute to healthy adjustment outcomes. In summary, this analysis provides empirical support for the theoretical work based on Self-Determination theory done by La Guardia and Ryan (2002). This research question, and the related findings, seem to indicate that the routes to positive identity development, and the specific supports that 
educators and other professionals that work with early adolescents may provide, is an important direction for future research to investigate.

\section{Limitations and Strengths}

There are some limitations associated with this study. First, this study used data from a cross-sectional survey administered to groups of middle school students. Because the study did not follow the students longitudinally or apply experimental methodology, this study does not provide definitive causal evidence. Further, Maxwell and Cole (2007) asserted that for true tests of mediation, data should be collected longitudinally. Second, the sample from this study came from a relatively homogenous population. Most participants identified as Caucasian $(\sim 81 \%)$ with the next highest reporting category identifying as Native American ( 6\%). Additionally, all participants were from three schools located in one county in the state of West Virginia. Therefore, caution should be used when generalizing this study's findings to young people from other ethnic, socioeconomic, cultural, or otherwise dissimilar backgrounds. Third, the instruments used in the current study had some limitations. The Basic Psychological Needs Satisfaction (BPNS) measure was reliable as one factor, but the three subscales had weak Cronbach's alphas which may have created bias in the analyses for research question \#2, which used the BPNS subscales as independent predictors. Fortunately, structural equation modeling corrects for and separates out measurement error, so this was not an issue for analyses associated with research questions \#3 and \#4. Other measurement limitations included the way that observed adjustment outcomes were created. Several items indicating adjustment outcomes were used to create count measures for substance use and sexual risk; although this is often done in studies concerning risk behavior, the particular items selected to indicate each observed variable were selected post-hoc based on the extent to which they hung together in the particular data set, 
and thus bias may have been introduced in the adjustment outcome variables. Fourth, all measures were self-report measures. There are obvious concerns with asking individuals to selfreport on their academic achievement and risk behavior, particularly in a school setting. Every effort was made to assure students that their responses would be kept confidential. The original study design intended to use WVEIS student identification numbers, but due to a miscommunication, several students left this question blank, thus providing limited ability to match survey responses with objective GPA, SES, and attendance data. Future studies should endeavor to use objective data when investigating the associations between the variables in the current study. Finally, a limitation could be the analytical approach. The present study tested for significant mediation using Sobel tests, although these tests are widely used and accepted, it has been more recently suggested that Preacher and Hayes (2008) boot-strapping method be employed as it would be a more robust and effective way of testing for mediation. However, given the extremely low p-values (less than .001 in all three mediation tests), the Preacher and Hayes method would result in very similar findings. Furthermore, although the non-normality of the outcome variables was corrected for using the Satorra-Bentler scaling methods (Hancock \& Mueller, 2013; Satorra \& Bentler, 2001), an alternative and non-parametric approach to analyzing the structural models (for example using logistic or probit regression) was not employed.

Researchers and practitioners can also be confident in these findings for several reasons. This study used a large sample size of approximately 1,500 participants. This sample size allowed for the viability of the analysis strategies employed. It also assured the researcher adequate power for each analysis. Also, this study used data collection procedures that have been used routinely and carefully refined for over 15 years. These data collection procedures have 
been rigorously assessed (Kristjansson, Sigfusson, Sigfusdottir, \& Allegrante, 2013) and were implemented at each school site. Additionally, each instrument included in the current study was carefully selected and compared to other instruments measuring similar constructs. The instruments included in this study were selected based on demonstrated highly psychometric properties and their developmental appropriateness for middle school aged early adolescents.

Despite the limitations, the current study makes a meaningful contribution to the literature on school climate, adolescent development, and identity development in early adolescence.

\section{Key Implications}

Several overarching implications can be drawn from the research findings in the present study. First, this study provides empirical support for Self-Determination Theory in the school context and with early adolescents, suggesting that the main constructs of this theory are interdependent and linked to positive outcomes for young people. Second, this study provides further evidence for the notion that positive development can be supported by external forces such as school climate and the internal and external forces that contribute to the satisfaction of one's autonomy, competence, and relatedness needs. Taken together, these findings imply development is a process that occurs across contexts, and although obstacles may arise, with the right environments and support, young people can overcome these obstacles.

Additionally, findings from this study support the notion that healthy identity development is an integral piece to positive adjustment in early adolescents. Although 11-14 year olds should not yet have a fully achieved sense of identity, the process of exploring the future and imagining positive possible selves partially mediates the associations between developmental support and adjustment outcomes. Although researchers know identity is 
important and contributes to positive development (Kroger, 2008), no known studies at the time of this dissertation have looked at the associations and mediations between development, school climate, and positive adjustment. Thus, researching how to specifically support identity development, both for parents and educators, seems to be an important next step in both educational and developmental research.

Finally, an important implication from this study is the notion that schools matter. Schools have a significant influence on an early adolescent's developmental trajectory. Both educational professionals, as well as policy makers, need to understand the importance of focusing on the developmental needs, not just the academic needs, of young people. Schools and teachers cannot be effective if solely focused on academic outcomes (Zins, Bloodworth, Weissberg, \& Walberg, 2004). This may mean a need for wide educational reform in the way of a shift away from the current academic content focus in schools. Currently, American public schools are partially funded (or not) based on performance on standardized testing. If our ultimate goal in American education is to create fully developed positively contributing citizens we are currently missing the mark with a focus on high-stakes testing linked solely to academic content-specific outcomes. Perhaps schools should be supported in their pursuit of and incentivized to create more developmentally responsive environments rather than simply helping a large percentage of students score "proficient or advanced" in Math and English Language Arts. Findings from the current study provide some support for the ability for developmentally responsive schools (those that give students a myriad of opportunities to explore possibilities, relate positively to others, and take on safe challenges) to be greatly beneficial for early adolescents, over and above the impacts of SES, household configuration, or race. Of course, 
these findings should be replicated, but more effective directions for educational policy can be gleaned from these initial findings.

\section{Future directions}

First, future research in West Virginia public schools will continue in a longitudinal partnership with several counties. This work is partially made possible by AWARE grant funding. The author of this study, in conjunction with the ICE collaborative research team, will continue to collaborate with schools and communities in West Virginia to promote best practices and developmentally responsive approaches to supporting the best interest of young people. This continued research will include longitudinal and qualitative work in its research design.

Second, future research should include family, community, and peer influences on the developmental trajectory toward positive adjustment. Including these other major developmental influences in the model will more closely approximate the true phenomena and processes occurring in the development of young people. It will also allow researchers to investigate the relative contribution that each of these influences has on an early adolescent's developmental outcomes. Additionally, comparing the developmental trajectories of early and older adolescents would be important. The potentially different developmental timing and relative contribution of the major developmental influences on identity development and adjustment outcomes is important in order to determine the specific and necessary supports to provide across contexts and ages to young people.

Finally, there are several quantitative analytical approaches that could investigate the associations between the main constructs in interesting and illuminating ways. Further research in this area should include the use of Discriminant Function analysis, which would allow for a clearer look at the risk behavior outcomes in a binary lens. Cluster Analysis techniques would 
also allow for multi-group comparisons across identity or school climate "typologies" creating a "profile" or "type" of identity status or school climate perception which could then be applied to the study of developmental trajectory or related adjustment outcomes.

In conclusion, findings suggest that schools and professionals who work with young adolescents should be aware of the ways in which they can support the satisfaction of autonomy, relatedness, and competency in order to promote healthy identity development leading to positive adjustment. The current research provides compelling support for the importance of developmental support in a school-based context. Implications for school-based interventions crafted to prevent risky behavior can be elicited from the more holistic understanding of the mechanisms at play. Finally, and notably, this study highlights the importance of identity development as the mechanism that cements contextual and individual factors together that may lead to positive adjustment or maladjustment in later life, which definitely contributes to existing identity literature. 


\section{References}

Adams, C. M. \& Forsyth, P. B. (2009). The nature and function of trust in schools. Journal of School Leadership, 19(2), 126-153.

Adie, J.W., Duda, J.L., \& Ntoumanis, N. (2008). Autonomy support, basic need satisfaction and the optimal functioning of adult male and female sport participants: A test of basic needstheory. Motivation and Emotion, 32(3), 189-199.

Ainsworth, M. D. S. (1979). Infant-mother attachment. American Psychologist, 34, 932-937.

Allen, J. \& Land, D. (1999). Attachment in adolescence. In J. Cassidy \& P. Shaver (Eds.), Handbook of attachment (pp. 319-335). New York: Guilford.

Amorose, A.J. (2007). Coaching effectiveness. In M.S. Hagger \& N.L.D. Chatzisarantis (Eds.), Intrinsic motivation and self-determination in exercise and sport (pp. 209-227). Leeds: Human Kinetics.

Anderman, E. M. (2002). School effects on psychological outcomes during adolescence. Journal of Educational Psychology, 94, 795-809.

Arnett, J. J. (1999). Adolescent storm and stress: Reconsidered. The American Psychologist, 54, $317-326$.

Arnett, J. J. (2000). Emerging adulthood: A theory of development from the late teens through the twenties. American Psychologist, 55, 469-480.

Arnett, J. J. (2013). Adolescence and emerging adulthood: A cultural approach (5th ed.). Upper Saddle River, NJ: Prentice Hall.

Asarnow, J. R., Jaycox, L. H., Duan, N, LaBorde, A. P., Rea, M. M., Tang, L., ...\& Wells, K. B. (2005). Depression and role impairment among adolescents in primary care clinics. Journal of Adolescent Health, 37, 477-483. 
Assor, A., Kaplan, H., \& Roth, G. (2002). Choice is good, but relevance is excellent: Autonomyenhancing and suppressing teacher behaviours predicting students' engagement in schoolwork. British Journal of Educational Psychology, 72, 261-278.

Bandura A. Social Learning Theory. Englewood Cliffs, NJ: Prentice Hall; 1997.

Baron, R. M., \& Kenny, D. A. (1986). The moderator-mediator variable distinction in social psychological research: Conceptual, strategic, and statistical considerations. Journal of Personality and Social Psychology, 51, 1173-1182.

Battistich, V., \& Hom, A. (1997). The relationship between students' sense of their school as a community and their involvement in problem behaviors.American journal of public health,87(12), 1997-2001.

Bausch, C.E. (2010). Healthier Students Are Better Learners: A Missing Link in School Reforms to Close the Achievement Gap. Equity Matters: Research Review No. 6. New York: Columbia University.

Baumrind, D. (1991). The influence of parenting style on adolescent competence and substance use.The Journal of Early Adolescence,11(1), 56-95.

Bear, G., Yang, C., Pell, M. \& Gaskins, C. (2014). Validation of a brief measure of teacher's perceptions of school climate: relations to student achievement and suspensions.

Berman, S. L., Weems, C. F., \& Stickle, T. R. (2006). Existential anxiety in adolescents: Prevalence, structure, association with psychological symptoms and identity development. Journal of Youth and Adolescence, 35(3), 285-292.

Black, A.E., \& Deci, E.L. (2000). The effects of instructors' autonomy support and students' autonomous motivation on learning organic chemistry: A self-determination theory perspective. Science Education, 84(6), 740-756. 
Bosma, H. (2001). Determinants and mechanisms in ego identity development: A review and synthesis. Developmental Review, 21(1), 39-66. doi:10.1006/drev.2000.0514

Bowlby, J. (1969). Attachment and loss: Attachment (Vol. 1). New York: Basic Books.

Bronfenbrenner, U. (1979). The ecology of human development: Experiments in nature and design. Cambridge, MA: Harvard University Press.

Bronfenbrenner, U. (1989). Ecological systems theory. In R. Vasta (Ed.), Annals of child development, Vol. 6 (pp. 187-249). Greenwich, CT: JAI Press.

Bronfenbrenner, U. (1994). Ecological Models of Human Development. International Encyclopedia of Education. Elsevier Sciences, Ltd. 1643-1647.

Bronfenbrenner, U., \& Morris, P. A. (2006). The bioecological model of human development. Handbook of child psychology.

Brophy, J. (2008). Developing students' appreciation for what is taught in school. Educational Psychologist, 43, 132-141.

Browne, M.W., \& Cudeck, R. (1993). Alternative Ways of Assessing Model Fit. In K.A. Bollen \& J.S. Long (Eds.), Testing Structural Equation Models (pp.136-162). Thousand Oaks, CA: Sage Publication, Inc.

Carlson, S.A, Fulton J.E, Lee, S.M, Maynard, M., Drown, D.R., Kohl III, H.W., Dietz, W.H. (2008). Physical education and academic achievement in elementary school: data from the Early Childhood Longitudinal Study. American Journal of Public Health, 98(4):721727.

Carr, S., \& Wyon, M. (2003). The impact of motivational climate on dance students' achievement goals, trait anxiety, and perfectionism. Journal of Dance Medicine \& Science, 7(4), 105-114. 
Centers for Disease Control and Prevention. (2009). School connectedness: Strategies for increasing protective factors among youth. Retrieved from http://www.cdc.gov/ HealthyYouth/AdolescentHealth/pdf/connectedness.pdf

Center for Disease Control and Prevention (2014a). Adolescent and School health. Youth risk behavior surveillance system. Retrieved from: http://www.cdc.gov/ HealthyYouth/yrbs/index.htm?s_cid=tw_cdc16

Centers for Disease Control and Prevention. (2014b). Sexual risk behaviors and academic achievement. Retrieved from http://www.cdc.gov/healthyyouth/health_and_academics/ pdf/sexual_risk_behaviors.pdf

Chapman, R. L., Buckley, L., Reveruzzi, B., \& Sheehan, M. (2014). Injury prevention among friends: The benefits of school connectedness. Journal of Adolescence, 37(6), 937-944. doi:10.1016/j.adolescence.2014.06.009

Chirkov, V. \& Ryan, R. (2001). Parent and teacher autonomy-support in Russian and U.S. Adolescents: Common effects on well-being and academic motivation. Journal of CrossCultural Psychology, 32 (5), 618-635.

Clark, H. K., Ringwalt, C. L., Shamblen, S. R., Hanley, S. M., \& Flewelling, R. L. (2011). Are substance use prevention programs more effective in schools making adequate yearly progress? A study of Project Alert *. Journal of Drug Education, 41(3), 271-288.

Cohen, J. (1992). A power primer. Psychological bulletin,112(1), 155.

Coker, J., \& Borders, L. (2001). An analysis of environmental and social factors affecting adolescent prob- lem drinking. Journal of Counseling \& Development, 79, 200-208 
Connolly, J., Furman, W., \& Knoarski, R. (2000). The role of peers in the emergence of heterosexual romantic relationships in adolescence. Child Development, 71 (5), 13951408.

Côté, J. E. (2000). Arrested adulthood: The changing nature of maturity and identity. New York: New York University of Press.

Côté, J. E., \& Schwartz, S. J. (2002). Comparing psychological and sociological approaches to identity: identity status, identity capital, and the individualization process. Journal of Adolescence, 25(6), 571-586. doi:10.1006/jado.2002.0511

Csikszentmihalyi, M., \& Schneider, B. (2000). Becoming adult: How teenagers prepare for the world of work. New York: Basic Books.

Dahl, R.E. (2001). Affect regulation, brain development, and behavioral/emotional health in adolescence. CNS Spectrum, 6, 1-12.

Deater-Deckard, K. (2001). Annotation: Recent research examining the role of peer relationships in the development of psychopathology. Journal of child psychology and psychiatry, and allied disciplines, 42(5), 565-79. Retrieved from http://www.ncbi.nlm.nih.gov/pubmed/11464962

Deci, E. L. (1975). Intrinsic motivation. New York: Plenum Press.

Deci, E. L., \& Ryan, R. M. (1985). Intrinsic motivation and self-determination in human behavior. New York: Plenum Press.

Deci, E. L., \& Ryan, R. M. (2000). The "what" and "why" of goal pursuits: Human needs and the self-determination of behavior. Psychological Inquiry, 11, 227-268.

Delamont, S. (2012). Sex roles and the school. Routledge. 
Dewey, J. (1916). Democracy and Education. An introduction to the philosophy of education, New York: Free Press.

Dewey, J. (1938) Experience and Education, New York: Collier Books. (Collier edition first published 1963).

Doyle, A. B., Brendgen, M., Markiewicz, D., \& Kamkar, K. (2003). Family relationships as moderators of the association between romantic relationships and adjustment in early adolescence. The Journal of Early Adolescence, 23(3), 316-340.

Drolet, M., Arcand, I., Ducharme, D., \& Leblanc, R. (2013). The sense of school belonging and implementation of a prevention program: Toward healthier interpersonal relationships among early adolescents. Child and Adolescent Social Work Journal, 30, 535-551. doi:10.1007/s10560-013-0305-5

Duncan, Arne (2009). The FY 2009 Summary of Performance and Financial Information. United States Department of Education. Retreived from: http:/www2.ed.gov/about/reports/ annual/2009report/summary.pdf

Duriez, B., Luyckx, K., Soenens, B. and Berzonsky, M. (2012), A Process-Content Approach to Adolescent Identity Formation: Examining Longitudinal Associations Between Identity Styles and Goal Pursuits. Journal of Personality, 80: 135-161.

Eccles, J. S., Midgley, C., Wigfield, A., Buchanan, C. M., Reuman, D.,Flanagan, C., \& MacIver, D. (1993). Development during adolescence: The impact of stage- environment fit on adolescents' experiences in schools and families. American Psychologist, 48, 90 -101

Eggert, L. L., Thompson, E. A., Herting, J. R., Nicholas, L. J., \& Dicker, B. G. (1994). Preventing adolescent drug abuse and high school dropout through an intensive school- 
based social network development program. American Journal of Health Promotion, $8(3), 202-215$.

Eichas, K., Meca, A., Montgomery, M., \& Kurtines, W. (2014). Identity and Positive Youth Development: Advances in Developmental Intervention Science. Oxford Handbooks Online. Retrieved 21 Jul. 2014, from http://www.oxfordhandbooks.com/ view/ 10.1093/oxfordhb/9780199936564.001.0001/oxfordhb-9780199936564-e-020.

Eisenberg, N., Morris, A. S., McDaniel, B., \& Spinrad, T. L. (2009). Moral cognitions and prosocial responding in adolescence. Handbook of adolescent psychology.

Engberg, J., \& Morral, A. R. (2006). Reducing substance use improves adolescents' school attendance. Addiction, 101, 1741-1751. doi:10.1111/j.1360-0443.2006.01544.x

Erikson, E. H. (1959) Identity and the Life Cycle. New York: International Universities Press. Erikson, E. H. (1968) Identity, Youth and Crisis. New York: Norton.

Faircloth, B. S. (2012). "Wearing a mask" vs. connecting identity to learning. Contemporary Educational Psychology, 37, (3), 195-205.

Ferrer-Wreder, L., Palchuk, A., Poyrazli, S., Small, M., \& Domitrovich, C. (2008). Identity and adolescent adjustment. Identity : An International Journal of Theory and Identity and Adolescent Adjustment, 8(2), 95-105.

Flum, H., \& Kaplan, A. (2012). Identity formation in educational settings: A contextualized view of theory and research in practice. Contemporary Educational Psychology, 37(3), 240245. doi:10.1016/j.cedpsych.2012.01.003

Ford, J. A. (2009). Nonmedical prescription drug use among adolescents the influence of bonds to family and school. Youth \& Society, 40(3), 336-352.

Freire, P. (1986). Pedagogy of the oppressed. New York: Continuum, 1986. 
Gadin, K. G., \& Hammarstrom, A. (2005). Youth health a possible contributor to the higher degree of girls reporting psychological symptoms compared with boys in grade nine? European Journal of Public Health, 15(4), 380-385. doi:10.1093/eurpub/cki097

Giannotta, F., \& Özdemir, M. (2013). School bonding and alcohol use in Italian early adolescents: What comes first? Merrill-Palmer Quarterly, 59(3), 280-303.

Gilligan, C. (1982). In a Different Voice. Cambridge, MA: Harvard University Press.

Goodenow, C. (1992). Strengthening the links between educational psychology and the study of social contexts. Educational Psychologist, 27(2), 177-196.

Gottfredson, G. D., Gottfredson, D. C., Payne, A. A., \& Gottfredson, N. C. (2005). School climate predictors of school disorder: Results from a national study of delinquency prevention in schools. Journal of Research in Crime \& Delinquency, 42, 412-444.

Grolnick, W. S., \& Ryan, R. M. (1989). Parent styles associated with children's self-regulation and competence in school. Journal of educational psychology,81(2), 143.

Grotevant, H. D. (1987). Toward a process model of identity formation. Journal of Adolescent Research, 2, 203-222.

Hall, G.S. (1904). Adolescence: Its psychology and its relation to physiology, anthropology, sociology, sex, crime, religion and education (Vols. 1 \&2). Englewood Cliffs, NJ: Prentice Hall.

Hancock, G.R. \& Mueller, R.O. (2013). Structural equation modeling: A second course (2 $2^{\text {nd }}$ edition). Charlotte, NC: Information Age Publishing.

Hanson, T. L., Austin, G., \& Lee-Bayha, J. (2004). Ensuring that no child is left behind: How are student health risks and resilience related to the academic progress of schools? San Francisco: WestEd. 
Harrell, A. W., Mercer, S. H., \& DeRosier, M. E. (2008). Improving the Social-Behavioral Adjustment of Adolescents: The Effectiveness of a Social Skills Group Intervention. Journal of Child and Family Studies, 18(4), 378-387.

Harris, K. M., Duncan, G. J., \& Boisjoly, J. (2002). Evaluating the role of "Nothing to Lose" attitudes on risky behavior in adolescence. Social Forces, 80(3), 1005-1039.

Harter, S. (1999). The construction of the self. New York: Guilford.

Hawkins, J. D., \& Weis, J. G. (1985). The social development model: An integrated approach to delinquency prevention. The Journal of Primary Prevention, 6, 73-97.

Henry, K. L., Knight, K. E., \& Thornberry, T. P. (2012). School disengagement as a predictor of dropout, delinquency, and problem substance use during adolescence and early adulthood. Journal of Youth and Adolescence, 41(2), 156-66. doi:10.1007/s10964-011$9665-3$

Henry, K. L. (2010). Academic achievement and adolescent drug use: An examination of reciprocal effects and correlated growth. Journal of School Health, 80(1), 38-43.

Henry, K. L., \& Slater, M. D. (2007). The contextual effect of school attachment on young adolescents' alcohol use. Journal of School Health, 77(2), 67-75.

Hightower, E. (1990). Adolescent interpersonal and familial precursors of positive mental health at midlife. Journal of Youth and Adolescence, 19, 257-275.

Hill, N. E., \& Tyson, D. F. (2009). Parental involvement in middle school: a meta-analytic assessment of the strategies that promote achievement. Developmental psychology, 45(3), 740.

Hiller-Sturmhofel, S., \& Swartzwelder, H. S. (2004). Alcohol's effects on the adolescent brain: what can be learned from animal models. Alcohol Research and Health, 28(4), 213. 
Hingson, R. W., Heeren, T., \& Winter, M. R. (2006). Age at drinking onset and alcohol dependence: age at onset, duration, and severity. Archives of pediatrics \& adolescent medicine, 160(7), 739-746.

Hoy, W. (2014). School Climate. Retrieved August 5, 2014, from http://www.waynekhoy.com/ research_and_scholarship.html

Hoy, W. K., \& Hannum, J. W. (1997). Middle School Climate: An Empirical Assessment of Organizational Health and Student Achievement. Educational Administration Quarterly, 33 (3 ), 290-311. doi:10.1177/0013161X97033003003

Hoy, W. K. \& Miskel, C. G. (2013). Educational administration: Theory, research, and practice, 9th edition. New York: McGraw-Hill.

Hoyle, R. H. (1995). The structural equation modeling approach: Basic concepts and fundamental issues. In Structural equation modeling: Concepts, issues, and applications, R. H. Hoyle (editor). Thousand Oaks, CA: Sage Publications, Inc., pp. 1-15.

Hu, L. \& Bentler, P. M. (1999). Cutoff criteria for fit indexes in covariance structure analysis: Conventional criteria versus new alternatives. Structural Equation Modeling, 6(1), 1-55.

Hurd, N. M., Zimmerman, M. A., \& Xue, Y. (2009). Negative adult influences and the protective effects of role models: A study with urban adolescents. Journal of youth and adolescence, 38(6), 777-789.

Jang, H., Reeve, J., \& Deci, E. L. (2010). Engaging students in learning activities: It is not autonomy support or structure but autonomy support and structure. Journal of Educational Psychology, 102(3), 588.

Jamal, F., Fletcher, A., Harden, A., Wells, H., Thomas, J., \& Bonell, C. (2013). The school environment and student health: a systematic review and meta-ethnography of qualitative 
research. BMC Public Health, 13(1), 798-811. doi:10.1186/1471-2458-13-798

Jessor, R. \& Jessor, S. (1977). Problem behavior and psychosocial development: A longitudinal study of youth. New York: Academic Press.

Johnson, M. K., Crosnoe, R., \& Elder, G. H., Jr. (2001). Students' attachment and academic engagement: The role of race and ethnicity. Sociology of Education, 74, 318-340.

Kaplan, A., \& Flum, H. (2012). Identity formation in educational settings: A critical focus for education in the 21st century. Contemporary Educational Psychology, 37(3), 171-175. doi:10.1016/j.cedpsych.2012.01.005

Klein, J. D. (1997). The National Longitudinal Study on Adolescent Health: Preliminary resultsgreat expectations. Journal of the American Medical Association, 278, 864-865.

Kline, R. B. (2010). Principles and Practice of Structural Equation Modeling. New York: The Guilford Press.

Kohlberg, L. (1966). A cognitive-development analysis of children's sex-role concepts and attitudes. In E. E. Maccoby (Ed.), The development of sex differences (pp. 72-81). Stanford: Stanford University Press. Köller,

Kohlberg, L. (1981). Essays on Moral Development, Vol. I: The Philosophy of Moral Development. San Francisco, CA: Harper \& Row.

Kristjansson, A. L., Sigfusson, J., Sigfusdottir, I. D., Allegrante, J. P. (2013). Data collection procedures for school-based surveys among adolescents: The Youth in Europe study. Journal of School Health, 83, 662-667.

Kroger, J. (2000). Identity development: Adolescence through adulthood. Newbury Park, CA: Sage.

Kroger, J. (2008). Identity development during adolescence. In G. R. Adams \& M. D. Berzonsky 
(Eds.), Blackwell Handbook of Adolescence. Oxford, UK: Blackwell Publishing Ltd.

Kroger, J., Martinussen, M., \& Marcia, J. E. (2010). Identity status change during adolescence and young adulthood: a meta-analysis. Journal of Adolescence, 33(5), 683-98.

La Guardia, J. G., \& Ryan, R. M. (2007). Why identities fluctuate: Variability in traits as a function of situational variations in autonomy support. Journal of Personality, 75(6), 1205-1228.

La Guardia, J., \& Ryan, R. (2002). What adolescents need. Academic motivation of adolescents, $2,193$.

Lannegrand-Willems, L., \& Bosma, H. A. (2006). Identity development-in-context: The school as an important context for identity development. Identity : An International Journal of Theory and Research, 6(1), 85-113.

Larson, R. (2000). Toward a Psychology of Positive Youth Development. American Psychologist, 55 (1), 170-183.

Larzelere, R. E., Morris, A. S. E., \& Harrist, A. W. (2013). Authoritative parenting: Synthesizing nurturance and discipline for optimal child development. American Psychological Association.

Leadbeater, B. J. \& Way, N. (2001) Growing up fast: Early adult transitions of inner-city adolescent mothers. Mahwah, NJ: Erlbaum

Lee, V. E., \& Burkham, D. T. (2000). Dropping out of high school: The role of school organization and structure. In conference proceedings: Dropouts in America : How severe is the problem?, 1-41.

Legewie, J., \& DiPrete, T. A. (2012). School context and the gender gap in educational achievement. American Sociological Review, 77(3), 463-485. 
Libbey, H. (2004). Measuring student relationships to school: Attachment, bonding, connectedness, and engagement. Journal of School Health, 74, 274-283

Luyckx, K., Goossens, L. Soenens, B. \& Beyers, W. (2006). Unpacking commitment and exploration: Validation of an integrative model of adolescent identity formation. Journal of Adolescence, 29,361-378.

Luyckx, K., Schwartz, S., Berzonsky, M.D., Soenens, B., Vansteenkiste, M., Smits, I., \& Goossens, L. (2007). Capturing ruminative exploration: Extending the four-dimensional model of identity formation in late adolescence. Journal of Research in Personality, 42, $58-82$

Luyckx, K., Soenens, B., Vansteenkiste, M., Goossens, L., \& Berzonsky, M. (2007). Parental psychological control and dimensions of identity formation in emerging adulthood. Journal of Family Psychology, 21, 546-550.

Luyckx, K., Vansteenkiste, M., Goossens, L., \& Duriez, B. (2009). Basic need satisfaction and identity formation: Bridging self-determination theory and process-oriented identity research. Journal of Counseling Psychology, 56, 276-288.

Lynch, M., \& Cicchetti, D. (1997). Children's relationships with adults and peers: An examination of elementary and junior high school students. Journal of School Psychology, 35, 81-99

Ma, X., \& Klinger, D.A. (2000). Hierarchical linear modeling of student and school effects on academic achievement. Canadian Journal of Education, 25, 41-55.

MacKinnon, D. P., Warsi, G., \& Dwyer, J. H. (1995). A simulation study of mediated effect measures. Multivariate Behavioral Research, 30, 41-62. 
MacNeil, A.J., Prater, D.L., \& Busch, S. (2009). The effects of school culture and climate on student achievement. International Journal of Leadership in Education, 12 (1), 73-84.

Mann, M. J., Kristjansson, A. L., Sigfusdottir, I. D. \& Smith, M.L. (2013). The Influence of Negative Life Events on Adolescent Depression, Anxiety, and Anger: Comparing the Relative Vulnerability of Early, Middle, and Late Adolescents. In Press.

Marcia, J. E. (1966). Development and validation of ego-identity status. Journal of Personality and Social Psychology, 3, 551-558.

Marcia, J. E. (1980). Identity in adolescence. In Handbook of Adolescent Psychology, 159-187.

Marks, H. M. (2000). Student engagement in instructional activity: Patterns in the elementary, middle, and high school years. American Educational Research Journal, 37, 153-184.

Markus, H. R., \& Nurius, P. (1986). Possible selves. American Psychologist, 41, 954-969.

Masten, A., Coatsworth, J., Neemann, J. Gest, S., Tellegen, A., \& Garmezy, N. (1995). The structure and coherence of competence from childhood through adolescence. Child Development, 66, 1635-1659.

Maxwell, S. E., \& Cole, D. A. (2007). Bias in cross-sectional analyses of longitudinal mediation. Psychological Methods, 12, 23-44.

Maxwell, S. E., Cole, D. A., \& Mitchell, M. A. (2011). Bias in cross-sectional analyses of longitudinal mediation: Partial and complete mediation under an autoregressive model, Multivariate Behavioral Research, 46, 816-841 McMahan, I. (2009). Adolescence. Boston, MA: Pearson Education.

McMahan, I., (2009). Adolescence. Boston, MA: Pearson Education. 
McNeely, C., Nonnemaker, J., \& Blum, R. (2002). Promoting school connectedness: Evidence from the National Longitudinal Study of Adolescent Health. Journal of School, 72(4), $138-146$.

Meeus, W., van de Schoot, R., Keijsers, L., \& Branje, S. (2012). Identity statuses as developmental trajectories: A five-wave longitudinal study in early-to-middle and middle-to-late adolescents. Journal of youth and adolescence,41(8), 1008-1021.

Mollborn, S., Domingue, B. W., \& Boardman, J. D. (2014). Norms as group-level constructs: investigating school-level teen pregnancy norms and behaviors. Social Forces, 93(1), $241-267$.

Muthén, L. K., \& Muthén, B. O. (1998-2012). Mplus user's guide (7 ${ }^{\text {th }}$ Ed.). Los Angeles, CA: Muthén \& Muthén.

Nakkula, M. J., \& Toshalis, E. (2006). Understanding youth: Adolescent development for educators. Cambridge, MA: Harvard Education Press.

National Center for Educational Statistics. (2015) Current Surveys. Retreived from: http://nces.ed.gov/surveys/

National School Climate Council. (2007). The School Climate Challenge: Narrowing the gap between school climate research and school climate policy, practice guidelines and teacher education policy. Available at: http://www.schoolclimate.org/climate/documents/ policy/school-climate-challenge-web.pdf

Niemiec, C. P., \& Ryan, R. M. (2009). Autonomy, competence, and relatedness in the classroom Applying self-determination theory to educational practice. Theory and Research in Education, 7(2), 133-144.

Niehaus, S. K., Rudasill, K. M., \& Rakes, C. (2012). A longitudinal study of school 
connectedness and academic outcomes across sixth grade. Journal of School Psychology, $50,443-460$.

Noom, M.J., Dekovic, M., \& Meeus, W. (2001). Conceptual analysis and measurement of adolescent autonomy. Journal of Youth and Adolescence, 30(5), 577-595.

Oliveira-Campos, M., Giatti, L., Malta, D., \& Barreto, S. (2013). Annals of epidemiology contextual factors associated with sexual behavior among Brazilian adolescents. Annals of Epidemiology, 23(10), 629-635. doi:10.1016/j.annepidem.2013.03.009

Osterman, K. F. (2000). Students' Need for Belonging in the School Community. Review of Educational Research (Vol. 70, pp. 323-367). doi:10.3102/00346543070003323

Oyserman, D., Brickman, D., \& Rhodes, M. (2007). School success, possible selves and parent school-involvement. Family Relations, 56, 479-489.

Oyserman, D., Bybee, D., \& Terry, K. (2006). Possible selves and academic outcomes: How and when possible selves impel action. Journal of Personality and Social Psychology, 91, 188-204.

Patrick, B. C., Skinner, E. A., \& Connell, J. P. (1993). What motivates children's behavior and emotion? Joint effects of perceived control and autonomy in the academic domain. Journal of Personality And Social Psychology, 65(4), 781-791.

Parker, A. K. (2009). Journal of Research in Childhood Education Elementary Organizational Structures and Young Adolescents ' Self-Concept and Classroom Environment Perceptions Across the Transition to Middle School Elementary Organizational Structures and Young Adolescents ', (March 2013), 37-41.

Parkes, A., Waylen, A., Sayal, K., Heron, J., Henderson, M., Wight, D., \& Macleod, J. (2014). Which behavioral, emotional and school problems in middle-childhood predict early 
sexual behavior? Journal of Youth and Adolescence, 43, 507-527.

Parkhurst, J. T., \& Asher, S. R. (1992). Peer rejection in middle school: Subgroup differences in behavior, loneliness, and interpersonal concerns. Developmental Psychology, 28(2), 231.

Pianta, R. C., Hamre, B. K., \& Allen, J. P. (2012). Teacher-student relationships and engagement: Conceptualizing, measuring, and improving the capacity of classroom interactions. In Handbook of research on student engagement (pp. 365-386). Springer US.

Pietarinen, J., Soini, T., \& Pyhalto, K. (2014). Students' emotional and cognitive engagement as the determinants of well-being and achievement in school. International Journal of Educational Research, 67, 40-51.

Powell, K. (2006). How does the teenage brain work? Nature, 442(August), 865-868.

Preacher, K.J. \& Hayes, A. F. (2008). "Asymptotic and resampling strategies for assessing and comparing indirect effects in multiple mediator models". Behaviour Research Methods 40(3), 879-891.

Quested, E., \& Duda, J.L. (2009). Perceptions of the motivational climate, need satisfaction, and indices of well- and ill-being among hip hop dancers. Journal of Dance Medicine and Science, 13(1), 10-19.

Quested, E. \& Duda, J.L. (2010). Exploring the social-environmental determinants of well- and ill-being in dancers: A test of Basic Needs Theory. Journal of Sport \& Exercise Psychology, 32, 39-60.

Raffaelli, M., \& Crockett, L. J. (2003). Sexual risk taking in adolescence: The role of selfregulation and attraction to risk. Developmental Psychology, 39, 1036-1046. doi: 10.1037/0012-1649.39.6.1036 
Reeve, J. (2006). Teachers as facilitators: What autonomy-supportive teachers do and why their students benefit. The Elementary School Journal, 106(3), 225-238.

Reeve, J., \& Jang. H. (2006). What teachers say and do to support students' autonomy during a learning activity. Journal of Educational Psychology, 98(1), 209-218.

Reeve, J., Jang, H., Carrell, D., Jeon, S., \& Barch, J. (2004). Enhancing students' engagement by increasing teachers' autonomy support. Motivation and Emotion, 28, 147-169.

Roeser, R., Strobel, K. R., \& Quihuis, G. (2002). Studying early adolescents’ academic motivation, social-emotional functioning, and engagement in learning: Variable- and person-centered approaches. Anxiety, Stress, and Coping, 15, 345-368.

Reinboth, M., \& Duda, J.L. (2006). Perceived motivational climate, need satisfaction and indices of well-being in team sports: A longitudinal perspective. Psychology of Sport and Exercise, 7(3), 269-286.

Resnick, M. D., Bearman, P. S., Blum, R. W., Bauman, K. E., Harris, K. M., Jones, J., et al. (1997). Protecting adolescents from harm: Findings from the National Longitudinal Study on Adolescent Health. Journal of the American Medical Association, 278, 823832. doi:10.1001/jama.278.10.823.

Rich, Y., \& Schachter, E. P. (2012). High school identity climate and student identity development. Contemporary Educational Psychology, 37(3), 218-228. doi:10.1016/j.cedpsych.2011.06.002

Rigdon, E. E. (1998). Structural equation modeling. In Modern methods for business research, G. A. Marcoulides (editor). Mahwah, NJ: Lawrence Erlbaum Associates, Publishers, 251294. 
Roeser, R., Eccles, J., \& Sameroff, A. (2000). School as a Context of Early Adolescents' Academic and Social-Emotional Development: A Summary of Research Findings. The Elementary School Journal, 100(5), 443-471.

Roorda, D. L., Koomen, H. M., Spilt, J. L., \& Oort, F. J. (2011). The influence of affective teacher-student relationships on students' school engagement and achievement a metaanalytic approach. Review of Educational Research, 81(4), 493-529.

Rubin K.H, Bukowski W., Parker J.G. (2006). Peer interactions, relationships, and groups. In: Eisenberg N, editor. Handbook of Child Psychology: Vol 3 Social, Emotional, and Personality Development. New York: Wiley; 2006; pp. 571-645

Ryan, R. M., \& Deci, E. L. (2000). Self-determination theory and the facilitation of intrinsic motivation, social development, and well-being. American Psychologist, 55, 68-78.

Ryan, R. M., \& Deci, E. L. (2001). On happiness and human potentials: A review of research on hedonic and eudaimonic well-being. Annual Review of Psychology, 52, 141-166.

Ryan, R. M., Deci, E. L., Grolnick, W. S., \& La Guardia, J. G. (2006). Autonomy, relatedness, and the self: Their relation to development and psychopathology. In D. Cicchetti \& D. J. Cohen (Eds.), Developmental psychopathology: Vol. 1. Theory and methods (pp. 618655). New York: Wiley \& Sons.

Ryan, R. M., \& Frederick, C. M. (1997). On energy, personality, and health: Subjective vitality as a dynamic reflection of well-being. Journal of Personality, 65, 529-565.

Ryan, R. M., \& La Guardia, J. G. (2000). What is being optimized?: Self-determination theory and basic psychological needs. In S. Qualls \& R. Abeles (Eds.), Psychology and the aging revolution: How we adapt to longer life (pp. 145-172). Washington, DC: APA Books. 
Ryan, R. M., \& Lynch, J. (1989). Emotional autonomy versus detachment: Revisiting the vicissitudes of adolescence and young adulthood. Child Development, 60, 340-356.

Ryan, R. M., \& Solky, J. A. (1996). What is supportive about social support? On the psychological needs for autonomy and relatedness. In G. R. Pierce, B. R. Sarason, \& I. G. Sarason (Eds.), Handbook of social support and the family (pp. 249-267). New York: Plenum Press.

Ryan, R. M., Stiller, J. D., \& Lynch, J. (1994). Representations of relationships to teachers, parents, and friends as predictors of academic motivation and self-esteem. Journal of Early Adolescence, 14, 226-249.

Saewyc, E. M., Taylor, D., Homma, Y., \& Ogilvie, G. (2008). Trends in sexual health and risk behaviours among adolescent students in British Columbia. The Canadian Journal of Human Sexuality, 17, 1-13.

Sakiz, G., Pape, S. J., \& Hoy, A. W. (2012). Does perceived teacher affective support matter for middle school students in mathematics classrooms?.Journal of School Psychology, 50(2), $235-255$.

San Antonio, D. M. (2006). Broadening the World of Early Adolescents. Educational Leadership, 63(7), 8-13.

Santrock, J. W. (2011). Adolescence (14th Ed.). New York: McGraw-Hill Companies.

Satorra, A., \& Bentler, P. M. (2001). A scaled difference chi-square test statistic for moment structure analysis. Psychometrika, 66(4), 507-514.

Schwartz, S. J., Côté, J. E., \& Arnett, J. J. (2005). Identity and agency in emerging adulthood: Two developmental routes in the individualization process. Youth and Society, 37, 201229. 
Schwartz, S. J., Beyers, W., Luyckx, K., Soenens, B., Zamboanga, B. L., Forthun, L. F., ... Waterman, A. S. (2011). Examining the light and dark sides of emerging adults' identity: a study of identity status differences in positive and negative psychosocial functioning. Journal of Youth and Adolescence, 40(7), 839-59.

Shaffer, D. (2009). Social and Personality Development. (M. Sordi \& P. Leeds, Eds.) (Sixth.). Belmont, CA: Wadsworth, Cengage Learning.

Shernoff, D. J., Csikszentmihalyi, M., Shneider, B., \& Shernoff, E. S. (2003). Student engagement in high school classrooms from the perspective of flow theory. School Psychology Quarterly, 18(2), 158.

Simona, L. (2009). Adolescents in different contexts: the exploration of identity through possible selves. Cognition, Brain, Behavior, XIII(3), 221-252.

Sinai, M., Kaplan, A., \& Flum, H. (2012). Promoting identity exploration within the school curriculum: A design-based study in a Junior High literature lesson in Israel. Contemporary Educational Psychology, 37(3), 195-205. doi:10.1016/j.cedpsych.2012.01.006

Sirin, S. R. (2005). Socioeconomic status and academic achievement: A meta-analytic review of research. Review of Educational Research, 75 (3), 417-453.

Skerrett, A. (2012). "We hatched in this class": Repositioning of identity in and beyond a reading classroom repositioning of identity. The High School Journal, 62-76.

Sobel, Michael E. (1986). Some new results on indirect effects and their standard errors in covariance structure. Sociological Methodology, 16, 159-186.

South, S. J., Baumer, E. P., \& Lutz, A. (2003). Interpreting community effects on youth educational attainment. Youth \& Society, 35(1), 3-36. 
Spear, L. P. (2000). The adolescent brain and age-related behavioral manifestations. Neuroscience \& Biobehavioral Reviews, 24(4), 417-463.

Spriggs A.L., Halpern, C.T. (2008). Timing of sexual debut and initiation of postsecondary education by early adulthood. Perspectives on Sexual and Reproductive Health, 40(3), $152-161$.

Srabstein, J., Piazza, T. (2008). Public health, safety and educational risks associated with bullying behaviors in American adolescents. International Journal of Adolescent Medicine and Health, 20(2), 223-233.

Standage, M., Duda, J.L., \& Ntoumanis, N. (2003). A model of contextual motivation in physical education: Using constructs from self-determination and achievement goal theories to predict physical activity intentions. Journal of Educational Psychology,95(1), 97-110.

Steinberg, L. (2014). The Age of Opportunity: Lessons from the New Science of Adolescence. New York, NY: Houghton Mifflin Harcourt Publishing Company.

Steinberg, L. (2008). Adolescence. (E. Barrosse, Ed.) (8th ed.). New York, NY: McGraw Hill Higher Education.

Steinberg, L. (1996). Beyond the classroom: Why school reform has failed and what parents need to do. New York: Touchstone.

Steinberg, L., \& Morris, A. S. (2001). Adolescent development. Annual Review of Psychology, 52, 83-110.

Stewart, E.B. (2008). School structural characteristics, student effort, peer associations, and parental involvement: The influence of school- and individual-level factors on academic achievement. Education \& Urban Society, 40(2), 179-204.

Stolp, S., \& Smith, S. C. (1995). Transforming School Culture: Stories, Symbols, Values \& the 
Leader's Role. ERIC Clearinghouse on Educational Management, 5207 University of Oregon, 1787 Agate Street, Eugene, OR 97403-5207.

Stornes, T., Bru, E., \& Idsoe, T. (2008). Classroom social structure and motivational climates: On the influence of teachers' involvement, teachers' autonomy support and regulation in relation to motivational climates in school classrooms. Scandinavian Journal of Educational Research, 52(3), 315-329.

Sullivan, H. S. (1953). The interpersonal theory of psychiatry. New York: Norton.

Tabachnick, B. G. and Fidell, L. S. 2001. Using multivariate statistics, , 4th ed., Needham Heights, MA: Allyn \& Bacon.

Takkakura, M., Wake, N., \& Kobayashi, M. (2010). The contextual effect of school satisfaction on health-risk behaviors in Japanese high school students. Journal of School Health, $80(11)$

Teachman, J. D. (1987). Family background, educational resources, and educational attainment. American Sociological Review, 548-557.

Tian, L., Chen, H., \& Huebner, E. S. (2014). The longitudinal relationships between basic psychological needs satisfaction at school and school-related subjective well-being in adolescents. Social Indicators Research, 119(1), 353-372.

Titman, W. (1994). Special Places; Special People: The Hidden Curriculum of School Grounds. Green Brick Road, 429 Danforth Ave., Ste.\# 408, Toronto, Ontario, Canada M4K 1P1.

Trenz, R. C., Harrell, P., Scherer, M., Mancha, B. E., \& Latimer, W. W. (2012). A model of school problems, academic failure, alcohol initiation, and the relationship to adult heroin injection. Substance Use \& Misuse, 47, 1159-1171. doi:10.3109/10826084.2012.686142

U.S. Census Bureau (2014). Geography; urban and rural classifications by state for 2010 . 
Retrieved from: http://www.census.gov/geo/reference/ua/ualists_layout.html

U.S. Department of Education, National Center for Education Statistics. (2013). The Condition of Education 2013 (NCES 2013-037), Status Dropout Rates. Retrieved from: https://nces.ed.gov/programs/coe/indicator_coj.asp

Vallerand, R. J., Fortier, M. S., \& Guay, F. (1997). Self-determination and persistence in a reallife setting: toward a motivational model of high school dropout. Journal of Personality and Social psychology, 72(5), 1161.

Van Ryzin, M. J., Gravely, A. A., \& Roseth, C. J. (2009). Autonomy, belongingness, and engagement in school as contributors to adolescent psychological well-being. Journal of youth and adolescence, 38(1), 1-12.

Wallis, C., \& Park, A. (2004). What Makes Teens Tick. Time, 56-65.

Wang, M. T., Eccles, J. S., \& Kenny, S. (2013). Not lack of ability but more choice: Individual and gender differences in STEM career choice. Psychological Science. 24, 770-775.

Waterman, A. S. (1999). Identity, the identity statuses, and identity status development: A contemporary statement. Developmental Review, 19, 591-621.

Williams, D. (2011).Racial/ethnic variations in women's health: The Social Embeddedness of health. American Journal of Public Health, 92(4), 588-597.

Wright, R., John, L., Ellenbrogen, S., Offord, D., Duku, E., \& Rowe, W. (2006). Effect of a Structured Arts Program on the Psychosocial Functioning of Youth From Low-Income Communities: Findings From a Canadian Longitudinal Study. The Journal of Early Adolescence, 26(2), 186-205. 
Yoder, A. E. (2000). Barriers to ego identity status formation: a contextual qualification of Marcia's identity status paradigm. Journal of adolescence, 23(1), 95-106. doi:10.1006/jado.1999.0298

Zins, J. E., Bloodworth, M. R., Weissberg, R. P., \& Walberg, H. J. (2004). The Scientific Base Linking Social and Emotional Learning to School Success. Journal of Educational and Psychological Consultation, 17(2 \& 3), 191-210.

Zullig, K. J., Collins, R., Ghani, N., Patton, J. M., Scott Huebner, E., \& Ajamie, J. (2014). Psychometric support of the school climate measure in a large, diverse sample of adolescents: a replication and extension. Journal of school health, 84(2), 82-90.

Zullig, K.J., Koopman, T.M., Patton, J.M., \& Ubbes, V.A. (2010). School climate: Historical review, instrument development, and school assessment. Journal of Psychoeducational Assessment, 28 (2), 139-152.

Zullig, K. J., \& Patton, J. O. (2011). Relationships among school climate domains and school satisfaction. Psychology in the Schools, 48(2), 133-146. 


\section{Appendix A: Figures to support the present study}

Figure A1. Bronfenbrenner's Ecological Development Model

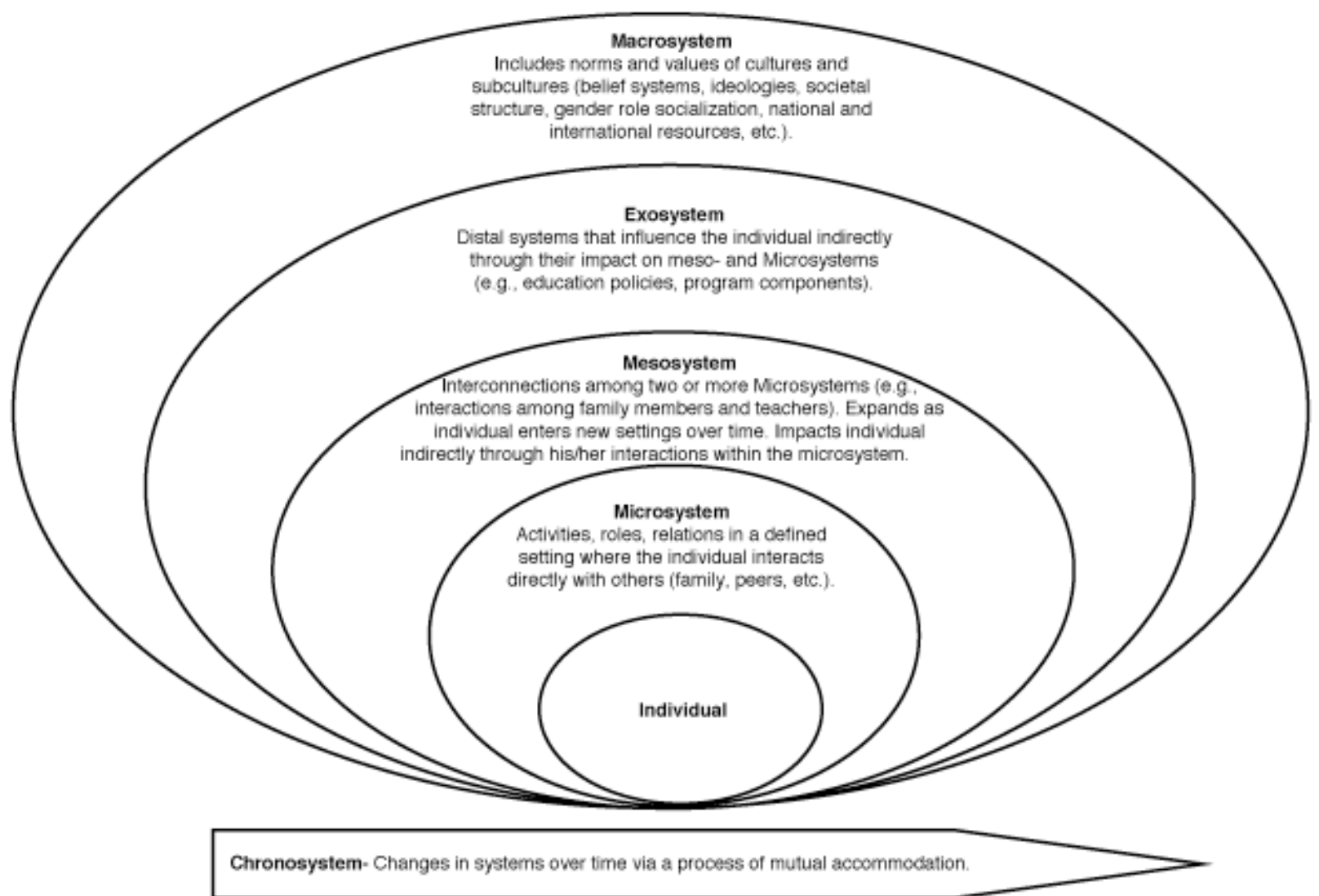

(Research and Training Center on Community Living, Institute on Community Integration, College of Education and Human Development, University of Minnesota, 2011). 
Figure A2. Diagram of the Mediation Model

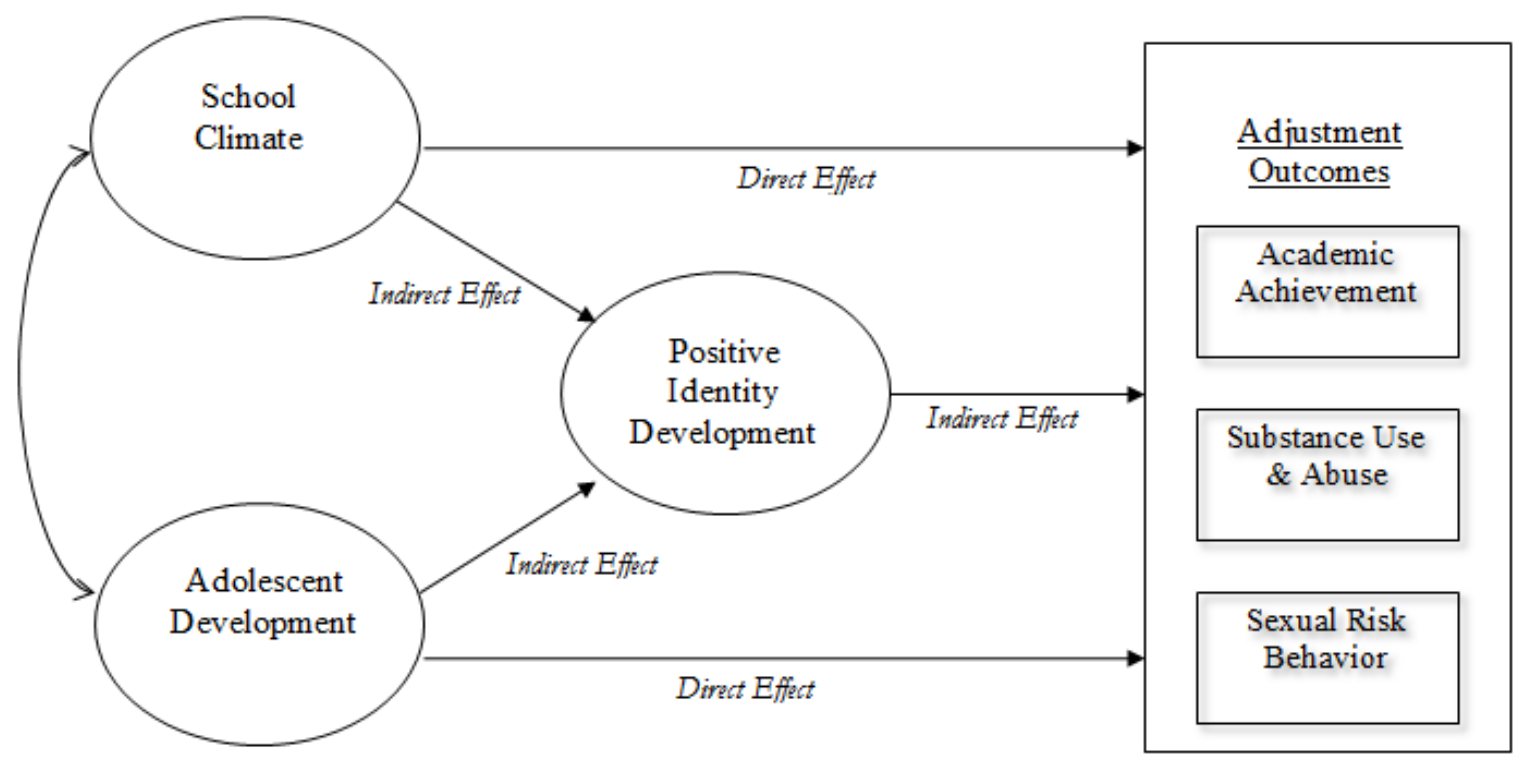




\section{Appendix B: Assent and consent letters and IRB Approval}

Figure B1. Participant Assent Letter.

\section{ICE Collaborative}

Dear Participant,

This is a request for you to take part in a research project that will identify the types of activities students may be doing that may help or hurt their future success. The results of this study will help adults create a supportive and safe environment for kids in the community.

This project is being conducted by Dr. Alfgeir L. Kristjansson, PhD., in the Department of Social and Behavioral Sciences in the School of Public Health at West Virginia University.

Completing this survey is voluntary. Whether or not you answer the questions will not affect you in any negative way. If you are not comfortable answering a question, just leave it blank. You may stop taking this survey at any time.

Please know that the answers you give to these questions are completely anonymous. No one will ever know how you answer these questions, so please be truthful. We also promise to keep your participation in this study confidential as well. This survey is the first in annual surveys that will be conducted 1-2 per year during the next 5 years.

We hope that you will participate in this research project, as it could help us improve the student experience at school in the future. Thank you very much for your time. If you have any questions about this letter or the research project, please feel free to contact Dr. Alfgeir L. Kristjansson, Ph.D., West Virginia University School of Public Health, tel: (304) 293-3129, email address: alkristjansson@ @sc.wvu.edu or Dr. Michael J. Mann, PhD., West Virginia University School of Public Health, tel: (304) 293-3560, email address: mjmann@hsc.wvu.edu . If you have questions about your rights as a research subject, you may contact the West Virginia University Office of Research Integrity and Compliance at (304) 293-7073.

Thank you for your time and help with this project. 
Figure B2. IRB Approval Letter.

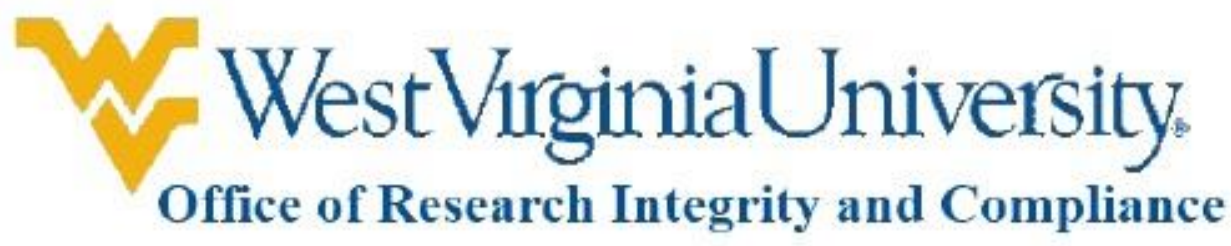

To

From

Approval Period Last Approval Date

Subject

Protocol Number

Title

\section{Approval Letter Amendment}

Alfgeir Kristjansson

WVU Office of Research Integrity and Compliance

08/08/2014 Expiration Date 08/11/2015

$08 / 21 / 2014$

Amendment to Approved Protocol

1406345394A001

The Integrated Community Engagement (ICE) Collaborative

The West Virginia University Institutional Review Board (IRB) has reviewed and approved the above referenced amendment. The amendment wording is as follows:

The Office of Research Integrity and Compliance is here to provide assistance to you from the initial submission of an IRB protocol to its approval and all subsequent activity. Please feel free to contact us by phone at 304.293.7073 with any question you may have. Thank you.

WVU Office of Research Integrity and Compliance

Date: $08 / 21 / 2014$

Signed:

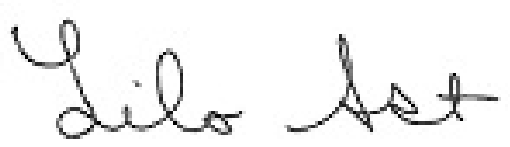

\section{Lilo Ast}

\section{Senior Program Coordinator}

Once you begin your human subject research, the following regulations apply:

1. Unanticipated or serious adverse events/side effects encountered in this research study must be reported to the IRB within five (5) days via the Notify IRB action.

2. Any modifications to the study protocol or informed consent form must be reviewed and approved by the IRB prior to implementation via submission of an amendment.

3. You may not use a modified informed consent form until it has been approved and validated by the IRB. 


\section{Figure B3. Parental Passive Consent Letter.}

\section{West WirginiaUniversity SCHOOL OF PUBLIO HEALTH}

Dear Parents and Caregivers,

Your child has been selected to participate in a research study conducted by Dr. Michael Mann, $\mathrm{PhD}$. and Dr. Alfgeir Kristjansson, $\mathrm{PhD}$. at the West Virginia University School of Public Health. The title of the project is The Integrated Community Engagement (ICE) Collaborative. Please read this form for information about the survey, and for instructions on how to withdraw your child. If you do not want your child to complete the survey, please notify either Dr. Alfgeir L. Kristjansson, tel: (304) 293 3129, email address: alkristjansson@hsc.wvu.edu or Dr. Michael J. Mann, tel: 304293 3560, email address: mimann@hsc.wvu.edu, either by telephone or by email and your child will not be asked to participate in the survey. If you wish to have your consent for your child's participation documented please sign at the back of the letter. This is optional and not required for participation.

The purpose of this study is to identify the types of activities students are doing that may help or hurt their personal success and the success of the community. The results of this study will help adult's create a supportive and safe environment where kids can do well. In order to complete this study, we will give your child a survey. Most of the questions on the survey are pretty harmless. They are about things like getting along with teachers, following rules, and homework. However, sometimes students have a hard time being successful in school because of things that are sensitive and hard to talk about. As a result, some of our questions are somewhat sensitive, too. They include things like whether or not students have had sex, smoke cigarettes, drink alcohol, or do other drugs. Depending on grade, the survey takes between 25-45 minutes to complete. Participation in the survey is voluntary, participants can withdraw from the study at any time and there will be no penalties for refusing to participate. All responses are anonymous. This survey is the first in annual surveys that will be conducted once to twice per year during the next 5 years.

Although we don't intend to cause any stress, we know it's possible and do several things to help your child be safe and feel comfortable. For instance, we ask as few sensitive questions as possible. We let everyone know they can skip any questions they do not want to answer or quit taking the survey whenever they want. We also let them know that if they choose to skip a question or quit, that they will not get in any trouble at all. We let them know that their responses will be anonymous and their participation confidential, and that their name will never appear on any survey they complete. Finally, we make sure school counselors are available in case anyone has something they want to talk about after the survey.

If you choose to let your child be a part of this study, all of their information will be collected anonymously. This means that because of the way we are using computers and anonymous questionnaires to ask questions, no one will ever know how your child answers any question in our survey, including us! The same thing is true when we are given information from student records. We never see any student names, just numbers. And as a result, any information from student records will also be kept anonymous. Further, although the research team will know your child was in the study, well will keep their participation confidential by not sharing that information with anyone. 


\section{Appendix C: Measures used in the current study}

\section{Figure C1. The School Climate Measure.}

Factor 1: Positive Student-Teacher Relationships (11.7\%)

Teachers understand my problems

Teachers and staff seem to take a real interest in my future

Teachers are available when I need to talk with them

It is easy to talk with teachers

Students get along well with teachers

Teachers at my school help us children with our problems

My teachers care about me

My teacher makes me feel good about myself

Factor 2: Order and Discipline (7.9\%)

Classroom rules are applied equally

Problems in this school are solved by students and staff

The rules of the school are fair

School rules are enforced consistently and fairly

My teachers make it clear to me when I have misbehaved in class

Discipline is fair

Factor 3: Positive Student Engagement (7.5\%)

Students have same opportunity in class to speak, and be listened to, in class (new)

Students can express feelings and thoughts about school work and life (new)

Students "different" in any way are treated with respect (new)

Nobody in my school is excluded from being successful (new)

Females and males treated as equals at school (new)

I can participate in a lot of interesting activities at school (new)

Factor 4: School Physical Environment (6.5\%)

The school grounds are kept clean

My school is neat and clean

My school buildings are generally pleasant and well maintained

My school is usually clean and tidy

Factor 5: Academic Support (5.6\%)

I usually understand my homework assignments

Teachers make it clear what work needs to be done to get the grade I want

I believe that teachers expect all students to leam

I feel that I can do well in this school

Factor 6: Parental Involvement (5.5\%)

My parents talk with teachers about what is happening at home (new)

My parents are involved in school activities (new)

My parents are involved in discussions about what is taught at school (new)

Factor 7: School Connectedness (5.2\%)

My schoolwork is exciting

Students can make suggestions on courses that are offered

This school make student enthusiastic about learning

Students are frequently rewarded or praised by faculty and staff for following school rules

Factor 8: Perceived Exclusion/ Privilege (5.1\%)

At my school, the same person always gets to help the teacher

At my school, the same students get chosen every time to take part in after-school or special activities

The same students always get to use things, like a computer, a ball or piano, when we interact 
Factor 9: School Social Environment (4.2\%)

I am happy with the kinds of students who go to my school

I am happy, in general, with the other students who go to my school

Factor 10: Academic Satisfaction (4.1\%)

I am happy about the number of tests I have

I am happy about the amount of homework I have 
Figure C2. Basic Psychological Needs Satisfaction.

\title{
Basic Need Satisfaction in General
}

\author{
Feelings I Have
}

Please read each of the following items carefully, thinking about how it relates to your life, and then indicate how true it is for you. Use the following scale to respond:

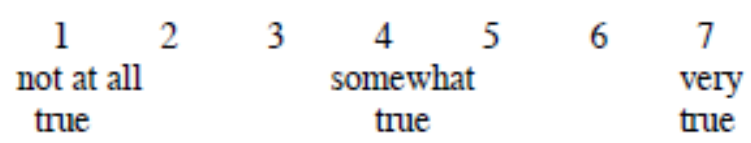

1. I feel like I am free to decide for myself how to live my life.

2. I really like the people I interact with.

3. Often, I do not feel very competent.

4. I feel pressured in my life.

5. People I know tell me I am good at what I do.

6. I get along with people I come into contact with.

7. I pretty much keep to myself and don't have a lot of social contacts.

8. I generally feel free to express my ideas and opinions.

9. I consider the people I regularly interact with to be my friends.

10. I have been able to learn interesting new skills recently.

11. In my daily life, I frequently have to do what I am told.

12. People in my life care about me.

13. Most days I feel a sense of accomplishment from what I do.

14. People I interact with on a daily basis tend to take my feelings into consideration.

15. In my life I do not get much of a chance to show how capable I am.

16. There are not many people that I am close to.

17. I feel like I can pretty much be myself in my daily situations.

18. The people I interact with regularly do not seem to like me much.

19. I often do not feel very capable.

20. There is not much opportunity for me to decide for myself how to do things in my daily life.

21. People are generally pretty friendly towards me. 
Figure C3. The Dimensions of Identity Development.

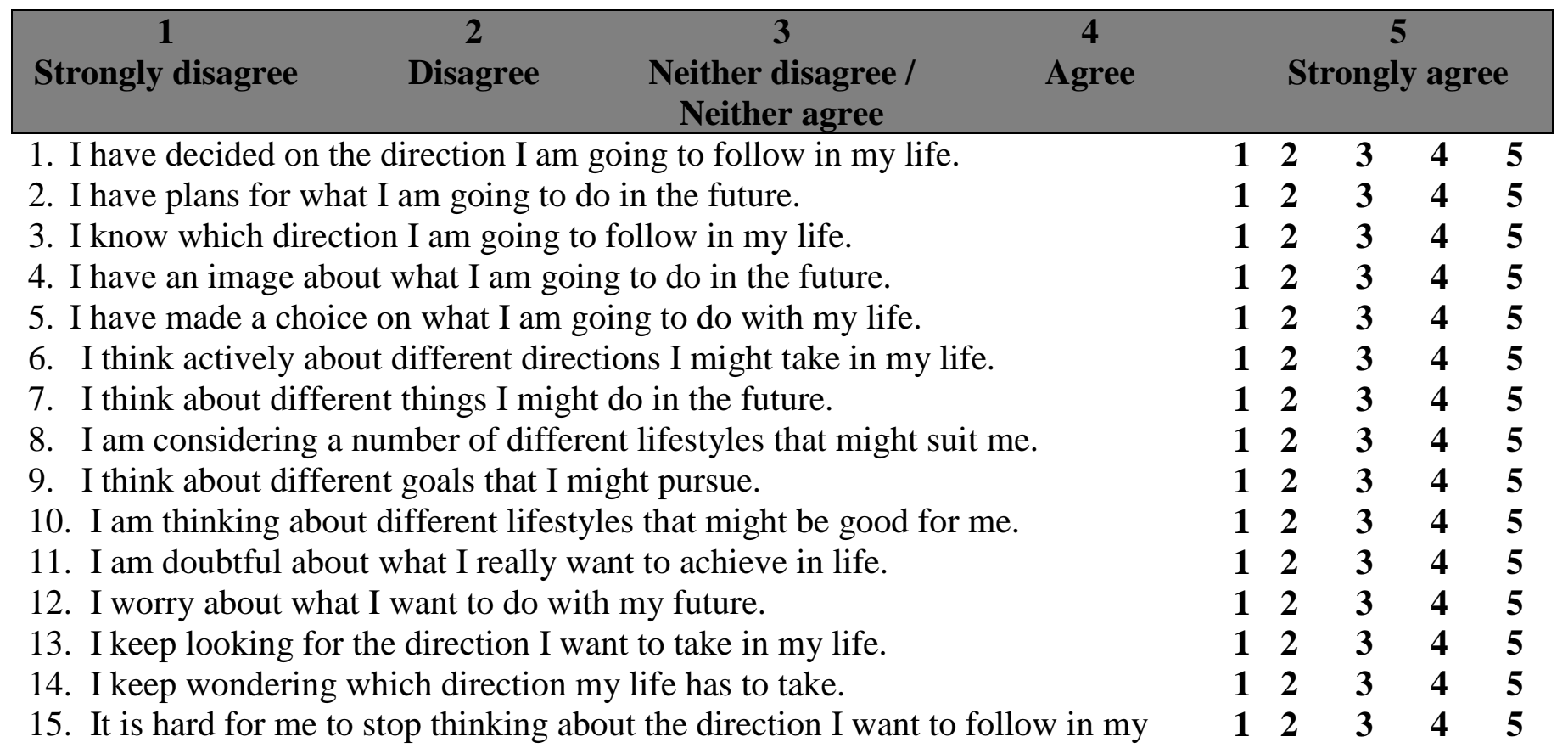
life.

16. My plans for the future match with my true interests and values.

17. My future plans give me self-confidence.

18. Because of my future plans, I feel certain about myself.

19. I sense that the direction I want to take in my life will really suit me.

20. I am sure that my plans for the future are the right ones for me.

21. I think about the future plans I already made.

22. I talk with other people about my plans for the future.

23. I think about whether the aims I already have for life really suit me.

24. I try to find out what other people think about the specific direction I decided to take in my life.

25. I think about whether my future plans match with what I really want. All items are scored on a five-point Likert type rating scale with 1 (Strongly disagree) to 5 (Strongly Agree).

\section{DIDS subscales}

Items $1-5$ : Commitment making Items 6-10: Exploration in breadth Items 11 - 15: Ruminative exploration Items 16 - 20: Identification with commitment Items $21-25$ : Exploration in depth 
Figure C4. ICE project Survey

Please write your 9-digit WVEIS number (Your usual log-in number):

Please respond to the questions on the following pages by marking with an " $X$ " in the appropriate bubble or box:

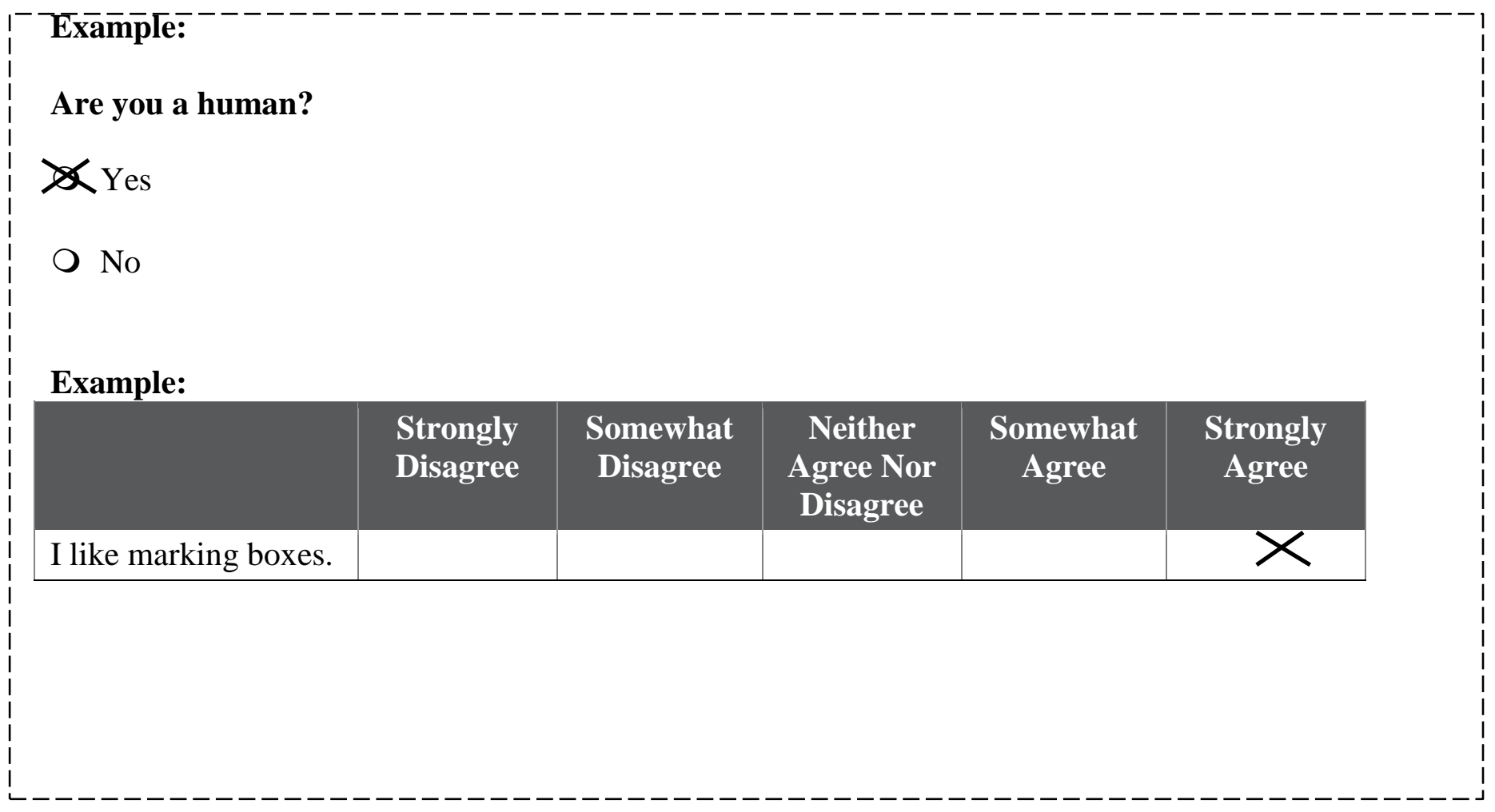

Please complete the following survey. Thank you! 
Are you a boy or a girl?

O Boy

O Girl

What is your year of birth?

○ 1995

○ 1996

○ 1997

○ 1998

○ 1999

○ 2000

○ 2001

○ 2002

○ 2003

○ 2004

○ 2005

○ 2006

○ 2007

○ 2008

What is your current grade in school?

5th Grade

O 6th Grade

7th Grade

O 8th Grade

9th Grade

O 10th Grade

O 11th Grade

O 12th Grade

How do you describe yourself? (Select all that apply)

$\square$ American Indian or Native American

$\square$ Asian

$\square$ Black or African American- not Hispanic

$\square$ Hispanic or Latino

- Native Hawaiian or Other Pacific Islander

$\square$ White

口 Other: 
Which of the following persons live in your home? (Choose as many options as apply).

$\square$ Mother

$\square$ Father

$\square$ Older sister (one or more)

$\square$ Older brother (one or more)

$\square$ Younger sister (one or more)

$\square$ Younger brother (one or more)

$\square$ Stepmother

S Stepfather

$\square$ Foster- mother

$\square$ Foster- father

Parent's girlfriend, boyfriend, or partner

$\square$ Grandmother

$\square$ Grandfather

$\square$ Aunt

$\square$ Uncle

$\square$ A friend's parent or parents

$\square$ Friends

I live on my own

Other:

What is the highest level of schooling your mother has completed? (If you are mostly brought up by a step-mother or foster-mother you can answer for her)

O I don't know/Doesn't apply

Graduated with a Master's, Doctorate, or Professional Degree

O Graduated from a university or 4-year college

Started university or 4-year college but has not finished

Graduated from junior college or trade school

Started junior college or trade school but has not finished

Graduated from high school

Started high school but has not finished

O Elementary or middle school or less

What is the highest level of schooling your father has completed? (If you are mostly brought up by a step-father or foster-father you can answer for him)

I don't know/Doesn't apply

Graduated with a Master's, Doctorate, or Professional Degree

Graduated from a university or 4-year college

Started university or 4-year college but has not finished

Graduated from junior college or trade school

Started junior college or trade school but has not finished 
Graduated from high school

Started high school but has not finished

O Elementary or middle school or less

During the last 12 months have you:

\begin{tabular}{|l|l|l|}
\hline $\begin{array}{l}\text { Moved to a different neighborhood or } \\
\text { community? }\end{array}$ & Yes & No \\
\hline Changed schools? & & \\
\hline
\end{tabular}

Have you, during the last 5 years:

\begin{tabular}{|l|l|l|l|l|l|l|} 
& Never & Once & Twice & $\begin{array}{l}\text { Three } \\
\text { times }\end{array}$ & $\begin{array}{c}\text { Four } \\
\text { times }\end{array}$ & $\begin{array}{c}\text { Five or } \\
\text { more }\end{array}$ \\
\hline $\begin{array}{l}\text { Moved to a different } \\
\text { community or neighborhood? }\end{array}$ & & & & & & \\
\hline Changed schools? & & & & & & \\
\hline
\end{tabular}

How well do the following statements apply to you?

\begin{tabular}{|l|l|l|l|l|}
\hline $\begin{array}{l}\text { Sometimes it is important/necessary to } \\
\text { smoke cigarettes in order to be included } \\
\text { in my peer group }\end{array}$ & $\begin{array}{c}\text { Strongly } \\
\text { Agree } \\
\text { Somewhat }\end{array}$ & $\begin{array}{c}\text { Agree } \\
\text { Disagree }\end{array}$ & $\begin{array}{c}\text { Strongly } \\
\text { Disagree }\end{array}$ \\
\hline $\begin{array}{l}\text { Sometimes it is important to drink } \\
\text { alcohol in order to be included in my } \\
\text { peer group. }\end{array}$ & & & \\
\hline $\begin{array}{l}\text { Sometimes it is important to smoke } \\
\text { marijuana in order to be included in my } \\
\text { peer group }\end{array}$ & & & \\
\hline $\begin{array}{l}\text { Sometimes it is important to get bad } \\
\text { grades in school in order to be included } \\
\text { in my peer group. }\end{array}$ & & & \\
\hline $\begin{array}{l}\text { Sometimes it is important to skip or cut } \\
\text { classes in order to be included in my } \\
\text { peer group. }\end{array}$ & & & & \\
\hline $\begin{array}{l}\text { Sometimes it is important to talk a lot } \\
\text { about sex in order to be included in my } \\
\text { peer group. }\end{array}$ & & & & \\
\hline $\begin{array}{l}\text { Sometimes it is important to make out } \\
\text { with a lot of people in order to be }\end{array}$ & & & & \\
\hline
\end{tabular}




\begin{tabular}{|c|c|c|c|c|c|}
\hline \multicolumn{6}{|c|}{ included in my peer group. } \\
\hline \multicolumn{6}{|c|}{$\begin{array}{l}\text { Sometimes it is important to engage in } \\
\text { some form of sex (sexual touching, oral, } \\
\text { intercourse) in order to be included in } \\
\text { my peer group. }\end{array}$} \\
\hline \multicolumn{6}{|c|}{ What do you consider important to do to gain respect from your friends? } \\
\hline & $\begin{array}{l}\text { Increases } \\
\text { respect a } \\
\text { lot }\end{array}$ & $\begin{array}{l}\text { Increases } \\
\text { respect } \\
\text { somewhat }\end{array}$ & $\begin{array}{c}\text { Has no } \\
\text { effect }\end{array}$ & $\begin{array}{c}\text { Decreases } \\
\text { respect } \\
\text { somewhat }\end{array}$ & $\begin{array}{l}\text { Decreases } \\
\text { respect a } \\
\text { lot }\end{array}$ \\
\hline \multicolumn{6}{|l|}{ To do well in school } \\
\hline \multicolumn{6}{|l|}{ To do well in sports } \\
\hline \multicolumn{6}{|l|}{ To drink alcohol } \\
\hline \multicolumn{6}{|l|}{ To smoke cigarettes } \\
\hline \multicolumn{6}{|l|}{ To smoke marijuana } \\
\hline \multicolumn{6}{|l|}{ To look good } \\
\hline \multicolumn{6}{|c|}{$\begin{array}{l}\text { To be against the rules of } \\
\text { adults }\end{array}$} \\
\hline \multicolumn{6}{|l|}{ To steal from shops } \\
\hline \multicolumn{6}{|c|}{ To know a lot about sex } \\
\hline \multicolumn{6}{|c|}{$\begin{array}{l}\text { To make out with lots of } \\
\text { people }\end{array}$} \\
\hline To have lots of sex & & & & & \\
\hline
\end{tabular}

How many of your friends do you think...

\begin{tabular}{|l|l|l|l|l|l|}
\hline \multicolumn{1}{|c|}{ None } & A few & Some & Most & All \\
\hline $\begin{array}{l}\text { Drink alcohol beverages } \\
\text { (liquor, beer, wine)? }\end{array}$ & & & & \\
\hline $\begin{array}{l}\text { Get drunk at least once a } \\
\text { week? }\end{array}$ & & & & & \\
\hline Smoke marijuana? & & & & & \\
\hline $\begin{array}{l}\text { Have sex (sexual } \\
\text { touching, oral, } \\
\text { intercourse)? }\end{array}$ & & & & \\
\hline $\begin{array}{l}\text { Have been pregnant or } \\
\text { gotten someone } \\
\text { pregnant? }\end{array}$ & & & & & \\
\hline Get bad grades in school? & & & & & \\
\hline
\end{tabular}




\begin{tabular}{|c|c|c|c|c|c|}
\hline Skip classes or school? & & & & & \\
\hline Get in trouble at school? & & & & & \\
\hline How well do the followi & ply to yo & & & & \\
\hline & $\begin{array}{l}\text { Almost } \\
\text { Never }\end{array}$ & Seldom & Sometimes & Often & $\begin{array}{l}\text { Almost } \\
\text { Always }\end{array}$ \\
\hline $\begin{array}{l}\text { I spend time with my } \\
\text { parents/caregiver outside } \\
\text { school hours on working } \\
\text { days. }\end{array}$ & & & & & \\
\hline $\begin{array}{l}\text { I spend time with my } \\
\text { parents/caregiver during } \\
\text { the weekends. }\end{array}$ & & & & & \\
\hline
\end{tabular}

Do your parents/caregivers know where you spend Saturday evenings?

O Almost Always

O Often

O Sometimes

O Seldom

O Almost Never

How well do the following apply to you?

\begin{tabular}{|l|l|l|l|l|}
\hline $\begin{array}{l}\text { My parents/caregivers set } \\
\text { definite rules about what I } \\
\text { can do at home. }\end{array}$ & $\begin{array}{c}\text { Applies very } \\
\text { well to me }\end{array}$ & $\begin{array}{c}\text { Applies pretty } \\
\text { well to me }\end{array}$ & $\begin{array}{c}\text { Applies pretty } \\
\text { poorly to me }\end{array}$ & $\begin{array}{c}\text { Applies very } \\
\text { poorly to me }\end{array}$ \\
\hline $\begin{array}{l}\text { My parents/caregivers set } \\
\text { definite rules about what I } \\
\text { can do outside the home. }\end{array}$ & & & & \\
\hline $\begin{array}{l}\text { My parents/caregivers set } \\
\text { definite rules about when I } \\
\text { should be home in the } \\
\text { evening. }\end{array}$ & & & & \\
\hline $\begin{array}{l}\text { My parents/caregivers } \\
\text { know whom I am with in } \\
\text { the evenings. }\end{array}$ & & & & \\
\hline $\begin{array}{l}\text { My parents/caregivers } \\
\text { know where I am in the } \\
\text { evenings. }\end{array}$ & & & & \\
\hline $\begin{array}{l}\text { My parents/caregivers } \\
\text { know my friends. }\end{array}$ & & & & \\
\hline My parents/caregivers & & & & \\
\hline
\end{tabular}




\begin{tabular}{|l|l|l|l|}
\hline $\begin{array}{l}\text { know the parents of my } \\
\text { friends. }\end{array}$ & & & \\
\hline $\begin{array}{l}\text { My parents/caregivers } \\
\text { often talk to the parents of } \\
\text { my friends. }\end{array}$ & & & \\
\hline
\end{tabular}


Which of the following people living in your home smoke tobacco on a daily basis?

\begin{tabular}{|l|l|l|l|}
\multicolumn{2}{|c|}{ Yes } & \multicolumn{1}{c|}{ No } & $\begin{array}{c}\text { Doesn't live in my } \\
\text { home }\end{array}$ \\
\hline $\begin{array}{l}\text { Father (or Stepfather or } \\
\text { Foster-father) }\end{array}$ & & & \\
\hline $\begin{array}{l}\text { Mother (or Stepmother or } \\
\text { Foster-mother) }\end{array}$ & & & \\
\hline Grandmother & & & \\
\hline Grandfather & & & \\
\hline Sister & & & \\
\hline Brother & & & \\
\hline
\end{tabular}

Which of the following people living in your home often drink alcohol until they are drunk?

\begin{tabular}{|l|l|l|l|}
\hline \multicolumn{1}{|c|}{ Yes } & \multicolumn{1}{c|}{ No } & $\begin{array}{c}\text { Doesn't live in my } \\
\text { home }\end{array}$ \\
\hline $\begin{array}{l}\text { Father (or Stepfather or } \\
\text { Foster-father) }\end{array}$ & & & \\
\hline $\begin{array}{l}\text { Mother (or Stepmother or } \\
\text { Foster-mother) }\end{array}$ & & & \\
\hline Grandmother & & & \\
\hline Grandfather & & & \\
\hline Sister & & & \\
\hline Brother & & & \\
\hline
\end{tabular}

How do you think your parents/caregivers would react if they found out you did any of the following?

\begin{tabular}{|l|l|l|l|l|}
\hline & $\begin{array}{c}\text { Totally } \\
\text { Against }\end{array}$ & $\begin{array}{c}\text { Very Much } \\
\text { Against }\end{array}$ & $\begin{array}{c}\text { Pretty } \\
\text { Against }\end{array}$ & $\begin{array}{c}\text { They } \\
\text { would not } \\
\text { care }\end{array}$ \\
\hline Smoked cigarettes & & & & \\
\hline Got drunk & & & & \\
\hline Smoked marijuana & & & & \\
\hline Got bad grades in school & & & & \\
\hline $\begin{array}{l}\text { Got suspended or expelled from } \\
\text { school }\end{array}$ & & & & \\
\hline Skipped class or day of school & & & & \\
\hline
\end{tabular}




\begin{tabular}{|c|c|c|c|c|c|}
\hline \multicolumn{6}{|l|}{ Had sex of any kind } \\
\hline \multicolumn{6}{|c|}{ Had unprotected sexual intercourse } \\
\hline \multicolumn{6}{|l|}{$\begin{array}{l}\text { If you got pregnant or you got } \\
\text { someone else pregnant }\end{array}$} \\
\hline \multicolumn{6}{|c|}{ The next group of questions asks about your relationships with your teachers. } \\
\hline & $\begin{array}{l}\text { Strongly } \\
\text { Disagree }\end{array}$ & Disagree & $\begin{array}{l}\text { Neither } \\
\text { Agree nor } \\
\text { Disagree }\end{array}$ & Agree & $\begin{array}{l}\text { Strongly } \\
\text { Agree }\end{array}$ \\
\hline \multicolumn{6}{|l|}{$\begin{array}{l}\text { Teachers understand my } \\
\text { problems. }\end{array}$} \\
\hline \multicolumn{6}{|l|}{$\begin{array}{l}\text { Teachers and staff seem to take a } \\
\text { real interest in my future. }\end{array}$} \\
\hline \multicolumn{6}{|l|}{$\begin{array}{l}\text { Teachers are available when I } \\
\text { need to talk to them. }\end{array}$} \\
\hline \multicolumn{6}{|l|}{ It is easy to talk with teachers. } \\
\hline \multicolumn{6}{|l|}{$\begin{array}{l}\text { Students get along well with } \\
\text { teachers. }\end{array}$} \\
\hline \multicolumn{6}{|l|}{$\begin{array}{l}\text { Teachers at my school help us } \\
\text { children with our problems. }\end{array}$} \\
\hline \multicolumn{6}{|l|}{ My teachers care about me. } \\
\hline $\begin{array}{l}\text { My teacher makes me feel good } \\
\text { about myself. }\end{array}$ & & & & & \\
\hline
\end{tabular}

The next group of questions asks about your feelings of order, safety, and discipline in your school.

\begin{tabular}{|l|l|l|l|l|l|}
\hline & $\begin{array}{c}\text { Strongly } \\
\text { Disagree }\end{array}$ & Disagree & $\begin{array}{c}\text { Neither } \\
\text { Agree nor } \\
\text { Disagree }\end{array}$ & Agree & $\begin{array}{c}\text { Strongly } \\
\text { Agree }\end{array}$ \\
\hline $\begin{array}{l}\text { Classroom rules are applied } \\
\text { equally. }\end{array}$ & & & & \\
\hline $\begin{array}{l}\text { Problems in this school are solved } \\
\text { by students and staff. }\end{array}$ & & & & & \\
\hline The rules of the school are fair. & & & & & \\
\hline $\begin{array}{l}\text { School rules are enforced } \\
\text { consistently and fairly. }\end{array}$ & & & & & \\
\hline $\begin{array}{l}\text { My teachers make it clear to me } \\
\text { when I have misbehaved in class. }\end{array}$ & & & & & \\
\hline Discipline is fair. & & & & & \\
\hline
\end{tabular}


The next group of questions asks about your ability to participate in school activities.

\begin{tabular}{|l|l|l|l|l|l|}
\hline & $\begin{array}{c}\text { Strongly } \\
\text { Disagree }\end{array}$ & Disagree & $\begin{array}{c}\text { Neither } \\
\text { Agree nor } \\
\text { Disagree }\end{array}$ & Agree & $\begin{array}{c}\text { Strongly } \\
\text { Agree }\end{array}$ \\
\hline $\begin{array}{l}\text { Students have the same } \\
\text { opportunity in class to speak, and } \\
\text { be listened to. }\end{array}$ & & & & & \\
\hline $\begin{array}{l}\text { Students can express feelings and } \\
\text { thoughts about school, work, and } \\
\text { life. }\end{array}$ & & & & & \\
\hline $\begin{array}{l}\text { Students "different" in any way } \\
\text { are treated with respect. }\end{array}$ & & & & \\
\hline $\begin{array}{l}\text { Nobody in my school is excluded } \\
\text { from being successful. }\end{array}$ & & & & & \\
\hline $\begin{array}{l}\text { Females and males are treated as } \\
\text { equals at school. }\end{array}$ & & & & & \\
\hline $\begin{array}{l}\text { I can participate in a lot of } \\
\text { interesting activities in school. }\end{array}$ & & & & & \\
\hline
\end{tabular}

The next group of questions asks about your feelings of your school's physical appearance.

\begin{tabular}{|l|l|l|l|l|l|}
\hline & $\begin{array}{c}\text { Strongly } \\
\text { Disagree }\end{array}$ & Disagree & $\begin{array}{c}\text { Neither } \\
\text { Agree nor } \\
\text { Disagree }\end{array}$ & Agree & $\begin{array}{c}\text { Strongly } \\
\text { Agree }\end{array}$ \\
\hline $\begin{array}{l}\text { The school grounds are kept } \\
\text { clean. }\end{array}$ & & & & \\
\hline My school is neat and clean. & & & & \\
\hline $\begin{array}{l}\text { My school buildings are generally } \\
\text { pleasant and well maintained. }\end{array}$ & & & & & \\
\hline $\begin{array}{l}\text { My school is usually clean and } \\
\text { tidy. }\end{array}$ & & & & & \\
\hline
\end{tabular}

The next group of questions asks about your feelings of academic support in your school.

\begin{tabular}{|l|l|l|l|l|l|} 
& $\begin{array}{c}\text { Strongly } \\
\text { Disagree }\end{array}$ & Disagree & $\begin{array}{c}\text { Neither } \\
\text { Agree nor } \\
\text { Disagree }\end{array}$ & Agree & $\begin{array}{c}\text { Strongly } \\
\text { Agree }\end{array}$ \\
\hline $\begin{array}{l}\text { I usually understand my homework } \\
\text { assignments. }\end{array}$ & & & & \\
\hline $\begin{array}{l}\text { Teachers make it clear what work } \\
\text { needs to be done to get the grade I }\end{array}$ & & & & \\
\hline
\end{tabular}




\begin{tabular}{|l|l|l|l|l|l|}
\hline want. & & & & & \\
\hline $\begin{array}{l}\text { I believe that teachers expect all } \\
\text { students to learn. }\end{array}$ & & & & & \\
\hline $\begin{array}{l}\text { I feel that I can do well in this } \\
\text { school. }\end{array}$ & & & & & \\
\hline
\end{tabular}

The next group of questions asks about your feelings about your parent or caregiver's involvement at school.

\begin{tabular}{|l|l|l|l|l|l|}
\hline & $\begin{array}{c}\text { Strongly } \\
\text { Disagree }\end{array}$ & Disagree & $\begin{array}{c}\text { Neither } \\
\text { Agree } \\
\text { nor } \\
\text { Disagree }\end{array}$ & Agree & $\begin{array}{c}\text { Strongly } \\
\text { Agree }\end{array}$ \\
\hline $\begin{array}{l}\text { My parents/caregivers talk with } \\
\text { teachers about what is happening } \\
\text { at home. }\end{array}$ & & & & \\
\hline $\begin{array}{l}\text { My parents/caregivers are } \\
\text { involved in school activities. }\end{array}$ & & & & \\
\hline $\begin{array}{l}\text { My parent/caregivers are involved } \\
\text { in discussions about what is } \\
\text { taught at school. }\end{array}$ & & & & \\
\hline
\end{tabular}

The next group of questions asks about your feelings of connectedness to your school.

\begin{tabular}{|l|l|l|l|l|l|}
\hline & $\begin{array}{c}\text { Strongly } \\
\text { Disagree }\end{array}$ & Disagree & $\begin{array}{c}\text { Neither } \\
\text { Agree } \\
\text { nor } \\
\text { Disagree }\end{array}$ & \multicolumn{1}{|c|}{$\begin{array}{c}\text { Agree } \\
\text { Agree }\end{array}$} & $\begin{array}{c}\text { Strongly } \\
\text { My schoolwork is exciting. }\end{array}$ \\
\hline $\begin{array}{l}\text { Students can make suggestions on } \\
\text { courses that are offered. }\end{array}$ & & & & & \\
\hline $\begin{array}{l}\text { This school makes students } \\
\text { enthusiastic about learning. }\end{array}$ & & & & & \\
\hline $\begin{array}{l}\text { Students are frequently rewarded } \\
\text { or praised by faculty and staff for } \\
\text { following school rules. }\end{array}$ & & & & & \\
\hline
\end{tabular}


The next group of questions asks about your ability to participate in school activities

\begin{tabular}{|l|l|l|l|l|l|}
\hline & $\begin{array}{c}\text { Strongly } \\
\text { Disagree }\end{array}$ & Disagree & $\begin{array}{c}\text { Neither } \\
\text { Agree } \\
\text { nor } \\
\text { Disagree }\end{array}$ & Agree & $\begin{array}{c}\text { Strongly } \\
\text { Agree }\end{array}$ \\
\hline $\begin{array}{l}\text { At my school, the same person } \\
\text { always gets to help the teacher. }\end{array}$ & & & & \\
\hline $\begin{array}{l}\text { At my school, the same students } \\
\text { get chosen every time to take part } \\
\text { in after-school or special } \\
\text { activities. }\end{array}$ & & & & \\
\hline $\begin{array}{l}\text { The same students always get to } \\
\text { use things, like a computer, a ball, } \\
\text { or piano, when we interact. }\end{array}$ & & & & \\
\hline
\end{tabular}

The next group of questions asks about your feelings of your school's social atmosphere.

\begin{tabular}{|l|l|l|l|l|} 
& $\begin{array}{c}\text { Strongl } \\
\text { Disagre } \\
\text { D }\end{array}$ & $\begin{array}{c}\text { Disagre } \\
\text { e }\end{array}$ & $\begin{array}{c}\text { Neither } \\
\text { Agree } \\
\text { nor } \\
\text { Disagre } \\
\text { e }\end{array}$ \\
\hline $\begin{array}{l}\text { I am happy with the kinds of students who } \\
\text { go to my school. }\end{array}$ & & & & $\begin{array}{c}\text { Strongl } \\
\text { y Agree }\end{array}$ \\
\hline $\begin{array}{l}\text { I am happy, in general, with the other } \\
\text { students who go to my school. }\end{array}$ & & & & \\
\hline
\end{tabular}

The next group of questions asks about your satisfaction with your schoolwork.

\begin{tabular}{|c|c|c|c|c|c|}
\hline & $\begin{array}{c}\text { Strongl } \\
\mathbf{y} \\
\text { Disagre } \\
\mathbf{e}\end{array}$ & $\begin{array}{l}\text { Disagre } \\
\mathbf{e}\end{array}$ & $\begin{array}{c}\text { Neither } \\
\text { Agree } \\
\text { nor } \\
\text { Disagre } \\
\text { e }\end{array}$ & Agree & $\begin{array}{l}\text { Strongl } \\
\text { y Agree }\end{array}$ \\
\hline $\begin{array}{l}\text { I am happy about the number of tests I } \\
\text { have. }\end{array}$ & & & & & \\
\hline $\begin{array}{l}\text { I am happy about the amount of } \\
\text { homework I have. }\end{array}$ & & & & & \\
\hline
\end{tabular}


During the last 7 days, how often did you do the following?

\begin{tabular}{|l|l|l|l|l|l|l|l|l|}
\hline & Never & Once & Twice & $\begin{array}{c}\text { Three } \\
\text { times }\end{array}$ & $\begin{array}{c}\text { Four } \\
\text { times }\end{array}$ & $\begin{array}{c}\text { Five } \\
\text { times }\end{array}$ & $\begin{array}{c}\text { Six } \\
\text { Times }\end{array}$ & $\begin{array}{c}\text { Seven } \\
\text { times }\end{array}$ \\
\hline $\begin{array}{l}\text { Stayed at home for a } \\
\text { whole evening. }\end{array}$ & & & & & & & & \\
\hline $\begin{array}{l}\text { Was outside after ten } \\
\text { o'clock in the evening. }\end{array}$ & & & & & & & & \\
\hline $\begin{array}{l}\text { Went outside and returned } \\
\text { after midnight. }\end{array}$ & & & & & & & & \\
\hline
\end{tabular}

How much do you agree or disagree with the following statements?

\begin{tabular}{|l|l|l|l|l|}
\hline $\begin{array}{l}\text { There is a great deal of social life } \\
\text { available in my community. }\end{array}$ & $\begin{array}{c}\text { Strongly } \\
\text { Disagree }\end{array}$ & Disagree & Agree & $\begin{array}{c}\text { Strongly } \\
\text { Agree }\end{array}$ \\
\hline It is good to live in my community. & & & & \\
\hline $\begin{array}{l}\text { In the future I would like to live in the } \\
\text { community that I live in now. }\end{array}$ & & & & \\
\hline
\end{tabular}

Do do you participate in any of the following out-of-school activities that are supervised by adults? 


\begin{tabular}{|c|c|c|c|c|c|c|c|c|c|}
\hline & $\begin{array}{l}\text { Almost } \\
\text { Never }\end{array}$ & $\begin{array}{l}\text { Less } \\
\text { than } \\
\text { once } \\
\text { per } \\
\text { week }\end{array}$ & $\begin{array}{l}\text { Once } \\
\text { per } \\
\text { week }\end{array}$ & $\begin{array}{c}2 \\
\text { times } \\
\text { per } \\
\text { week }\end{array}$ & $\begin{array}{c}3 \\
\text { times } \\
\text { per } \\
\text { week }\end{array}$ & $\begin{array}{c}4 \\
\text { times } \\
\text { per } \\
\text { week }\end{array}$ & $\begin{array}{c}5 \\
\text { times } \\
\text { per } \\
\text { week }\end{array}$ & $\begin{array}{c}6 \\
\text { times } \\
\text { per } \\
\text { week }\end{array}$ & $\begin{array}{c}7 \\
\text { times } \\
\text { per } \\
\text { week }\end{array}$ \\
\hline $\begin{array}{l}\text { Sports or sports } \\
\text { teams }\end{array}$ & & & & & & & & & \\
\hline Church groups & & & & & & & & & \\
\hline Girl or boy scout & & & & & & & & & \\
\hline $4 \mathrm{H}$ & & & & & & & & & \\
\hline $\begin{array}{l}\text { Student } \\
\text { government/ } \\
\text { leadership }\end{array}$ & & & & & & & & & \\
\hline $\begin{array}{l}\text { Other after schoo } \\
\text { clubs (ex: chess, } \\
\text { Spanish, etc.) }\end{array}$ & & & & & & & & & \\
\hline Music & & & & & & & & & \\
\hline Art & & & & & & & & & \\
\hline Drama & & & & & & & & & \\
\hline Dance & & & & & & & & & \\
\hline $\begin{array}{l}\text { Volunteering in } \\
\text { the community }\end{array}$ & & & & & & & & & \\
\hline
\end{tabular}

\section{How often do you do the following?}

\begin{tabular}{|c|c|c|c|c|c|}
\hline & $\begin{array}{l}\text { Almost } \\
\text { Never }\end{array}$ & $\begin{array}{c}\text { Less } \\
\text { than } \\
\text { once per } \\
\text { month }\end{array}$ & $\begin{array}{c}1-3 \\
\text { times } \\
\text { per } \\
\text { month }\end{array}$ & $\begin{array}{c}1-3 \\
\text { times } \\
\text { per } \\
\text { week }\end{array}$ & $\begin{array}{l}4 \text { times } \\
\text { per } \\
\text { week or } \\
\text { more }\end{array}$ \\
\hline \multicolumn{6}{|l|}{$\begin{array}{l}\text { Hang out at a friend's home with no adult } \\
\text { present. }\end{array}$} \\
\hline \multicolumn{6}{|l|}{ Hang out with friends in a local parking lot. } \\
\hline \multicolumn{6}{|l|}{$\begin{array}{l}\text { Hang out with friends in a field or wooded } \\
\text { area. }\end{array}$} \\
\hline \multicolumn{6}{|l|}{$\begin{array}{l}\text { Hang out with friends in a local mall, } \\
\text { shopping center, or stores downtown. }\end{array}$} \\
\hline \multicolumn{6}{|l|}{$\begin{array}{l}\text { Hang out with friends at a nearby school } \\
\text { when the school is closed. }\end{array}$} \\
\hline $\begin{array}{l}\text { Hang out with friends in an abandoned } \\
\text { building or empty house. }\end{array}$ & & & & & \\
\hline
\end{tabular}


Hang out with friends at a party where alcohol or drugs are.

We are interested in how you feel about the following statements. Read each statement carefully. Indicate how you feel about each statement.

\begin{tabular}{|c|c|c|c|c|c|c|c|}
\hline & $\begin{array}{c}\text { Very } \\
\text { Strongl } \\
\mathbf{y} \\
\text { Disagre } \\
\mathbf{e}\end{array}$ & $\begin{array}{l}\text { Strongl } \\
\text { y } \\
\text { Disagre } \\
\text { e }\end{array}$ & $\begin{array}{l}\text { Mildly } \\
\text { Disagre } \\
\quad \text { e }\end{array}$ & Neutral & $\begin{array}{l}\text { Mildly } \\
\text { Agree }\end{array}$ & $\begin{array}{l}\text { Strongl } \\
\text { y Agree }\end{array}$ & $\begin{array}{l}\text { Very } \\
\text { Strongl } \\
\text { y Agree }\end{array}$ \\
\hline $\begin{array}{l}\text { There is a special } \\
\text { person who is around } \\
\text { when I am in need. }\end{array}$ & & & & & & & \\
\hline $\begin{array}{l}\text { There is a special } \\
\text { person with whom I } \\
\text { can share my joys and } \\
\text { sorrows. }\end{array}$ & & & & & & & \\
\hline $\begin{array}{l}\text { My family really tries } \\
\text { to help me. }\end{array}$ & & & & & & & \\
\hline $\begin{array}{l}\text { I get the emotional help } \\
\text { and support I need from } \\
\text { my family. }\end{array}$ & & & & & & & \\
\hline $\begin{array}{l}\text { I have a special person } \\
\text { who is a real source of } \\
\text { comfort to me. }\end{array}$ & & & & & & & \\
\hline $\begin{array}{l}\text { My friends really try to } \\
\text { help me. }\end{array}$ & & & & & & & \\
\hline $\begin{array}{l}\text { I can count on my } \\
\text { friends when things go } \\
\text { wrong. }\end{array}$ & & & & & & & \\
\hline $\begin{array}{l}\text { I can talk about my } \\
\text { problems with my } \\
\text { family. }\end{array}$ & & & & & & & \\
\hline $\begin{array}{l}\text { I have friends with } \\
\text { whom I can share my } \\
\text { joys and sorrows. }\end{array}$ & & & & & & & \\
\hline $\begin{array}{l}\text { There is a special } \\
\text { person in my life who } \\
\text { cares about my } \\
\text { feelings. }\end{array}$ & & & & & & & \\
\hline $\begin{array}{l}\text { My family is willing to } \\
\text { help me make }\end{array}$ & & & & & & & \\
\hline
\end{tabular}




\begin{tabular}{|l|l|l|l|l|l|l|l|}
\hline decisions. & & & & & & & \\
\hline I can talk about my & & & & & & & \\
problems with my & & & & & & & \\
friends. & & & & & & & \\
\hline
\end{tabular}


Please read each of the following items carefully, thinking about how it relates to your life, and then indicate how true it is for you.

\begin{tabular}{|c|c|c|c|c|c|c|c|}
\hline & $\begin{array}{c}1 \\
\text { Not } \\
\text { at all } \\
\text { true }\end{array}$ & 2 & 3 & $\begin{array}{c}4 \\
\text { Somewha } \\
\text { t true }\end{array}$ & 5 & 6 & $\begin{array}{c}7 \\
\text { Very } \\
\text { true }\end{array}$ \\
\hline $\begin{array}{l}\text { I feel like I am free to decide for myself } \\
\text { how to live my life. }\end{array}$ & & & & & & & \\
\hline I really like the people I interact with. & & & & & & & \\
\hline Often, I do not feel very competent. & & & & & & & \\
\hline I feel pressured in my life. & & & & & & & \\
\hline $\begin{array}{l}\text { People I know tell me I am good at what I } \\
\text { do. }\end{array}$ & & & & & & & \\
\hline $\begin{array}{l}\text { I get along with people I come into } \\
\text { contact with. }\end{array}$ & & & & & & & \\
\hline $\begin{array}{l}\text { I pretty much keep to myself and don't } \\
\text { have a lot of social contacts. }\end{array}$ & & & & & & & \\
\hline $\begin{array}{l}\text { I generally feel free to express my ideas } \\
\text { and opinions. }\end{array}$ & & & & & & & \\
\hline $\begin{array}{l}\text { I consider the people I regularly interact } \\
\text { with to be my friends. }\end{array}$ & & & & & & & \\
\hline $\begin{array}{l}\text { I have been able to learn interesting new } \\
\text { skills recently. }\end{array}$ & & & & & & & \\
\hline $\begin{array}{l}\text { In my daily life, I frequently have to do } \\
\text { what I am told. }\end{array}$ & & & & & & & \\
\hline People in my life care about me. & & & & & & & \\
\hline $\begin{array}{l}\text { Most days I feel a sense of } \\
\text { accomplishment from what I do. }\end{array}$ & & & & & & & \\
\hline $\begin{array}{l}\text { People I interact with on a daily basis tend } \\
\text { to take my feelings into consideration. }\end{array}$ & & & & & & & \\
\hline $\begin{array}{l}\text { In my life I do not get much of a chance to } \\
\text { show how capable I am. }\end{array}$ & & & & & & & \\
\hline $\begin{array}{l}\text { There are not many people that I am close } \\
\text { to. }\end{array}$ & & & & & & & \\
\hline $\begin{array}{l}\text { I feel like I can pretty much be myself in } \\
\text { daily situations. }\end{array}$ & & & & & & & \\
\hline $\begin{array}{l}\text { The people I interact with regularly do not } \\
\text { seem to like me much. }\end{array}$ & & & & & & & \\
\hline I often do not feel very capable. & & & & & & & \\
\hline
\end{tabular}




\begin{tabular}{|l|l|l|l|l|l|l|}
\hline $\begin{array}{l}\text { There is not much opportunity for me to } \\
\text { decide for myself how to do things in my } \\
\text { daily life. }\end{array}$ & & & & & & \\
\hline $\begin{array}{l}\text { People are generally pretty friendly } \\
\text { towards me. }\end{array}$ & & & & & & \\
\hline
\end{tabular}

Please read each of the following items carefully, thinking about how it relates to you, and then indicate how much you agree or disagree with each statement.

\begin{tabular}{|c|c|c|c|c|c|}
\hline & $\begin{array}{l}\text { Strongly } \\
\text { Disagree }\end{array}$ & Disagree & $\begin{array}{c}\text { Neither } \\
\text { Agree } \\
\text { nor } \\
\text { Disagree }\end{array}$ & Agree & $\begin{array}{l}\text { Strongly } \\
\text { Agree }\end{array}$ \\
\hline $\begin{array}{l}\text { I have decided on the direction I am going } \\
\text { to follow in my life. }\end{array}$ & & & & & \\
\hline $\begin{array}{l}\text { I have plans for what I am going to do in } \\
\text { the future. }\end{array}$ & & & & & \\
\hline $\begin{array}{l}\text { I know which direction I am going to } \\
\text { follow in my life. }\end{array}$ & & & & & \\
\hline $\begin{array}{l}\text { I have an image about what I am going to } \\
\text { do in the future. }\end{array}$ & & & & & \\
\hline $\begin{array}{l}\text { I have made a choice on what I am going } \\
\text { to do with my life. }\end{array}$ & & & & & \\
\hline $\begin{array}{l}\text { I think actively about different directions I } \\
\text { might take in my life. }\end{array}$ & & & & & \\
\hline $\begin{array}{l}\text { I think about different things I might do in } \\
\text { the future. }\end{array}$ & & & & & \\
\hline $\begin{array}{l}\text { I am considering a number of different } \\
\text { lifestyles that might suit me. }\end{array}$ & & & & & \\
\hline $\begin{array}{l}\text { I think about different goals that I might } \\
\text { pursue. }\end{array}$ & & & & & \\
\hline $\begin{array}{l}\text { I am thinking about different lifestyles } \\
\text { that might be good for me. }\end{array}$ & & & & & \\
\hline $\begin{array}{l}\text { I am doubtful about what I really want to } \\
\text { achieve in life. }\end{array}$ & & & & & \\
\hline $\begin{array}{l}\text { I worry about what I want to do with my } \\
\text { future. }\end{array}$ & & & & & \\
\hline $\begin{array}{l}\text { I keep looking for the direction I want to } \\
\text { take in my life. }\end{array}$ & & & & & \\
\hline $\begin{array}{l}\text { I keep wondering which direction my life } \\
\text { has to take. }\end{array}$ & & & & & \\
\hline It is hard for me to stop thinking about the & & & & & \\
\hline
\end{tabular}




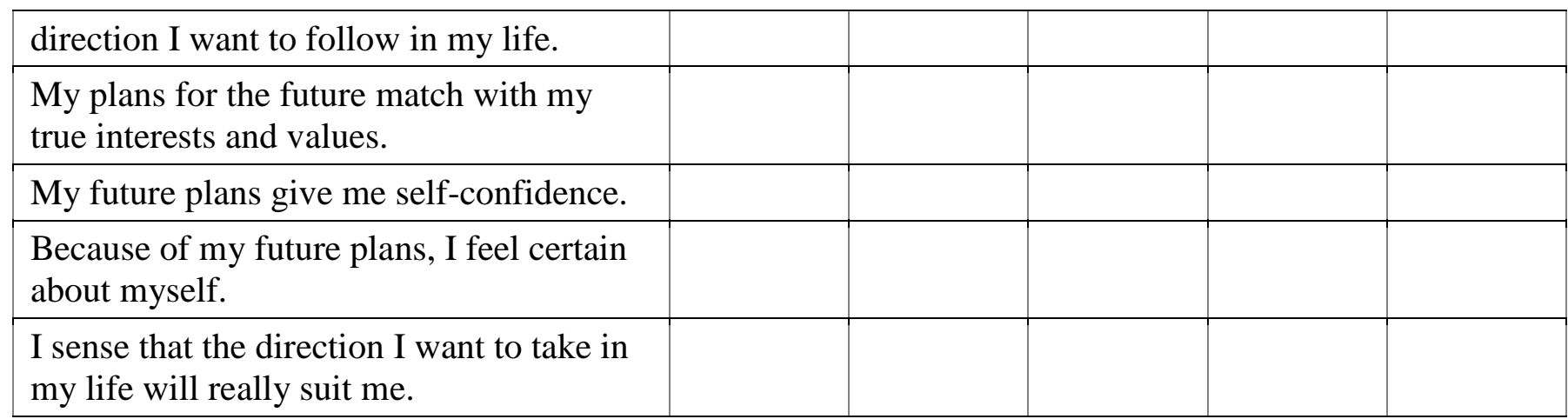

\begin{tabular}{|c|c|c|c|c|c|}
\hline & $\begin{array}{l}\text { Strongly } \\
\text { Disagree }\end{array}$ & Disagree & $\begin{array}{l}\text { Neither } \\
\text { Agree } \\
\text { nor } \\
\text { Disagree }\end{array}$ & Agree & $\begin{array}{l}\text { Strongly } \\
\text { Agree }\end{array}$ \\
\hline $\begin{array}{l}\text { I am sure that my plans for the future are } \\
\text { the right ones for me. }\end{array}$ & & & & & \\
\hline $\begin{array}{l}\text { I think about the future plans I already } \\
\text { made. }\end{array}$ & & & & & \\
\hline $\begin{array}{l}\text { I talk with other people about my plans } \\
\text { the future. }\end{array}$ & & & & & \\
\hline $\begin{array}{l}\text { I think about whether the aims I already } \\
\text { have for my life really suit me. }\end{array}$ & & & & & \\
\hline $\begin{array}{l}\text { I try to find out what other people think } \\
\text { about the specific direction I decided to } \\
\text { take in my life. }\end{array}$ & & & & & \\
\hline $\begin{array}{l}\text { I think about whether my future plans } \\
\text { match with what I really want }\end{array}$ & & & & & \\
\hline
\end{tabular}

The next group of questions asks about tobacco use.

Have you ever tried cigarette smoking, even just one or two puffs?

$\mathrm{O}$ Yes

O No 
During the past 12 months, how often have you smoked cigarettes?

O Never

O 1-2 times

O 3-5 times

O 6-9 times

10-19 times

20-39 times

O 40 times or more

How do you usually get your own cigarettes, chewing tobacco, snuff, or dip?

\begin{tabular}{|c|c|c|c|c|}
\hline & Never & Seldom & Sometimes & Often \\
\hline $\begin{array}{l}\text { I buy them in a store such as a } \\
\text { convenience store, supermarket, } \\
\text { discount store, or gas station. }\end{array}$ & & & & \\
\hline I buy them from a vending machine & & & & \\
\hline $\begin{array}{l}\text { I give someone else money to buy } \\
\text { them for me. }\end{array}$ & & & & \\
\hline $\begin{array}{l}\text { I borrow (or bum) them from } \\
\text { someone else. }\end{array}$ & & & & \\
\hline A family member gives them to me & & & & \\
\hline $\begin{array}{l}\text { A person } 18 \text { years or older who isn' } \\
\text { in my family gives them to me. }\end{array}$ & & & & \\
\hline $\begin{array}{l}\text { I take them from a store without } \\
\text { paying for them. }\end{array}$ & & & & \\
\hline $\begin{array}{l}\text { I take them from a family member } \\
\text { without them knowing. }\end{array}$ & & & & \\
\hline I get them in some other way. & & & & \\
\hline
\end{tabular}

During your lifetime, how often have you used chewing tobacco, snuff, or dip, such as Redman, Levi Garrett, Beechnut, Skoal, Skoal Bandits, or Copenhagen?

O Never

O 1-2 times

O 3-5 times

O 6-9 times

O 10-19 times

O 20-39 times

O 40 times or more 
During the past 30 days, how often have you used chewing tobacco, snuff, or dip, such as Redman, Levi Garrett, Beechnut, Skoal, Skoal Bandits, or Copenhagen?

O Never

O 1-2 times

3-5 times

O 6-9 times

O 10-19 times

20-39 times

O 40 times or more

The next group of questions asks about drinking alcohol. This includes drinking beer, wine, wine coolers, and liquor such as rum, gin, vodka, or whiskey. For these questions, drinking alcohol does not include drinking a few sips of wine for religious purposes.

Have you ever had a drink of alcohol, other than a few sips?

O Yes

O No

During the last 12 months, how often have you had a drink of alcohol (including; beer, wine, wine coolers, and liquor such as rum, gin, vodka, or whiskey) other than a few sips?

O Never

O 1-2 times

3-5 times

O $6-9$ times

O 10-19 times

20-39 times

O 40 times or more

During the last 30 days, how often have you had a drink of alcohol (including; beer, wine, wine coolers, and liquor such as rum, gin, vodka, or whiskey) other than a few sips?

$O$ Never

1-2 times

O $3-5$ times

O 6-9 times

O 10-19 times

20-39 times

O 40 times or more

Have you ever been drunk from drinking alcohol?

$\mathrm{O}$ Yes

O No 
During the past 12 months, how often have you been drunk?

O Never

O 1-2 times

O 3-5 times

O 6-9 times

10-19 times

20-39 times

O 40 times or more 


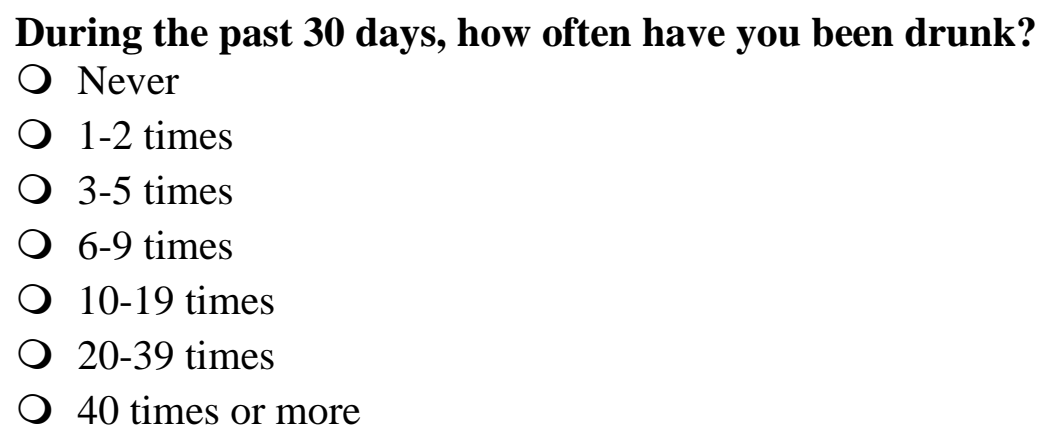

How do you usually get the alcohol you drink?

\begin{tabular}{|c|c|c|c|c|}
\hline & Never & Seldom & Sometimes & Often \\
\hline $\begin{array}{l}\text { I buy them in a store such as a } \\
\text { convenience store, supermarket, } \\
\text { discount store, or gas station. }\end{array}$ & & & & \\
\hline $\begin{array}{l}\text { I give someone else money to buy them } \\
\text { for me. }\end{array}$ & & & & \\
\hline A family member gives them to me. & & & & \\
\hline $\begin{array}{l}\text { A person } 18 \text { years or older who isn't in } \\
\text { my family gives them to me. }\end{array}$ & & & & \\
\hline $\begin{array}{l}\text { I take them from a store without paying } \\
\text { for them. }\end{array}$ & & & & \\
\hline $\begin{array}{l}\text { I take them from a family member } \\
\text { without them knowing. }\end{array}$ & & & & \\
\hline I get them in some other way. & & & & \\
\hline
\end{tabular}

In which places do you drink alcohol?

\begin{tabular}{|l|l|l|l|l|}
\hline In your home. & Never & Seldom & Sometimes & Often \\
\hline $\begin{array}{l}\text { In the home of a family member you } \\
\text { don't live with (such as an aunt, uncle, } \\
\text { grandparent). }\end{array}$ & & & & \\
\hline At your friends home. & & & & \\
\hline In a park or other public area. & & & & \\
\hline In a parking lot of a local business. & & & & \\
\hline In the woods or outdoors & & & & \\
\hline In a bar or club. & & & & \\
\hline At a school dance. & & & & \\
\hline At a youth club/center. & & & & \\
\hline
\end{tabular}


I drink alcohol at some other place.

The next group of questions asks about drug use.

In your lifetime, have you ever used the following drugs or substances?

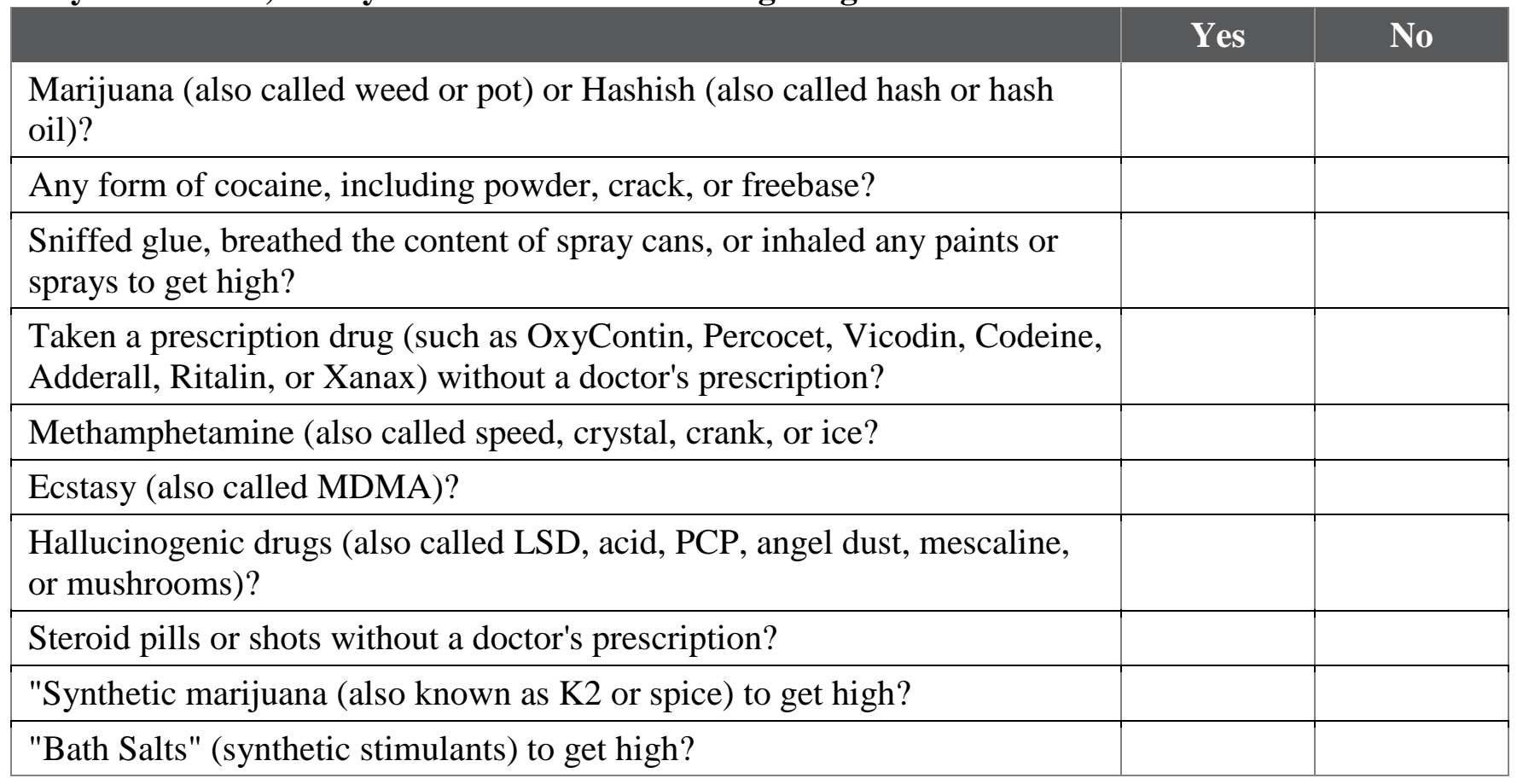

How many times have you used the following drugs or substances in the past 12 months?

\begin{tabular}{|c|c|c|c|c|c|c|c|}
\hline & $\begin{array}{c}0 \\
\text { time } \\
S\end{array}$ & $\begin{array}{c}1-2 \\
\text { time } \\
S\end{array}$ & $\begin{array}{c}3-5 \\
\text { time } \\
S\end{array}$ & $\begin{array}{c}6-9 \\
\text { time } \\
S\end{array}$ & $\begin{array}{l}10- \\
19 \\
\text { time } \\
S\end{array}$ & $\begin{array}{l}20- \\
39 \\
\text { time } \\
s\end{array}$ & $\begin{array}{l}40 \text { or } \\
\text { more } \\
\text { time } \\
s\end{array}$ \\
\hline $\begin{array}{l}\text { Marijuana (also called weed or pot) or Hashish } \\
\text { (also called hash or hash oil)? }\end{array}$ & & & & & & & \\
\hline $\begin{array}{l}\text { Any form of cocaine, including powder, crack, } \\
\text { or freebase? }\end{array}$ & & & & & & & \\
\hline $\begin{array}{l}\text { Sniffed glue, breathed the content of spray cans } \\
\text { or inhaled any paints or sprays to get high? }\end{array}$ & & & & & & & \\
\hline $\begin{array}{l}\text { Taken a prescription drug (such as OxyContin, } \\
\text { Percocet, Vicodin, Codeine, Adderall, Ritalin, } \\
\text { or Xanax) without a doctor's prescription? }\end{array}$ & & & & & & & \\
\hline $\begin{array}{l}\text { Methamphetamine (also called speed, crystal, } \\
\text { crank, or ice? }\end{array}$ & & & & & & & \\
\hline Ecstasy (also called MDMA)? & & & & & & & \\
\hline
\end{tabular}




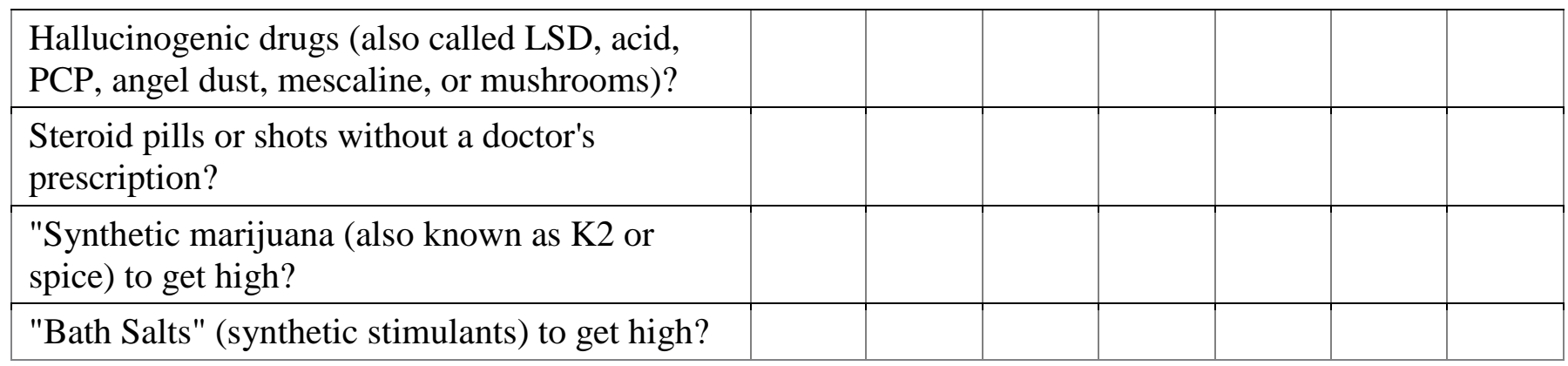

During the past 7 days how many times did you drink a can, bottle, or glass of caffeinated energy drinks such as Monster, Red Bull, XL, Full Throttle, or RockStar?

I did not drink caffeinated energy drinks during the past 7 days

○ 1 to 3 times.

O 4 to 6 times.

O 1 time per day.

2 times per day.

O 3 times per day.

4 or more times per day.

During the past 7 days, how many times did you drink a can, bottle, or glass, of Coke, Diet Coke, Coke Zero, Pepsi, Diet Pepsi, Pepsi Free, Mountain Dew, Diet Mountain Dew, Dr. Pepper, or Diet Dr. Pepper?

I did not drink those drinks during the past 7 days.

O 1 to 3 times.

O 4 to 6 times.

O 1 time per day.

O 2 times per day.

O 3 times per day.

4 or more times per day.

The next group of questions asks about sex.

Have you ever had sexual intercourse?

O Yes

No 
How old were you when you had sexual intercourse for the first time?

I have never had sexual intercourse.

O 11 years old or younger.

O 12 years old.

O 13 years old.

14 years old.

O 15 years old.

O 16 years old.

O 17 years old.

O 18 years old.

O 19 years old.

O 20 years or older.

During your lifetime, with how many people have you had sexual intercourse?

I have never had sexual intercourse.

O 1 person

O 2 people

O 3 people

O 4 people

O 5 people

6 or more people

Did you drink alcohol or use drugs before you had sexual intercourse the last time?

I have never had sexual intercourse.

Y Yes

O No

The last time you had sexual intercourse, did you or your partner use a condom?

I have never had sexual intercourse.

O Yes

O No 
The last time you had sexual intercourse, what method did you or your partner use to prevent pregnancy?

I have never had sexual intercourse.

$\square$ No method was used to prevent pregnancy.

$\square$ Birth control pills.

$\square$ Condoms.

$\square$ Other

Thinking about the type of unmarried girl your age who gets pregnant:

\begin{tabular}{|l|l|l|l|l|}
\hline How cool are they? & Not at all & A little bit & Pretty much & Very much \\
\hline How popular are they? & & & & \\
\hline How smart are they? & & & & \\
\hline $\begin{array}{l}\text { How dull or boring are } \\
\text { they? }\end{array}$ & & & & \\
\hline How attractive are they? & & & & \\
\hline
\end{tabular}

Thinking about the type of unmarried boy your age who gets someone pregnant:

\begin{tabular}{|l|l|l|l|l|}
\hline How cool are they? & Not at all & A little bit & Pretty much & Very much \\
\hline How popular are they? & & & & \\
\hline How smart are they? & & & & \\
\hline $\begin{array}{l}\text { How dull or boring are } \\
\text { they? }\end{array}$ & & & & \\
\hline How attractive are they? & & & & \\
\hline
\end{tabular}

If you had sex in the next year do you think you/your partner would:

\begin{tabular}{|l|l|l|l|l|l|}
\hline & $\begin{array}{c}\text { Definitely } \\
\text { not }\end{array}$ & Maybe not & Neutral & Maybe Yes & $\begin{array}{c}\text { Definitely } \\
\text { Yes }\end{array}$ \\
\hline Use a condom (rubber)? & & & & & \\
\hline Use the pill? & & & & & \\
\hline
\end{tabular}


Have you ever become pregnant (girl) or gotten someone pregnant (boy)?

O Yes

No

How good do you think you are at school work, compared to the other people your age?

Excellent, I am probably one of the best.

Well above average

Above average

Average

O Below Average

Well Below Average

Poor, I am probably one of the worst.

How much time do you usually spend on homework every day?

I never do any homework.

$O$ Less than half an hour

About half an hour

O About one hour

O About two hours

About three hours

About four hours

More than four hours

What were your FINAL grades LAST year?

Mathematics:

$\mathrm{O} A$

O B

$\mathrm{O}$

$\mathrm{O} \mathrm{D}$

$\mathrm{OF}$

English:

O A

O B

O C

O D

$\mathrm{O} F$ 
How many days have you been absent from school during the last 30 days?

\begin{tabular}{|l|l|l|l|l|l|l|}
\hline & None & $\mathbf{1}$ day & $\mathbf{2}$ days & $\mathbf{3 - 4}$ days & $\mathbf{5 - 6}$ days & $\begin{array}{c}\mathbf{7} \text { days or } \\
\text { more }\end{array}$ \\
\hline Because of illness & & & & & & \\
\hline $\begin{array}{l}\text { Because you "skipped" } \\
\text { or "cut" classes }\end{array}$ & & & & & & \\
\hline For other reasons & & & & & & \\
\hline
\end{tabular}

How well do the following statements apply to you?

\begin{tabular}{|c|c|c|c|c|c|}
\hline & $\begin{array}{c}\text { Applies } \\
\text { almost } \\
\text { always to } \\
\text { me }\end{array}$ & $\begin{array}{c}\text { Applies } \\
\text { often to me }\end{array}$ & $\begin{array}{l}\text { Applies } \\
\text { sometimes } \\
\text { to me }\end{array}$ & $\begin{array}{c}\text { Applies } \\
\text { seldom to } \\
\text { me }\end{array}$ & $\begin{array}{c}\text { Almost } \\
\text { never } \\
\text { applies to } \\
\text { me }\end{array}$ \\
\hline $\begin{array}{l}\text { I find the school } \\
\text { studies pointless }\end{array}$ & & & & & \\
\hline $\begin{array}{l}\text { I am bored with } \\
\text { the studies. }\end{array}$ & & & & & \\
\hline $\begin{array}{l}\text { I feel I do not put } \\
\text { enough effort into } \\
\text { studies. }\end{array}$ & & & & & \\
\hline $\begin{array}{l}\text { I want to quit } \\
\text { school. }\end{array}$ & & & & & \\
\hline $\begin{array}{l}\text { I want to change } \\
\text { schools. }\end{array}$ & & & & & \\
\hline
\end{tabular}

You have finished the survey. Please put it back in the envelope and hand it to the teacher. Thank you! 


\section{Appendix D: Additional Tables and Figures}

Table D1. Descriptives and Demographics table.

\begin{tabular}{|c|c|c|c|c|c|}
\hline Variable & $N$ & $M$ & $S D$ & \multicolumn{2}{|c|}{ Range } \\
\hline$\overline{\text { Gender }}$ & 1124 & 1.51 & .50 & $1.00-$ & 2.00 \\
\hline Age & 1119 & 12.54 & .97 & 11.00 & 15.00 \\
\hline Maternal Education & 1037 & 2.75 & 2.31 & $1.00-$ & 9.00 \\
\hline SCsub1 & 1103 & 3.51 & 1.00 & $1.00-$ & 5.00 \\
\hline SCsub2 & 1106 & 3.74 & .99 & $1.00-$ & 5.00 \\
\hline SCsub3 & 1093 & 3.82 & .96 & $1.00-$ & 5.00 \\
\hline SCsub4 & 1089 & 3.96 & .99 & $1.00-$ & 5.00 \\
\hline SCsub5 & 1094 & 4.02 & .91 & $1.00-$ & 5.00 \\
\hline SCsub6 & 1085 & 3.06 & 1.15 & $1.00-$ & 5.00 \\
\hline SCsub7 & 1093 & 2.94 & 1.09 & $1.00-$ & 5.00 \\
\hline SCsub8 & 1090 & 3.27 & 1.19 & $1.00-$ & 5.00 \\
\hline SCsub9 & 1098 & 3.56 & 1.09 & $1.00-$ & 5.00 \\
\hline SCsub10 & 1097 & 2.98 & 1.23 & $1.00-$ & 5.00 \\
\hline Autonomy & 1068 & 4.42 & .98 & $1.00-$ & 7.00 \\
\hline Competency & 1064 & 4.94 & 1.07 & $1.00-$ & 7.00 \\
\hline Relatedness & 1070 & 5.26 & 1.13 & $1.00-$ & 7.00 \\
\hline Commitment Make & 1025 & 3.85 & .95 & $1.00-$ & 5.00 \\
\hline Exploration Breadth & 1006 & 3.79 & .93 & $1.00-$ & 5.00 \\
\hline Rumination & 994 & 3.15 & 1.02 & $1.00-$ & 5.00 \\
\hline Committed & 1003 & 3.86 & .91 & $1.00-$ & 5.00 \\
\hline Exploration Depth & 987 & 3.55 & .92 & $1.00-$ & 5.00 \\
\hline Achievement & 997 & 2.11 & .90 & $1.00-$ & 5.67 \\
\hline Substance Use Count & 1130 & .89 & 1.70 & $.00-$ & 9.00 \\
\hline Sexual Risk Count & 1130 & .37 & .74 & $.00-$ & 4.00 \\
\hline
\end{tabular}

Note: - low value means high achievement. 
Table D2. Bivariate Correlations of Study Variables.

\begin{tabular}{|c|c|c|c|c|c|c|c|c|c|c|c|c|}
\hline Variable & 1 & 2 & 3 & 4 & 5 & 6 & 7 & 8 & 9 & 10 & 11 & 12 \\
\hline 1 Gender & 1.00 & & & & & & & & & & & \\
\hline 2 Household & $-.07 *$ & 1.00 & & & & & & & & & & \\
\hline 3 Maternal Ed & $.08 * *$ & $-.06^{*}$ & 1.00 & & & & & & & & & \\
\hline 4 Autonomy & .03 & $.09^{* *}$ & -.02 & 1.00 & & & & & & & & \\
\hline 5 Competence & .02 & $.13^{* *}$ & -.03 & $.59^{* *}$ & 1.00 & & & & & & & \\
\hline 6 Relatedness & .02 & $.07^{*}$ & -.01 & $.61^{* *}$ & $.68^{* *}$ & 1.00 & & & & & & \\
\hline 7 School Climate 1 & .01 & $.08^{* * *}$ & $-.07^{*}$ & $.38^{* *}$ & $.39^{* *}$ & $.43^{* *}$ & 1.00 & & & & & \\
\hline 8 School Climate 2 & -.02 & $.07^{*}$ & -.05 & $.28^{* *}$ & $.30^{* *}$ & $.36^{* *}$ & $.72^{* *}$ & 1.00 & & & & \\
\hline 9 School Climate 3 & .01 & $.06^{*}$ & $-.07^{*}$ & $.36^{* *}$ & $.37^{* *}$ & $.39^{* *}$ & $.71^{* *}$ & $.75^{* *}$ & 1.00 & & & \\
\hline 10 School Climate 4 & .06 & .04 & -.03 & $.23^{* *}$ & $.28^{* *}$ & $.31^{* *}$ & $.52^{* *}$ & $.57^{* *}$ & $.57^{* *}$ & 1.00 & & \\
\hline 11 School Climate 5 & .00 & $.10^{* *}$ & -.05 & $.34^{* *}$ & $.36^{* *}$ & $.38^{* *}$ & $.64^{* *}$ & $.62^{* *}$ & $.65^{* *}$ & $.56^{* *}$ & 1.00 & \\
\hline 12 School Climate 6 & .02 & $.10^{* *}$ & -.01 & $.28^{* *}$ & $.32^{* *}$ & $.30^{* *}$ & $.47^{* *}$ & $.40^{* *}$ & $.41^{* *}$ & $.29^{* * *}$ & $.38^{* *}$ & 1.00 \\
\hline 13 School Climate 7 & .03 & $.08^{* *}$ & -.04 & $.30^{* *}$ & $.34^{* *}$ & $.23^{* *}$ & $.64^{* *}$ & $.60^{* *}$ & $.58^{* *}$ & $.55^{* *}$ & $.55^{* *}$ & $.50^{* *}$ \\
\hline 14 School Climate 8 & $-.07 *$ & .01 & -.04 & $.20^{* *}$ & $.26^{* *}$ & $.19^{* *}$ & $.27^{* *}$ & $.29^{* *}$ & $.34^{* *}$ & $.19^{* *}$ & $.23^{* *}$ & $.09^{* *}$ \\
\hline 15 School Climate 9 & -.01 & .03 & $-.08^{*}$ & $.39^{* *}$ & $.37^{* *}$ & $.40^{* *}$ & $.57^{* *}$ & $.52^{* *}$ & $.54^{* *}$ & $.49^{* *}$ & $.53^{* *}$ & $.40^{* *}$ \\
\hline 16 School Climate 10 & .02 & .05 & -.01 & $.29^{* *}$ & $.29^{* *}$ & $.24^{* *}$ & $.46^{* *}$ & $.39^{* *}$ & $.42^{* *}$ & $.36^{* *}$ & $.48^{* *}$ & $.37^{* *}$ \\
\hline 17 Commit Make & .05 & .05 & .01 & $.29^{* *}$ & $.30^{* *}$ & $.34^{* *}$ & $.25^{* *}$ & $.24^{* *}$ & $.26^{* *}$ & $.24^{* *}$ & $.30^{* *}$ & $.24^{* *}$ \\
\hline 18 Explore Breadth & .05 & .01 & -.02 & $.32^{* *}$ & $.32^{* *}$ & $.37^{* *}$ & $.33^{* *}$ & $.32^{* *}$ & $.31^{* *}$ & $.26^{* *}$ & $.34^{* * *}$ & $.25^{* *}$ \\
\hline 19 Rumination & -.01 & .05 & -.02 & $.12^{* *}$ & $.13^{* *}$ & $.12^{* *}$ & -.05 & -.04 & -.03 & -.04 & -.03 & -.02 \\
\hline 20 Committed & .03 & .03 & .00 & $.40^{* *}$ & $.39^{* *}$ & $.43^{* *}$ & $.34^{* *}$ & $.32^{* *}$ & $.33^{* *}$ & $.30^{* *}$ & $.36^{* *}$ & $.27^{* *}$ \\
\hline 21 Explore Depth & .03 & .00 & .02 & $.27^{* *}$ & $.26^{* *}$ & $.31^{* * *}$ & $.31^{* * *}$ & $.28^{* *}$ & $.25^{* *}$ & $.27^{* *}$ & $.29^{* * *}$ & $.26^{* *}$ \\
\hline 22 Substance & $-.08 * *$ & $-.12^{* *}$ & .04 & $-.15^{* *}$ & $-.19^{* *}$ & $-.19^{* *}$ & $-.22^{* *}$ & $-.22^{* *}$ & $-.22^{* *}$ & $-.18^{* *}$ & $-.25^{* *}$ & $-.16^{* *}$ \\
\hline 23 Sexual Risk & $-.14 * *$ & $-.10^{* *}$ & .02 & $-.09^{* *}$ & $-.16^{* *}$ & $-.15^{* *}$ & $-.15^{* *}$ & $-.16^{* *}$ & $-.17^{* *}$ & $-.14^{* *}$ & $-.17^{* *}$ & $-.10^{* *}$ \\
\hline 24 Achievement & -.04 & $-.11^{* *}$ & -.03 & $-.23^{* *}$ & $-.29^{* *}$ & $-.29^{* *}$ & $-.27^{* *}$ & $-.19^{* *}$ & $-.19^{* *}$ & $-.14^{* *}$ & $-.38^{* *}$ & $-.27^{* *}$ \\
\hline
\end{tabular}




\begin{tabular}{|c|c|c|c|c|c|c|c|c|c|c|c|c|}
\hline \multirow{2}{*}{\multicolumn{13}{|c|}{$\begin{array}{l}\text { Variable } \\
1 \text { Gender }\end{array}$}} \\
\hline & & & & & & & & & & & & \\
\hline \multicolumn{13}{|l|}{2 Household } \\
\hline \multicolumn{13}{|l|}{3 Maternal Ed } \\
\hline \multicolumn{13}{|l|}{4 Autonomy } \\
\hline \multicolumn{13}{|l|}{5 Competence } \\
\hline \multicolumn{13}{|l|}{6 Relatedness } \\
\hline \multicolumn{13}{|l|}{7 School Climate 1} \\
\hline \multicolumn{13}{|l|}{8 School Climate 2} \\
\hline \multicolumn{13}{|l|}{9 School Climate 3} \\
\hline \multicolumn{13}{|l|}{10 School Climate 4} \\
\hline \multicolumn{13}{|l|}{11 School Climate 5} \\
\hline \multicolumn{13}{|l|}{12 School Climate 6} \\
\hline 13 School Climate 7 & 1.00 & & & & & & & & & & & \\
\hline 14 School Climate 8 & $.31^{* *}$ & 1.00 & & & & & & & & & & \\
\hline 15 School Climate 9 & $.54^{* *}$ & $.22^{* *}$ & 1.00 & & & & & & & & & \\
\hline 16 School Climate 10 & $.54^{* *}$ & $.16^{* *}$ & $.39^{* *}$ & 1.00 & & & & & & & & \\
\hline 17 Commit Make & $.23^{* *}$ & $.10^{* *}$ & $.21^{* *}$ & $.19^{* *}$ & 1.00 & & & & & & & \\
\hline 18 Explore Breadth & $.29^{* *}$ & $.16^{* *}$ & $.26^{* *}$ & $.24^{* *}$ & $.61^{* *}$ & 1.00 & & & & & & \\
\hline 19 Rumination & -.06 & .05 & .00 & -.04 & -.06 & $-.33^{* *}$ & 1.00 & & & & & \\
\hline 20 Committed & $.29^{* *}$ & $.16^{* *}$ & $.24^{* *}$ & $.23^{* *}$ & $.76^{* *}$ & $.61^{* *}$ & $-.09^{* *}$ & 1.00 & & & & \\
\hline 21 Explore Depth & $.29^{* * *}$ & $.11^{* *}$ & $.23^{* *}$ & $.24^{* *}$ & $.53^{* *}$ & $.62^{* *}$ & $-.31^{* *}$ & $.65^{* *}$ & 1.00 & & & \\
\hline 22 Substance & $-.16^{* *}$ & -.06 & $-.16^{* *}$ & $-.14^{* *}$ & $-.10^{* *}$ & $-.11^{* *}$ & -.03 & $-.11^{* *}$ & $-.07^{*}$ & 1.00 & & \\
\hline 23 Sexual Risk & $-.12^{* *}$ & $-.07^{*}$ & $-.13^{* *}$ & $-.10^{* * *}$ & -.05 & $-.08^{*}$ & .01 & $-.08^{*}$ & $-.07^{*}$ & $.48^{* *}$ & 1.00 & \\
\hline 24 Achievement & $-.19^{* *}$ & $-.08^{* *}$ & $-.17^{* *}$ & $-.30^{* *}$ & $-.17^{* *}$ & $-.19^{* *}$ & -.06 & $-.20^{* *}$ & $-.13^{* *}$ & $.17^{* *}$ & $.12^{* * *}$ & 1.00 \\
\hline
\end{tabular}


Table D3. Hierarchical regression model; school climate factors on adolescent development.

\begin{tabular}{|c|c|c|c|c|c|c|}
\hline & \multicolumn{3}{|c|}{ Model 1} & \multicolumn{3}{|c|}{ Model 2} \\
\hline Variable & $B$ & $S E B$ & $\beta$ & $B$ & $S E B$ & $\beta$ \\
\hline Race & -.35 & .07 & $-.15 * *$ & -.27 & .06 & $-.12 * *$ \\
\hline Household & .21 & .06 & $.11^{* * *}$ & .15 & .05 & $.08 * *$ \\
\hline Gender & .05 & .06 & .03 & .07 & .05 & .04 \\
\hline Age & .10 & .03 & $.10 * *$ & -.01 & .03 & -.01 \\
\hline SCsub1 & & & & .17 & .04 & $.19 * *$ \\
\hline SCsub2 & & & & -.07 & .04 & -.07 \\
\hline SCsub3 & & & & .09 & .04 & $.09 *$ \\
\hline SCsub4 & & & & .02 & .03 & .02 \\
\hline SCsub5 & & & & .09 & .04 & $.09 *$ \\
\hline SCsub6 & & & & .08 & .03 & $.10 * *$ \\
\hline SCsub7 & & & & -.05 & .04 & -.06 \\
\hline SCsub8 & & & & .10 & .02 & $.13 * *$ \\
\hline SCsub9 & & & & .18 & .03 & $.22 * *$ \\
\hline SCsub10 & & & & .04 & .02 & .05 \\
\hline Adjusted $R^{2}$ & & .04 & & & .32 & \\
\hline$F$ for change $R^{2}$ & & $11.83 * *$ & & & $41.15 * *$ & \\
\hline
\end{tabular}

Note: $* p<.05 . * p<.01$

SCsub1: Positive Student-Teacher Relationship, SCsub2: Order and Discipline, SCsub3:

Positive Student Engagement, SCsub4: School Physical Environment, SCsub5: Academic

Support, SCsub6: Parental Involvement, SCsub7: School Connectedness, SCsub8: Perceived

Exclusion/Privilege, SCsub9: School Social Environment, SCsub10: Academic Satisfaction. 
Table D4. Hierarchical regression model; school climate and adolescent development on identity.

\begin{tabular}{|c|c|c|c|c|c|c|}
\hline \multirow[b]{2}{*}{ Variable } & \multicolumn{3}{|c|}{ Model 1} & \multicolumn{3}{|c|}{ Model 2} \\
\hline & $B$ & $S E B$ & $\beta$ & $B$ & $S E B$ & $\beta$ \\
\hline Race & -.11 & .06 & -.06 & .02 & .06 & .01 \\
\hline Household & .05 & .05 & .03 & -.05 & .05 & -.03 \\
\hline Gender & .05 & .05 & .03 & .03 & .04 & .02 \\
\hline Age & .05 & .03 & $.06 *$ & -.02 & .02 & -.03 \\
\hline SCsub1 & & & & -.02 & .04 & -.03 \\
\hline SCsub2 & & & & .05 & .04 & .07 \\
\hline SCsub3 & & & & -.01 & .04 & -.01 \\
\hline SCsub4 & & & & .05 & .03 & .07 \\
\hline SCsub5 & & & & .10 & .04 & $.11^{*}$ \\
\hline SCsub6 & & & & .08 & .02 & $.12 * *$ \\
\hline SCsub7 & & & & .06 & .03 & .08 \\
\hline SCsub8 & & & & .01 & .02 & .02 \\
\hline SCsub9 & & & & -.06 & .03 & $-.09 *$ \\
\hline SCsub10 & & & & .01 & .02 & .01 \\
\hline Autonomy & & & & .08 & .03 & $.10 * *$ \\
\hline Competency & & & & .03 & .03 & .04 \\
\hline Relatedness & & & & .17 & .03 & $.24 * *$ \\
\hline Adjusted $R^{2}$ & & .005 & & & .26 & \\
\hline$F$ for change $R^{2}$ & & 2.17 & & & $25.80 * *$ & \\
\hline
\end{tabular}

Note: ${ }^{*} p<.05 .{ }^{* *} p<.01$

SCsub1: Positive Student-Teacher Relationship, SCsub2: Order and Discipline, SCsub3:

Positive Student Engagement, SCsub4: School Physical Environment, SCsub5: Academic

Support, SCsub6: Parental Involvement, SCsub7: School Connectedness, SCsub8: Perceived

Exclusion/Privilege, SCsub9: School Social Environment, SCsub10: Academic Satisfaction. 
Table D5. Confirmatory factor analysis of latent variables in the model.

\begin{tabular}{|c|c|}
\hline Variables & $(S E)$ \\
\hline \multicolumn{2}{|l|}{ School Climate } \\
\hline SCsub1 & $1.00(--)$ \\
\hline SCsub2 & $.94(.03)$ \\
\hline SCsub3 & $.94(.03)$ \\
\hline SCsub4 & $.80(.03)$ \\
\hline SCsub5 & $.81(.03)$ \\
\hline SCsub6 & $.71(.04)$ \\
\hline SCsub7 & $.95(.03)$ \\
\hline SCsub8 & $.47(.04)$ \\
\hline SCsub9 & $.86(.03)$ \\
\hline SCsub10 & $.77(.04$ \\
\hline \multicolumn{2}{|l|}{ Basic Psychological Needs Satisfaction } \\
\hline Autonomy & $1.00(---)$ \\
\hline Competency & $1.21(.06)$ \\
\hline Relatedness & $1.32(.05)$ \\
\hline \multicolumn{2}{|l|}{ Identity Development } \\
\hline Commitment Make & $1.00(--)$ \\
\hline Exploration Breadth & $1.04(.05)$ \\
\hline Exploration in Depth & $1.01(.05)$ \\
\hline Committed & $1.07(.04)$ \\
\hline \multicolumn{2}{|c|}{ Note: --- indicates when the standard error was not estimated. } \\
\hline \multicolumn{2}{|c|}{ SCsub1: Positive Student-Teacher Relationship, SCsub2: Order and } \\
\hline \multicolumn{2}{|c|}{ Discipline, SCsub3: Positive Student Engagement, SCsub4: School } \\
\hline \multicolumn{2}{|c|}{ Physical Environment, SCsub5: Academic Support, SCsub6: Parental } \\
\hline \multicolumn{2}{|c|}{ Involvement, SCsub7: School Connectedness, SCsub8: Perceived } \\
\hline \multicolumn{2}{|c|}{ Exclusion/Privilege, SCsub9: School Social Environment, } \\
\hline SCsub10: Academic Satisfaction. & \\
\hline
\end{tabular}


Figure D6. Structural Model on Academic Achievement.

Control Variables:

Gender
Race
Age
Household Configuration
Maternal Education

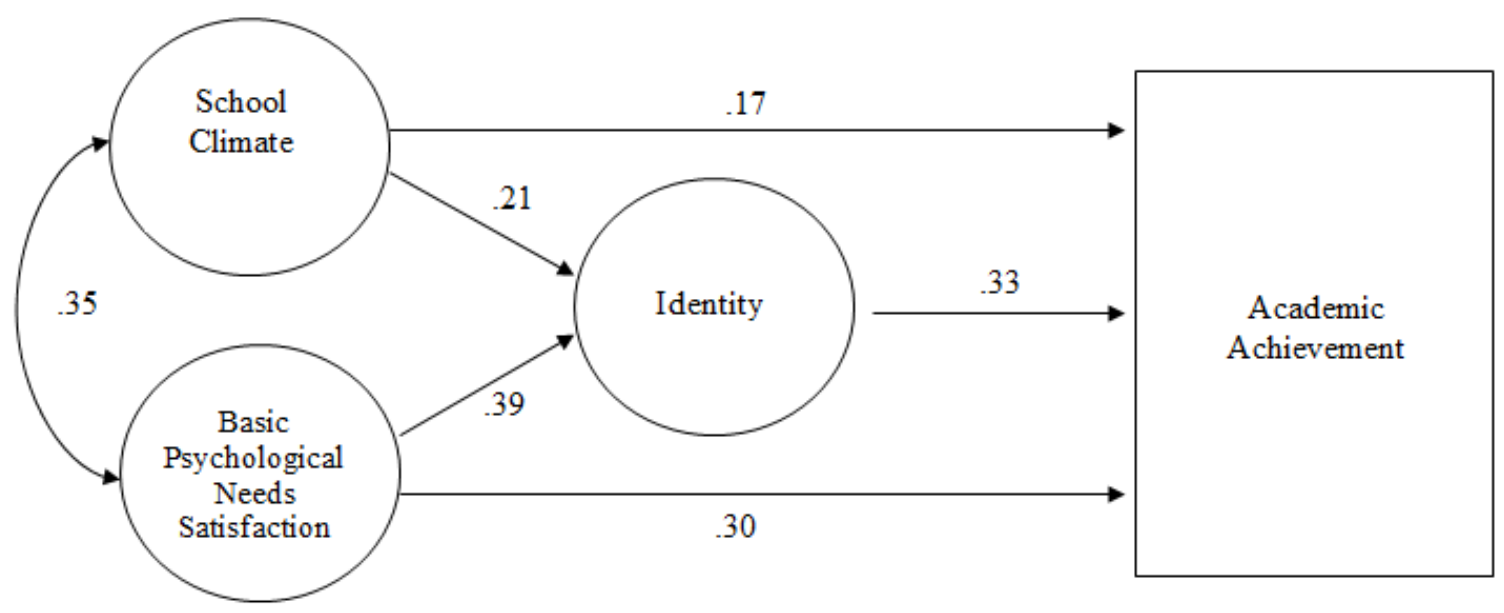


Figure D7. Structural Model on Substance Use.

Control Variables:

Gender
Race
Age
Household Configuration
Maternal Education

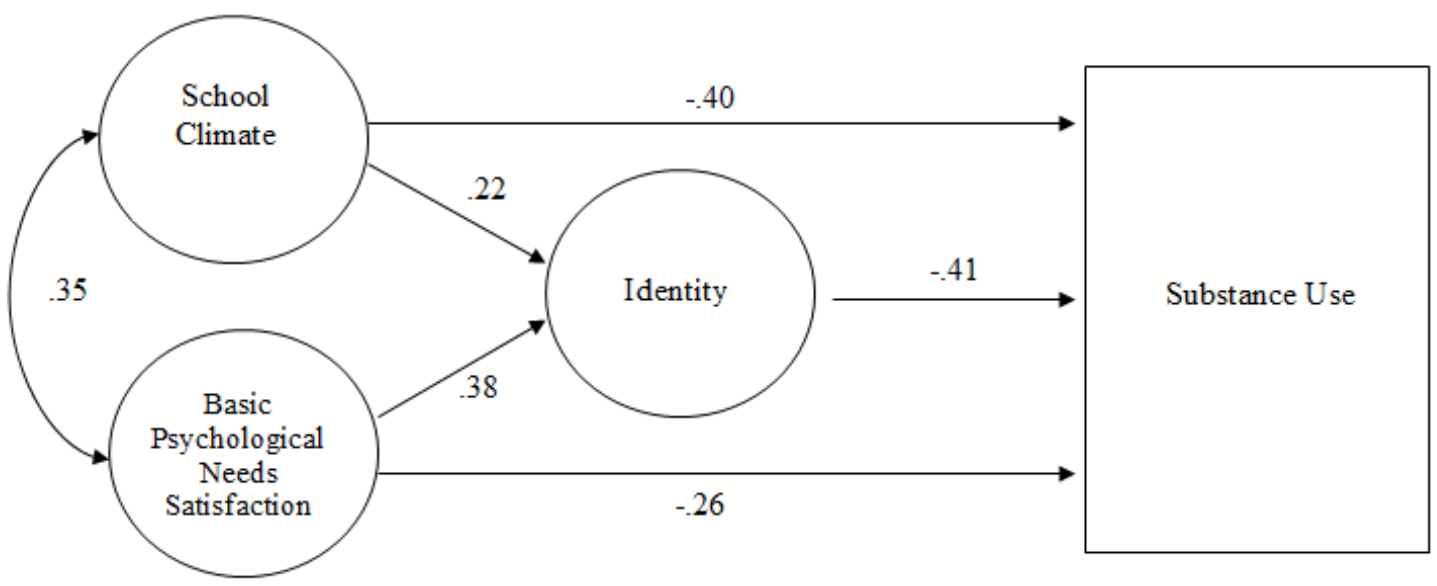


Figure D8. Structural Model on Sexual Risk.

Control Variables:

\begin{tabular}{|l|}
\hline Gender \\
Race \\
Age \\
Household Configuration \\
Maternal Education \\
\hline
\end{tabular}

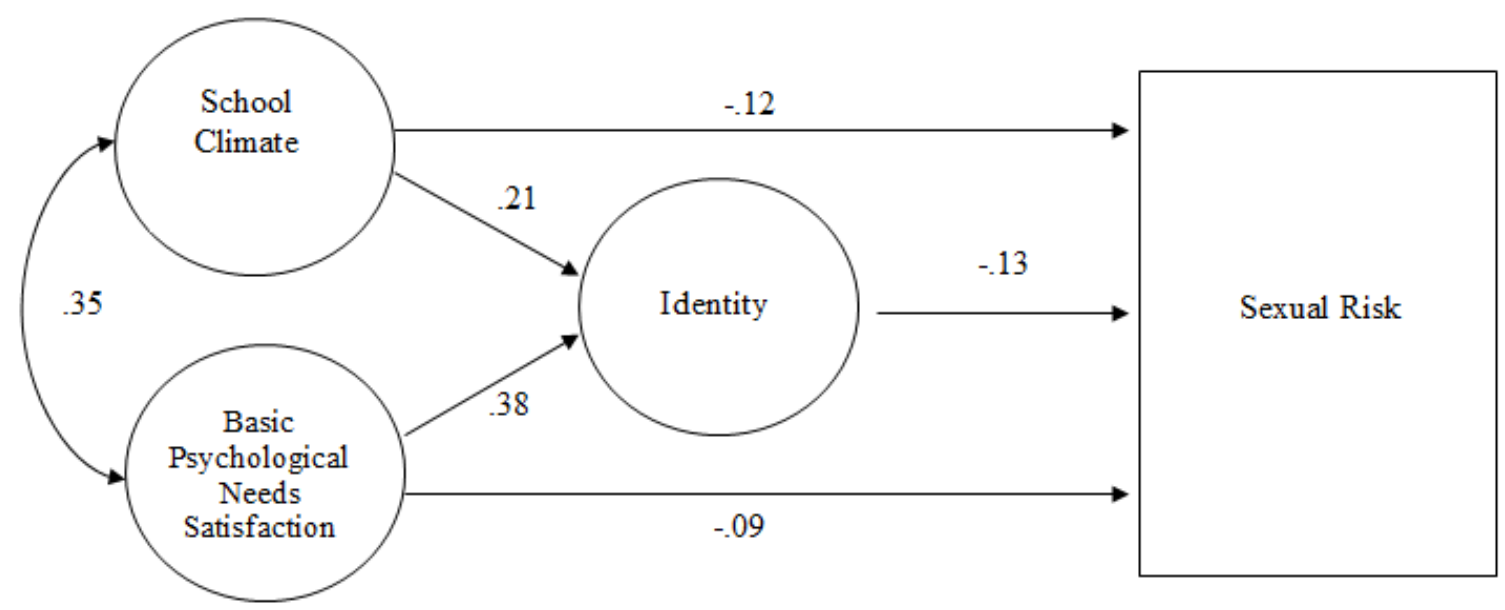




\title{
Curriculum Vitae
}

\author{
MEGAN L. SMITH \\ West Virginia University \\ College of Education and Human Services \\ Dept. of Learning Sciences and Human Development
}

\section{Contact Information:}

521 Junior Avenue

Morgantown, WV 26505

Telephone: (304) 777-7363

Email: megansmith.mls@gmail.com

\section{Education}

Ph.D. Education, Human Development \& Family Studies, 2015

Anticipated Graduation May 2015

West Virginia University

Department of Learning Sciences and Human Development

Emphasis: Adolescent Development, School Environment, Risk \& Protective Factors, Teacher Preparation

Graduate Level California Teaching Credential, 2008

California State University, Chico

Department of Education

Emphasis: Multiple Subjects Teaching K-8 (CLAD)

Emphasis: Single Subject Teaching, English \& Performing Arts K-8 (CLAD)

Bachelor of Arts, 2006

Department of Psychology

University of California, Santa Cruz

Emphasis: Special Populations

Minor: Education

\section{Professional Experience in Higher Education}

\section{West Virginia University, Morgantown, WV}

Program Evaluation and Research Center, Graduate Research Assistant (2013-)

- Advanced Analysis (SEM, Logistic Regression, etc.) Consultation for Faculty and Students at College of Education and Human Services and College of Physical Activity and Sports Sciences

- Grant Preparation and Evaluation

- Program Evaluation 
- Research Proposals, Analysis, and Manuscript development

Applied Psychology Lab (2013- )

- Measurement Analysis and Psychometrics

- Data Analysis and Manuscript development for NIH funded grant projects

Benedum Collaborative, Graduate Teaching/Research Assistant, Accreditation (2012- )

- Taught EDUC 600; Action Research course

- Observation, coordination, feedback for pre-service teachers during field experience

- Communicate and facilitate relationship between K-12 schools and WVU

Adjunct Course Instructor (2012- )

- CDFS 212, Early Childhood Development

- CDFS 412, Adolescent Development

- EDP 613, Statistics 1

\section{Feather River Community College, Quincy, CA}

Upward Bound Instructor (2010-2012)

- Taught for Upward Bound program

- Created meaningful curriculum for first generation college students seeking support to remain on a successful educational path.

\section{University of California, Santa Cruz, CA}

\section{Chancellor's Undergraduate Intern (2004-2006)}

1. Developed a course that examined international issues in conflict resolution and diplomacy for the Chancellor's office.

2. Created the syllabus, goals and focus for the class and led main lectures for 100 college students to expand global awareness.

3. Hired, collaborated with, and trained several teachers for the discussion sections.

Student Lecturer (2003-2005)

4. Taught a seminar using the United Nations as a lens to help college freshmen examine our global community within a greater framework of laws, values, and society.

Program Coordinator, College Nine (2003-2004)

- Improved the existing theme-related programs to meet the needs of a diverse population by collaborating with a student team.

- Thoughtfully considered new ways to incorporate health promotion within program events while working within a budget.

- Awarded a full, one year scholarship as a result of my work in this position.

Barrios Unidos Field Experience, (2003-2004)

- Worked with students ages 5-18 at an after school community center for at-risk Latino youth. 
- Developed community beautification/service projects and assisted with academic tasks.

- Liaised between this community and the Santa Cruz public to foster greater participation in schools and their community.

\section{Professional Experience in K-12 Education}

\section{Quincy Junior Senior High School, Quincy, CA}

Teacher, $7^{\text {th }}-12^{\text {th }}$ Grade Science, Math and Drama (2010-2012)

- Designed \& implemented a research-based program for a new middle "school within a school" model with a team.

- Collaborated with staff, parents and community members to engage in the profession of teaching and create better social and academic environments for kids.

- Raised test scores and sense of self-efficacy in students.

Director/Drama Coach (2010-2012)

- Maintained a budget and directed a cast of 36-45 students aged 12-18.

- Produced, directed, choreographed, and designed a variety of productions including; "Brothers Grimm Spectaculathon," "Pride \& Prejudice," "The Lottery," and "Bye Bye Birdie."

\section{Marsh Junior High School, Chico, CA}

Teacher, English 7, 8 and English Language Development (2009-2010)

- Planned curriculum and assessments employing SDAIE strategies and content standards for English 7, 8 and 3 levels of English Language Development.

- Innovated new strategies, such as our "ELD Newscast" to re-engage and encourage student learning.

- Supported a diverse group of "challenged students" in need of intervention in after school "Success Class."

\section{Pleasant Valley High School, Chico, CA}

Student and Substitute Teacher, English, Psychology, and Drama (2008-2009)

- Planned curriculum and assessments employing SDAIE strategies and content standards for English 7, 8 and 3 levels of English Language Development.

- Innovated new strategies, such as our "ELD Newscast" to re-engage and encourage student learning.

- Supported a diverse group of "challenged students" in need of intervention in after school "Success Class."

\section{Live Oak Elementary School, Chico, CA}

Classroom Connection Tutor (2005)

- Aided in an award winning 'Reading Recovery' program to develop literacy and confidence in struggling elementary students. 
- Kept detailed observations on student developmental progress to maintain learning continuity.

\section{Teaching Experience}

University Courses Taught, Contributed to, and/or Developed

- CDFS 412 Adolescent Development, WVU, Fall 2014

- $\quad$ EDP 614, Statistics 2 (Online), WVU , Fall 2014

- EDP 613 Statistics 1 (Online), West Virginia University, Summer 2014, Spring 2015

- EDUC 600 Teacher as Researcher- Inquiry as Stance, WVU (2012-present)

- EDUC 411 Teacher as Researcher- Inquiry as Stance, WVU (2012-present)

- EDUC 410 Teacher as Researcher- Inquiry as Stance, WVU (2012-present)

- EDUC 312 Teacher as Researcher- Inquiry as Stance, WVU (2012-present)

- EDUC 310 Teacher as Researcher- Inquiry as Stance, WVU (2012-present)

- CDFS 212 Early Childhood Development (Online), WVU (2013)

- International Conflict Resolution \& Diplomacy, UCSC (2004-2006)

- International \& Global perspectives, UCSC (2003-2005)

\section{K-12 Subjects Taught}

- Health, $7^{\text {th }}$ Grade (2010-2012)

- $\quad$ Life Science, $7^{\text {th }}$ Grade (2010-2012)

- Pre-algebra and Algebra, $7^{\text {th }}$ Grade (2010-2012)

- Theater Arts, 9-12 ${ }^{\text {th }}$ Grade (2010-2012)

- English Language Arts 7-11 ${ }^{\text {th }}$ grade (2008-2010)

- Psychology- $12^{\text {th }}$ Grade (2008)

\section{Research}

\section{Peer-Reviewed Manuscripts Accepted for Publication}

Mann, M.J., Smith, M.L., Kristjansson, A.L. \& Haley, P. (In Press). REAL Girls at Chico Junior High: Enhancing Relevance in Clinical Preparation Experiences. In P.B. Howell, J. Carpenter \& J. Jones, Clinical Preparation at the Middle Level: Practices and Possibilities, Charlotte, NC: IAP.

Mathew, S., Georgieva, Z., Smith, M.L., Curtis, R., Moore, L., Chester, A. \& McKendall, S. (in press)"Rural Student Voices to Improve Educational Attainment Oriented Programs" American Association of Behavioral \& Social Sciences Journal. Accepted for publication April 2014.

Mann, M.J., Kristjansson, A.L., Sigfusdottir, I.D., \& Smith, M.L. (2014). Negative Life Events and Early Adolescent Depression, Anger, and Anxiety: Comparing the Relative Vulnerability of Early, Middle, and Late Adolescents. Research in Middle Level Education, 38(2), 1-13.

Mann, M.J., Smith, M.L. \& Kristjansson, A.L. (2014). Improving Academic Self-Efficacy, School Connectedness, and Identity in Struggling Middle School Girls: A Quasi-Experimental, Mixed-Methods Study of the REAL Girls Program. Health Education and Behavior, Accepted for Publication April 2014. 
Mann, M.J. \& Smith, M.L. (January 2013). Promoting Rigor-in-Practice through School SelfEvaluation: A Middle School's Experience with Model Development, Implementation, and Evaluation Using the Model of Student Empowerment for Alternative Middle Schools. Research in Middle Level Education, peer reviewed, accepted for publication on June 2, 2012.

\section{Peer-Reviewed Manuscripts under Review}

Schimmel, C., Curtis, R., Georgieva, Z., \& Smith, M. (Submitted December 2014). Making use of statewide needs assessment: What rural schools need. Journal of School Counseling.

Mann, M.J., Kristjansson, A.L., Sigfusdottir, I.D., \& Smith, M.L. (Submitted July 2013). Assessing the Role of Community, Parent, Peer and School Factors in Adolescent Bullying: Implications for Effective School-Based Intervention. Revised \& resubmitted to the Journal of School Health, March 30, 2014.

Smith, M. L. \& Markstrom, C. A. (Submitted December 2013). Global Identity and Ego Identity Formation in Relation to Global Sources of Influence. Emerging Adulthood.

\section{Peer-Reviewed Manuscripts in Progress}

Curtis, R., Georgieva, Z., Smith, M., Mathew, S., Moore, L. \& Saenz, T. (manuscript). Collaborative logic modeling to plan, evaluate and foster collaborations. Journal of Behavioral and Social Sciences.

\section{Technical Reports}

Curtis, R., Georgieva, Z., \& Smith, M. (2014). 2013 Fall Break: WVU Faculty Perceptions Survey Results. Report commissioned by the West Virginia University Faculty Senate Executive Committee.

Curtis, R., Smith, M. Georgieva, Z., Mathew, S. \& Moore, L. (2014). Year 1 Annual Report (June 15, 2014): Evaluation support for "Integrating health and biology in a science curriculum for Latino preschoolers"

\section{Peer-Reviewed Research Presentations}

Smith, M.L. \& Moilanen, K. (in preparation). Antecedents to Academic Self-esteem in Adolescence. Submitted to the American Psychological Association.

Smith, M.L. (accepted, not presented). Predicting Risk Behavior in Early Adolescence using the Dimensions of Identity Development Scale. Society for Research on Identity Formation.

Smith, M.L. \& Markstrom, C. A. (accepted, not presented). Supporting Identity Development in Schools. Society for Research on Identity Formation. 
Smith, M.L., Georgieva, Z., Curtis, R., \& Schimmel, C. (April 2015). Student Enjoyment and Aspiration in Middle School. Paper presented at the American Education Research Association conference.

Mann, M.J., Kristjansson, A.L. \& Smith, M.L. (November 2014). The Community Engagement Scale. Presented at the American Public Health Association's Annual Conference

Mann, M.J. \& Smith, M.L. (November 2014). The Model of Empowered Student Behavior for Alternative Middle Schools. Presented at the Association for Middle Level Educators' National Conference

Mann, M.J. \& Smith, M.L. (November 2014). Supporting Middle School Students Grieving the Loss of a Parent. Presented at the Association for Middle Level Educators' National Conference

Mann, M.J. \& Smith, M.L. (November 2014). Professional Development Planning for Preservice and Early Career Teachers. Presented at the Association for Middle Level Educators' National Conference

Smith, M.L. \& Mann, M.J. (November 2014). Developmentally Responsive Middle School Educators: Application to Practice. Presented at the Association for Middle Level Educators' National Conference.

Mann, M.J., Kristjansson, A.L. \& Smith, M. L. (March, 2014). Negative life events and early adolescent emotional health: Examining the relative vulnerabilities of younger and older adolescents. Society for Adolescent Research Biennial Conference.

Smith, M.L. \& Mann, M. J. (March 2014). Strong, Capable, and Confident: Evaluating Developmental Intervention Strategies Designed to Promote Resilient Identity in Vulnerable Early Adolescent Girls. Society for Research on Identity Formation.

Curtis, R., Georgieva, Z., Smith, M., Mathew, S., Moore, L. \& Saenz, T. (February 2014). Collaborative logic modeling to plan, evaluate and foster collaborations. American Association of Behavioral and Social Sciences.

Mann, M.J. \& Smith, M.L. (October 2013). What Works with Struggling Middle School Girls: 12 Elements of Effective Intervention Programs. American School Health Association National Conference.

Smith, M. \& Markstrom, C. A. (May 2013). Global Identity and Ego Identity Formation in Relation to Global Sources of Influence. Society for Research on Identity Formation.

Mann, M.J., Kristjansson, A. \& Smith, M. (April 2013). Improving Struggling Middle School Girls' Levels of School Connectedness, Academic Self-Efficacy, and Identity: A Mixed Methods Quasi-Experimental Study of the REAL Girls Program. Society for Public Health Education. 
Smith, M. \& Markstrom, C. A. (April 2013). Global Identity and Ego Identity Formation in Relation to Global Sources of Influence; A Preliminary Study. CEHS Graduate Student Research Forum.

\title{
Grant Proposals Contributed to
}

"Project Launch" Fatherhood Initiative. West Virginia State Department of Education. (In progress)

“Project Aware” (2014-2019) West Virginia State Department of Education. (Total Awarded \$)

"Education Elevators" (2014-2015), Education Alliance- Business and Community for Public Schools, Inc. (Total Awarded \$6,000)

"Americorps on the Frontline for Education" (2012-2015). Education Alliance- Business and Community for Public Schools, Inc. (Total Awarded \$50,000)

"Preschool science evaluation: Integrating health and biology in a science curriculum for Latino preschoolers" (2013-2014). sub-award from University of California, Santa Barbara on National Institutes of Health Award No. R25OD010537-02. (Total Awarded \$10,000)

"Benedum Collaborative impact on student learning and achievement". (2013, \$129,181 not funded).

\author{
Master's Level Action Research Projects Supervised \\ Maria Cerilli, Strategies for Mathematical Reasoning \\ Carrie Dalton, Online Journal Writing \\ Meredith Dorsey,The Impact of Art Creation and Exploration on Student Writing. \\ Megan Long, Small Group Game Stations and Their Impact on Student Learning in Math \\ Ellie McCoy, The Impact of Geography Lessons in History Class \\ Brittany Reilly, Authentic Economics in Second Grade Math Class \\ Katherine Schaer, How Parent Involvement Outside the Classroom Affects Student Achievement \\ Jennifer Sirockman, Students'Attitudes towards Science and Their Textbooks \\ Tara Tyler, Learning in an Electronic Environment
}

\section{Undergraduate Research Assistants Supervised}

Lisa-Marie Barone, B.A. Child Development and Family Studies

Lindsey Fisher, B.A. Child Development and Family Studies

Caitlin Spriggs, B.A. Child Development and Family Studies

Lauren Strauss, B.A. Child Development and Family Studies

Amy Young, B.A. Psychology

\section{Service to the University, College, and Profession}

Faculty Hiring Committee for Department Chair (2014-2015)

Graduate Student Advisory Committee (2014-present)

Student member on the Secondary Data Analysis committee (2013-present) 
Accreditation work for CAEP and NCATE- Data Analysis and Report Prep (2012-present)

Portfolio Review for Benedum Collaborative, West Virginia University (2012-present)

Health, Science \& Technology Academy Summer Camp Educator (2014)

Research Institute Facilitator, Benedum Collaborative, WVU (2012-2014)

Liaison for the Benedum Collaborative (2012-2013)

\section{Honors and Awards}

College of Education and Human Services Research Grant, \$1500, 2015

College and Department Research Travel Award, \$900, 2014

Graduate Researcher Award, CEHS Research Forum, Second place, 2014

Woodrow \& Virginia Bonds Endowed Scholarship, (2013-2015)

Graduate Researcher Award, CEHS Research Forum, Third place, 2013

Honoree, invited speaker for CSU Chico credential graduation ceremony, 2008

Honors in the major; Psychology-UCSC, 2006

College Service Award- College Nine, UCSC 2006

International and Global Perspectives Leadership Recognition- College Nine, UCSC 2006

Language and Culture Distinction- College Nine, UCSC 2006

Chancellor's Undergraduate Internship, International Studies- UCSC 2005 [full scholarship]

\section{Current Professional and Academic Association Memberships}

American School Health Association, American Educational Research Association, Association for Middle Level Educators, National Educators Association, Society for Research on Adolescence, and Society for Research on Identity Formation

- Reagan Curtis, Ph.D.

\section{References}

Director of Program Evaluation \& Research Center

WVCTSI Director of Tracking, Evaluation, and Quality Improvement

Professor of Educational Psychology

Department of Learning Sciences \& Human Development

College of Education \& Human Services

West Virginia University

Allen Hall 507D

Phone: (304)293-2098

Fax: (304)293-9424

Reagan.Curtis@mail.wvu.edu

- Sarah Steele

Program Coordinator; Benedum Collaborative Five-Year Teacher Education Program

West Virginia University

606E Allen Hall, P.O. Box 6122

Morgantown, WV 26506-6122 
Phone: (304) 293-6762

sarah.steel@mail.wvu.edu

- Glenn Harris

CEO, Pacific Executive \& Education Leadership Associates

(Former K-12 Public Schools Superintendent)

PO Box 148, Ninole, HI 96773

Phone: (808) 313-1504

gharris@pacificleadershipassociates.com

- Carol A. Markstrom, Ph.D.

Professor of Child Development and Family Studies (Dissertation Chair)

Department of Learning Sciences \& Human Development

College of Education \& Human Services

West Virginia University

506G Allen Hall, P.O. Box 6122

Morgantown, WV 26506-6122

Phone: (304) 293-3344

carol.markstrom@mail.wvu.edu 